\title{
Van starter tot gevorderde
}

Citation for published version (APA):

Allen, J., Belfi, B., \& Mommers, A. (2016). Van starter tot gevorderde: De loopbaanontwikkeling van hbo'ers in de eerste vijf jaren na afstuderen. ROA. ROA Reports No. 006

https://doi.org/10.26481/umarep.2016006

Document status and date:

Published: 01/01/2016

DOI:

10.26481/umarep.2016006

Document Version:

Publisher's PDF, also known as Version of record

\section{Please check the document version of this publication:}

- A submitted manuscript is the version of the article upon submission and before peer-review. There can be important differences between the submitted version and the official published version of record.

People interested in the research are advised to contact the author for the final version of the publication, or visit the DOI to the publisher's website.

- The final author version and the galley proof are versions of the publication after peer review.

- The final published version features the final layout of the paper including the volume, issue and page numbers.

Link to publication

\footnotetext{
General rights rights.

- You may freely distribute the URL identifying the publication in the public portal. please follow below link for the End User Agreement:

www.umlib.nl/taverne-license

Take down policy

If you believe that this document breaches copyright please contact us at:

repository@maastrichtuniversity.nl

providing details and we will investigate your claim.
}

Copyright and moral rights for the publications made accessible in the public portal are retained by the authors and/or other copyright owners and it is a condition of accessing publications that users recognise and abide by the legal requirements associated with these

- Users may download and print one copy of any publication from the public portal for the purpose of private study or research.

- You may not further distribute the material or use it for any profit-making activity or commercial gain

If the publication is distributed under the terms of Article $25 \mathrm{fa}$ of the Dutch Copyright Act, indicated by the "Taverne" license above, 


\section{VAN STARTER TOT GEVORDERDE De loopbaanontwikkeling van hbo'ers in de eerste vijf jaren na afstuderen}

ROA-R-2016/6

Jim Allen

Barbara Belfi

Ardi Mommers 


\section{Colofon}

(C) Researchcentrum voor Onderwijs en Arbeidsmarkt (ROA). Niets uit deze uitgave mag op enige manier worden verveelvoudigd zonder voorafgaande schriftelijke toestemming van de directeur van het ROA.

\section{Researchcentrum voor Onderwijs en Arbeidsmarkt}

School of Business and Economics

Maastricht University

email: secretary-roa-sbe@maastrichtuniversity.nl

website: www.roa.nl

\section{Vormgeving}

ROA secretariaat, Maastricht

ISBN: 978-90-5321-550-0

december 2016 


\section{INHOUD}

02 Theoretische achtergrond 3

03 Data en methode 7

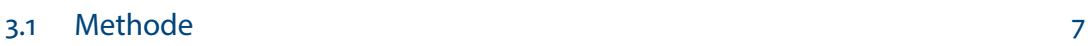

$\begin{array}{lll}3.2 & \text { Bestandskoppelingen } & 7\end{array}$

3.3 Responsgroep en representativiteit 8

$\begin{array}{lll}3.4 & \text { Representativiteit nader beschouwd } & 9\end{array}$

04 Veranderingen in arbeidsmarkt-uitkomsten tussen 2011 en 2015

4.1 Welke maatschappelijke posities bekleden hbo-afgestudeerden 5 jaar na afstuderen?

4.2 Veranderingen in werkloosheid gedurende de eerste 5 jaar na afstuderen

4.3 Veranderingen in aantal werkgevers gedurende de eerste 5 jaar na afstuderen

4.4 Veranderingen in bedrijfssectoren waarin afgestudeerden werkzaam zijn gedurende de eerste 5 jaar na afstuderen

4.5 Veranderingen in beroepsgroepen waarin afgestudeerden werkzaam zijn gedurende de eerste 5 jaar na afstuderen

4.6 Ontwikkelingen in leidinggeven aan medewerkers gedurende de eerste 5 jaar na afstuderen

4.7 Ontwikkelingen in het werkzaam zijn op minimaal hbo-niveau en naar opleidingsrichting tussen 2011 en 2015

4.8 Ontwikkelingen in de competentietekorten en -overschotten van afgestudeerden tussen 2011 en 2015

4.9 Ontwikkelingen in de beoordeling van carrièremogelijkheden tussen 2011 en 2015

4.10 Ontwikkelingen in baantevredenheid tussen 2011 en 2015

4.12 Ontwikkelingen in het werken als zelfstandige tussen 2011 en 2015

4.13 Ontwikkelingen in het hebben van een vaste aanstelling tussen 2011 en 2015

4.14 Ontwikkelingen in bruto uurloon tussen 2011 en 2015 
05 Veranderingen in studie-tevredenheid tussen 2011 en 2015

5.1 Veranderingen in algemene studietevredenheid tussen 2011 en 2015

5.2 Veranderingen in tevredenheid over studie als voorbereiding op verdere loopbaan tussen 2011 en 2015

5.3 Veranderingen in het opnieuw kiezen van de hbo-opleiding tussen 2011 en 2015

06 Discussie en Conclusie

07 literatuur 


\section{SAMENVATTING}

In 2015 is naast de reguliere T+1-meting van de HBO-Monitor, waarbij afgestudeerden één jaar na afstuderen worden benaderd, ook een meting vijf jaar na afstuderen uitgevoerd (T+5-meting). In deze meting zijn afgestudeerden die in 2011 reeds aan de reguliere HBO-Monitor hebben deelgenomen, in 2015 nogmaals benaderd. In dit rapport bespreken we de loopbaanontwikkeling van deze hbo-afgestudeerden gedurende de eerste 5 jaren dat ze zich op de arbeidsmarkt bevinden. De benadering van dezelfde groep personen op twee momenten maakt dit mogelijk. In deze samenvatting, zetten we de belangrijkste uitkomsten van dit onderzoek op een rij:

- Afgestudeerden die in 2011 werkloos waren hebben een veel grotere kans (dan werkenden in 2011) om in 2015 nog steeds werkloos te zijn: 14 procent van hen is in 2015 nog steeds werkloos. Onder werkenden uit 2011 betreft het werkloosheidspercentage in 2015 daarentegen slechts 3 procent.

- Bijna de helft van de werklozen uit 2011 heeft vier jaar later een baan op niveau en in de eigen richting gevonden. Deze groep 'trage starters' heeft dus een snelle inhaalslag gemaakt.

- Baanmobiliteit tussen verschillende werkgevers blijkt het grootst onder afgestudeerden uit de hbo-sector Taal \& Cultuur en het laagst onder afgestudeerden uit de hbo-sectoren Techniek en Landbouw.

- Mobiliteit tussen beroepsgroepen vindt procentueel het vaakst plaats vanuit de 'dienstverlenende beroepen' (het betreft hierbij in veel gevallen beroepen op mboniveau). Minder dan drie op de tien afgestudeerden die in 2011 in deze beroepsgroep actief was, is dit in 2015 nog steeds.

- Er is een toename van bijna 10 procentpunten tussen 2011 en 2015 in het aandeel afgestudeerden dat aan andere medewerkers leiding geeft.

- Het aandeel afgestudeerden met een vaste aanstelling is fors toegenomen tussen 2011 en 2015 (van 62\% naar 86\%). Onder degenen die in 2011 nog géén zicht hadden op een vaste baan, heeft ruim 75 procent deze in 2015 inmiddels toch verkregen.

- De lonen van afgestudeerden zijn tussen 2011 en 2015 gemiddeld met 4\% per jaar gestegen. De lonen zijn (zowel absoluut als relatief) het sterkst vooruitgegaan in de hbo-sectoren Landbouw, Techniek en Economie.

$1 \quad$ Een belangrijke voetnoot hierbij betreft dat enkel personen die op beide momenten in de data vertegenwoordigd zijn, in de analyses zijn opgenomen. Hierdoor komen in absolute zin de cijfers niet per se overeen met populatiegegevens. 
- Het aandeel afgestudeerden dat een baan heeft die zowel qua niveau als richting aansluit op de hbo-opleiding is slechts licht toegenomen tussen 2011 en 2015 (+3\%).

- Op het gebied van competentieontwikkeling, hebben in 2015 beduidend minder afgestudeerden tekorten en overschotten aan 'vakkennis' in vergelijking tot 2011. Op dit gebied is dus sprake van een sterk verbeterde match tussen de persoonlijke competenties van de afgestudeerde en vereiste competenties voor de baan.

- Bij andere competenties ('logisch redeneren', 'werken conform budget, planning, richtlijnen' en 'ideeën en oplossingen bedenken') is er gemiddeld genomen een afname te zien in het aandeel tekorten, maar niet in het aandeel overschotten. Er is hierbij dus slechts deels sprake van een verbeterde match tussen eigen en vereiste competenties.

- Het aandeel respondenten dat (zeer) tevreden was met de baan in zijn geheel, daalde met 4 procentpunten tussen 2011 en 2015. Deze daling is het sterkst in de sectoren Landbouw (-15\%) en Gezondheidszorg (-13\%). Afgestudeerden van de sector Economie zijn daarentegen juist iets tevredener in 2015 dan in 2011 (+7\%).

- Het percentage afgestudeerden dat (zeer) tevreden is over de hbo-opleiding is tussen 2011 en 2015 licht toegenomen (+3\%). Vooral afgestudeerden in de hbosectoren Landbouw (+9\%) en Gezondheidszorg (+7\%) zijn in de loop van de jaren positiever geworden. Bij de overige sectoren is weinig veranderd.

- Hoewel men in het algemeen tevredener is geworden over de gevolgde opleiding, is op het specifieke punt van de voorbereiding op de (verdere) loopbaan juist sprake van een lichte daling in de mate van tevredenheid. Deze daling blijkt het sterkst in de hbo-sector Onderwijs (-15\%).

- In 2015 zouden minder afgestudeerden dan in 2011 wederom voor hun hbo-opleiding kiezen als ze weer voor de keuze zouden staan (-6\%). De belangrijkste redenen waarom ze hier niet meer voor zouden kiezen, hebben betrekking op de arbeidsmarktperspectieven van de opleiding, de uitdaging die de opleiding bood, en de aansluiting van het curriculum bij de huidige beroepspraktijk. 


\section{1 \\ INLEIDING}

De HBO-Monitor is een jaarlijks enquêteonderzoek onder afgestudeerde hbo'ers dat in kaart brengt hoe de transitie van het hoger beroepsonderwijs (hbo) naar de arbeidsmarkt verloopt. Het onderzoek levert een schat aan informatie op, bijvoorbeeld over hoe afgestudeerden over hun opleiding denken, wat hun baankansen zijn, in welke functies zij terechtkomen en over welke kennis en vaardigheden zij beschikken. Specifiek voor de kunstensector is de Kunsten Monitor ontwikkeld.

De reguliere meting die een jaar na afstuderen $(T+1)$ plaatsvindt, geeft een goed beeld van hoe de initiële overgang naar de arbeidsmarkt is verlopen. Een hbo-opleiding is echter meer dan alleen training voor de eerste baan, en vooral bedoeld als een voorbereiding op een beroepscarrière. Het is daarom tevens belangrijk om te weten hoe de carrière van hbo-afgestudeerden zich verder ontwikkelt. In 2015 is om deze reden naast de reguliere $T+1$ meting ook een meting vijf jaar na afstuderen $(T+5)$ uitgevoerd. Bij deze $\mathrm{T}+5$ meting zijn afgestudeerden die in 2011 aan de reguliere HBO-Monitor deelnamen (en dus in studiejaar 2009-2010 afgestudeerd waren), in 2015 nogmaals benaderd. Vijf jaar na afstuderen, beschikken respondenten inmiddels over heel wat nieuwe beroepservaringen, waardoor niet alleen hun concrete arbeidsmarktpositie maar ook hun initiële opinies over hun opleiding, competenties en carrièreperspectieven kunnen zijn veranderd.

Op basis van het $T+5$ onderzoek zullen een aantal deelrapporten worden uitgebracht waarin verschillende aspecten van de loopbaanontwikkeling van hbo'ers zullen worden uitgelicht. Voorliggend rapport is het eerste in deze reeks. Omdat het hier de eerste uitkomsten betreft, is het rapport vooral beschrijvend van aard. In dit rapport presenteren we de resultaten van de analyses op basis van de gekoppelde data van respondenten die zowel aan de $\mathrm{T}+1$ als $\mathrm{T}+5$ meting van de HBO-Monitor hebben deelgenomen, en onderzoeken we hoe de arbeidsmarktcarrière van deze hbo'ers zich gedurende de eerste vijf jaar na afstuderen ontwikkeld heeft. Aan de hand van de gekoppelde data kunnen we de volgende vragen beantwoorden:

1. Hoe ontwikkelt de loopbaan van hbo-afgestudeerden (o.a. op het gebied van salaris, aanstelling en niveau) zich gedurende de eerste 5 jaar na afstuderen?

2. In hoeverre verbetert de aansluiting tussen eigen en vereiste competenties zich gedurende de eerste 5 jaar na afstuderen? 
3. Hoe kijken afgestudeerden 5 jaar na afstuderen terug op hun hbo-opleiding als ze reeds een tijd gesetteld zijn op de arbeidsmarkt? Heeft hun langere werkervaring een grote invloed op hun waardering van hun opleiding?

Dit rapport is als volgt opgebouwd. Allereerst geven we een overzicht van de relevante arbeidsmarkttheorieën waarmee we de onderzoeksresultaten nader kunnen duiden. Vervolgens staan we stil bij de data en onderzoeksmethode die voor de huidige analyses zijn gebruikt. Daarna bespreken we de onderzoeksresultaten met betrekking tot arbeidsmarktuitkomsten en aansluitend de resultaten over studietevredenheid. Ten slotte sluiten we af met een discussie waarin alle bevindingen nog eens op een rij worden gezet en in perspectief worden geplaatst. 


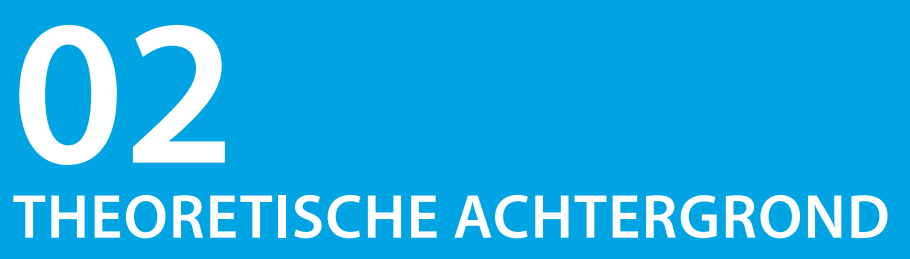

Mensen kunnen verschillende motieven hebben voor het volgen van een hbo-opleiding, maar voor de meesten is het een investering in hun toekomst, die zich over vele jaren moet terugbetalen op de arbeidsmarkt. Dit is een van de basisgedachten van de menselijk kapitaaltheorie, die aan het begin van de jaren zestig door economen als Becker (1964) en Schultz (1963) is ontwikkeld: mensen blijven investeren in hun productieve capaciteiten zolang als de waarde van de verwachte toekomstige opbrengsten hoger is dan de kosten. De opbrengsten worden vaak uitgedrukt in termen van geld, maar uit onderzoek blijkt dat niet-materiele opbrengsten, zoals professionele en persoonlijke ontwikkeling, uitdaging en de mogelijkheid om vaardigheden te gebruiken, voor veel mensen net zo belangrijk of zelfs belangrijker zijn (Allen e.a. 2007). De kosten bestaan onder andere uit collegegeld, levensonderhoud tijdens de opleiding, opgeofferde inkomsten uit werk dat men had kunnen verrichten in plaats van te studeren, en de psychische inspanning van de studie. Een vergelijkbare kosten-baten afweging vindt plaats meteen na het verlaten van de opleiding. De meeste afgestudeerden kiezen ervoor om na afronding van de hbo-opleiding meteen de arbeidsmarkt op te gaan, maar er zijn andere opties, zoals doorstuderen. De keuze tussen meteen te starten op de arbeidsmarkt of nog verder gaan studeren zou bij de afgestudeerden die zijn benaderd voor het huidige onderzoek mogelijk kunnen zijn beïnvloed door het feit dat deze afgestudeerden de hbo-opleiding verlieten tijdens de recente financiële crisis. Door de afgenomen werkgelegenheid gedurende die periode zouden de verwachte arbeidsmarktopbrengsten van een hbo-opleiding op de korte termijn een stuk lager kunnen zijn, en zou als gevolg de keuze om door te studeren juist een stuk aantrekkelijker kunnen zijn.

Voor afgestudeerden die na het verlaten van de opleiding gedurende lange tijd vergeefs naar (passend) werk hebben gezocht, zou op een gegeven moment ook een zogenaamd discouraged worker effect (in het Nederlands: ontmoedigd werkzoeker effect; zie bijvoorbeeld Akyeampong, 1992) kunnen zijn opgetreden. Van dit effect is sprake wanneer men na lange tijd actief zoeken, stopt met het zoeken naar werk, en zich (voorlopig) richt op andere bezigheden zoals studie, reizen of vrijwilligerswerk. Een andere keuze waar sommige afgestudeerden voor komen te staan gedurende de eerste jaren na het afstuderen, is de keuze tussen het snel aan de slag gaan op de arbeidsmarkt en het wachten op een beter passende baan. Er is veel literatuur die erop wijst dat een goede aansluiting tussen de kwalificaties van een werknemer en de inhoud van de baan een sterke invloed heeft op de geleverde werkprestaties, en daarom ook op de beloning 
(Sattinger, 2012), evenals op baantevredenheid (Allen \& Van der Velden, 2001). Dit zou aanleiding kunnen zijn voor afgestudeerden om niet meteen genoegen te nemen met de eerste de beste baan, maar verder rond te blijven kijken naar een baan die beter bij de gevolgde hbo-opleiding past. De vraag of wachten wel of niet verstandig is, is moeilijk op eenduidige wijze te beantwoorden. Op zeer korte termijn heeft wachten zeker zin: op de arbeidsmarkt is er altijd een zekere frictiewerkloosheid, als gevolg van het feit dat het tijd kost om vraag en aanbod bij elkaar te brengen (Mortensen e.a., 1994). Zelfs de door werkgevers meest gewilde afgestudeerden zullen daarom enige tijd nodig hebben om een geschikte baan te vinden, en hoeven dus niet meteen een baan te aanvaarden waarvoor bijvoorbeeld geen of weinig scholing is vereist. Na enkele maanden van zonder succes zoeken zullen sommige afgestudeerden echter overwegen om tijdelijk een minder passende baan te accepteren, om zo inkomsten te verwerven en ervoor te zorgen dat hun contact met de arbeidsmarkt niet verloren gaat. Volgens de wachtkamerhypothese (Asselberghs e.a., 1998) biedt dit een verklaring voor het relatief hoge percentage recente schoolverlaters dat onder het eigen opleidingsniveau of buiten de eigen opleidingsrichting werkt. Deze hypothese voorspelt dat dit vooral een tijdelijke situatie is, en dat men op termijn door zal stromen naar banen die beter bij de opleiding passen. Uit eerder onderzoek blijkt dat dit inderdaad meestal het geval is, maar dat een klein percentage blijft steken op het initiële lagere niveau (Allen e.a. 2007). Dat kleine percentage zou echter niet zonder meer beter af zijn geweest als ze hadden 'gewacht' op passend werk. Langdurige werkloosheid aan het begin van de loopbaan kan immers in sommige gevallen ook lange negatieve 'naweeën' hebben (zie bijvoorbeeld Nilsen en Reiso, 2011).

$\mathrm{Na}$ het verkrijgen van de eerste baan kan men grof gezegd op twee verschillende manieren vooruit komen. Ten eerste kan men promotie maken binnen dezelfde organisatie. Sicherman en Galor (1990) hebben aangetoond dat een fors deel van het rendement op onderwijsinvesteringen in de toegang tot banen binnen bedrijven met veel ontwikkelperspectief zit. Het gaat hier voornamelijk om banen waarbij al bij aanvang een min of meer expliciet ontwikkeltraject wordt uitgestippeld. De tweede route van carrièreontwikkeling betreft externe baanmobiliteit: het zoeken vanuit een bepaalde baan naar een beter alternatief bij een andere werkgever (Lam e.a., 2012). Beide routes kunnen soms door dezelfde persoon worden bewandeld in verschillende fasen van de loopbaan. Zo kan iemand kort na afstuderen een baan aanvaarden met weinig carrièreperspectieven, om van daaruit een plek te zoeken bij een bedrijf dat wel interne groeimogelijkheden biedt. In de praktijk is door de werknemer geïnitieerde baanmobiliteit vaak moeilijk te onderscheiden van gedwongen mobiliteit als gevolg van een lage mate van werkzekerheid (Lazear, 1990). Wat dat betreft heeft wetgeving op het gebied van werkzekerheid vaak een tweeledig effect: enerzijds biedt dit een bescherming aan werknemers die al aangenomen zijn door een bedrijf, omdat ze niet zo maar kunnen worden ontslagen. Zulke bescherming wordt meestal positief gewaardeerd door zittend personeel, en blijkt bovendien bevorderend te werken op de bereidheid van werknemers te investeren in bedrijfsspecifieke vaardigheden (Estévez-Abe e.a. 2001). Anderzijds kan dit het moeilijker maken om aangenomen te worden door bedrijven, en kan het een druk- 
kend effect hebben op de werkgelegenheid (Heckman en Pages, 2000). Nederland kent een relatief hoge mate van arbeidsmarktbescherming (OECD, 2009). Hierdoor ligt het voor de hand dat men bij voorkeur de route van de interne mobiliteit kiest, en voor zover mogelijk de meer riskante route van de externe mobiliteit vermijdt. Wel is mogelijk dat door de recente recessie veel mensen noodgedwongen deze laatste route hebben moeten bewandelen.

Ten slotte is er veel onderzoek waaruit blijkt dat de tevredenheid met gevolgde opleiding mede wordt beïnvloed door verschillende aspecten van arbeidsmarktsucces, zoals inkomen, aansluiting tussen de opleiding en de baan en carrièreperspectieven (Allen e.a. 2007; McLoy en Lui, 2010). Vooral de mate waarin men werk heeft gevonden waarin men zijn/haar eigen interesses en capaciteiten tot uitdrukking kan laten komen, en kansen ziet om zich in zijn/haar werk te blijven ontwikkelen, blijkt van groot belang te zijn voor opleidingstevredenheid (Støren, en Arnesen, 2011). Afgestudeerden blijken over het algemeen goed in staat te zijn om in hun oordeel over de opleiding te (kunnen) differentiëren naar verschillende aspecten zoals de kwaliteit van het onderwijs, de voorbereiding op de arbeidsmarkt, en de studie- en beroepsvoorlichting. Ze hebben over het algemeen dus bepaald geen eenzijdig beeld van de opleiding. Wel blijken initiële oordelen over opleidingsaspecten later te worden bijgesteld op basis van de opgedane ervaringen op de arbeidsmarkt (Allen e.a. 2007). 



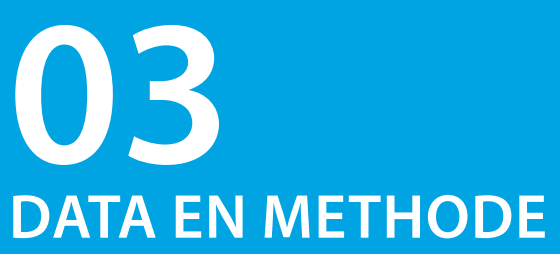

\subsection{Methode}

De onderzoeksgegevens voor dit rapport zijn verzameld aan de hand van twee metingen. Enerzijds via de oorspronkelijke meting uit de HBO-Monitor 2011 (voor afgestudeerden uit studiejaar 2009/2010), en anderzijds via de 'herhalingsmeting'2 ${ }^{2}$ uit 2015 . In beide metingen is (onder meer) de positie van afgestudeerden op de arbeidsmarkt bevraagd, respectievelijk één en vijf jaar na afstuderen.

De T+5-meting is uitgevoerd aan de hand van online vragenlijsten onder afgestudeerden. De afgestudeerden zijn per e-mail benaderd voor deelname aan het onderzoek, waarin zij een link en inlogcode naar de vragenlijst aantroffen. De e-mailadressen van de alumni zijn aangeleverd door hogescholen die participeerden in de T+5-meting: door deel te nemen aan het onderzoek hebben zij zich gecommitteerd aan de gegevenslevering. In totaal heeft $80 \%$ van de hogescholen die eerder hadden deelgenomen aan de oorspronkelijke HBO-Monitor meting in 2011, tevens deelgenomen aan de T+5 meting in 2015. Van de hogescholen die niet aan de herhalingsmeting wensten mee te doen, zijn enkel de respondenten benaderd die in de oorspronkelijke meting hadden aangegeven opnieuw aan onderzoek te willen meewerken. Het veldwerk is verricht in de periode 1 september tot 31 december. Om de respons te verhogen is een waardebon verloot ( $\mathrm{ad} € 450$ ) onder de deelnemers en zijn in november en december 2015 meerdere herinneringen verzonden aan degenen die de vragenlijst nog niet hadden ingevuld. De respons op het moment van sluiting van de vragenlijst betrof $11,2 \%$.

\subsection{Bestandskoppelingen}

Om de individuele ontwikkeling tussen 2011 en 2015 (respectievelijk één jaar en vijf jaar na afstuderen, oftewel $\mathrm{T}+1$ en $\mathrm{T}+5$ ) in kaart te brengen, is het noodzakelijk om de twee metingen op persoonsniveau te matchen. Het koppelen van deze onderzoeksbestanden is alleen mogelijk gebleken aan de hand van e-mailadressen. Door deze beperking heeft voor ongeveer de helft van de respondenten uit de $\mathrm{T}+5$-meting een succesvolle koppe-

2 De term 'herhaling' moet hier ruim geïnterpreteerd worden. Dezelfde groep afgestudeerden zijn grotendeels de oorspronkelijke vragen gesteld, maar daarnaast zijn er aanvullende, nieuwe vragen opgenomen. 
ling met de T+1-meting plaats kunnen vinden ${ }^{3}$. Respondenten waarvan de onderzoeksgegevens uit 2011 en 2015 gematcht konden worden, noemen we derhalve de 'koppelbare responsgroep', respondenten waarvan geen gegevensmatch mogelijk is geweest noemen we de 'niet-koppelbare responsgroep'. Hoewel de onderzoeksgegevens van de 'niet-koppelbare responsgroep' wel zinvol en bruikbaar zijn voor analyses op het T+5-bestand op zich, zijn ze niet bruikbaar om individuele ontwikkelingen (tussen 2011 en 2015) te monitoren. In voorliggend rapport worden om deze reden alleen analyses uitgevoerd op de 'koppelbare responsgroep'. De omvang van deze responsgroep betreft 2.654 personen. Dit betreft overigens het 'maximale' aantal respondenten: in de rapportage zal het aantal respondenten tussen de figuren en tabellen fluctueren. Fluctuatie is mogelijk omdat respondenten 'missende waarden' kunnen hebben op vragen, bijvoorbeeld wanneer zij vragen hebben overgeslagen. Aangezien respondenten zowel ontbrekende antwoorden kunnen hebben in de vragenlijst uit 2011 als uit 2015 kan het aantal waarnemingen per onderzoeksvariabele verschillen.

\subsection{Responsgroep en representativiteit}

In deze paragraaf kijken we naar de samenstelling en de representativiteit van de'koppelbare responsgroep' (vanaf hier: responsgroep). De representativiteit van de responsgroep wordt geanalyseerd door de samenstelling van deze T+5-groep te verhouden tot de samenstelling van de totale afgestudeerdenpopulatie uit studiejaar 2009/2010. Voor de samenstelling van de volledige afgestudeerdenpopulatie wordt geput uit gegevens uit de HBO-Monitor 2011 (T+1-meting). Deze gewogen groep uit 2011 is representatief naar een viertal factoren, te weten: de opleiding (croho), de regio, het type opleiding (voltijd/deeltijd/duaal) en het geslacht van de respondenten en kan derhalve als goede benadering van de 'ware', totale hbo-afstudeerpopulatie uit 2011 worden beschouwd.

In Tabel 3.1 is de samenstelling van de gehele afgestudeerdenpopulatie (studiejaar 2009/2010) afgezet tegen de samenstelling van de T+5-responsgroep. Hierbij is gekeken naar de onderwijssector, het type inschrijving, het geslacht, de etniciteit, de leeftijd (anno 2011) en de vooropleiding van de afgestudeerden. De responsgroep uit de T+5-meting blijkt - met uitzondering van geslacht - op alle kenmerken significant af te wijken van de totale populatie, en is statistisch gezien dus niet (volledig) representatief. De omvang van de afwijkingen is echter slechts beperkt: we zien alleen een relatief sterke afwijking bij het aantal respondenten uit de sector Economie en onder voltijdstudenten (zie onderstreepte percentages in tabel). Deze twee groepen blijken ondervertegenwoordigd in de T+5-respons. De algemene verhoudingen, zoals deze in de populatie bestaan (o.a. het relatief grote aandeel Economie-afgestudeerden), zijn echter ook in de responsgroep duidelijk herkenbaar. Om deze redenen is besloten om niet te wegen naar deze kenmerken. De T+5-responsgroep bestaat zoals gezegd uit ruim 2.654 respondenten. Drie op de tien (30\%) van hen heeft een opleiding gevolgd in de

3 De andere helft is niet koppelbaar gebleken, omdat het e-mailadres zoals bekend in 2011 niet overeenkwam met het e-mailadres zoals bekend in 2015 . 
richting Economie. Andere grote richtingen zijn onder meer Techniek (17\%) en Gedrag \& Maatschappij (15\%). De kleinste opleidingssector betreft Landbouw (3\%). Kijken we naar het inschrijvingstype van de respondenten, dan blijkt dat ruim driekwart voltijdstudent was (77\%), twee-tiende deeltijder (19\%) en slechts een klein deel duale student (4\%). De verdeling naar geslacht betreft 56 procent vrouw en 44 procent man. Bijna negen op de tien respondenten (89\%) zijn van autochtone afkomst, 7 procent is van westersallochtone afkomst en 5 procent kent een niet-westers allochtone herkomst. Kijken we naar de leeftijden van de respondenten ten tijde van de 2011-meting, dan was ruim viertiende (42\%) 24 jaar of jonger, was ruim een derde (36\%) 25 tot en met 29 jaar en was de overige 22 procent 30 jaar of ouder. Tot slot blijkt ruim vier op de tien respondenten (43\%) voorafgaand aan de hbo-opleiding op de havo te zitten, kwam bijna drie tiende (27\%) van het mbo, zat 16 procent op het vwo en was het resterende deel afkomstig van een hbo-opleiding of een ander type vooropleiding.

\subsection{Representativiteit nader beschouwd}

Hoewel uit Tabel 3.1 geen opvallende vertekeningen naar achtergrondkenmerken naar voren komen, blijkt uit nadere analyse dat de T+5-responsgroep wel als een heel specifieke groep beschouwd moet worden. De responsgroep is namelijk een relatief 'succesvolle' groep op de arbeidsmarkt. Zo was de werkloosheid in 2011 in de totale populatie afgestudeerden uit 2009/2010 (op basis van de HBO-Monitor 2011) ruim 5 procent, terwijl deze onder de $\mathrm{T}+5$-responsgroep minder dan 4 procent betrof. Bij het lezen van deze rapportage is het derhalve van belang om rekening te houden met dit specifieke karakter van de onderzoekspopulatie.

TABEL 3.1 Samenstelling van totale afgestudeerdenpopulatie (o.b.v. HBO-Monitor 2011) en koppelbare responsgroep $\mathrm{T}+5$-meting.

\begin{tabular}{|c|c|c|c|c|}
\hline & \multicolumn{2}{|c|}{$\begin{array}{r}\text { HBO-MONITOR } 2011 \\
\text { TOTAAL }\end{array}$} & \multicolumn{2}{|c|}{$\begin{array}{r}\text { HBOT+5 KOPPELBARE } \\
\text { RESPONSGROEP }\end{array}$} \\
\hline & Aantal & Percentage & Aantal & Percentage \\
\hline \multicolumn{5}{|c|}{ HBO ONDERWIJSSECTOR (sign.) } \\
\hline Landbouw & 1.426 & $2 \%$ & 80 & $3 \%$ \\
\hline Onderwijs & 9.096 & $16 \%$ & 348 & $13 \%$ \\
\hline Techniek & 9.137 & $16 \%$ & 464 & $17 \%$ \\
\hline Economie & 20.977 & $36 \%$ & 789 & $30 \%$ \\
\hline Gezondheidszorg & 6.104 & $10 \%$ & 359 & $14 \%$ \\
\hline Gedrag \& Maatschappij & 7.935 & $14 \%$ & 403 & $15 \%$ \\
\hline Taal \& Cultuur & 3.872 & $7 \%$ & 211 & $8 \%$ \\
\hline \multicolumn{5}{|c|}{ TYPE INSCHRIJVING (sign.) } \\
\hline voltijd & 47.402 & $81 \%$ & 2.040 & $77 \%$ \\
\hline deeltijd & 9.222 & $16 \%$ & 503 & $19 \%$ \\
\hline duaal & 1.924 & $3 \%$ & 111 & $4 \%$ \\
\hline
\end{tabular}




\begin{tabular}{|c|c|c|c|c|}
\hline & \multicolumn{2}{|c|}{$\begin{array}{r}\text { HBO-MONITOR } 2011 \\
\text { TOTAAL }\end{array}$} & \multicolumn{2}{|c|}{$\begin{array}{r}\text { HBO T+5 KOPPELBARE } \\
\text { RESPONSGROEP }\end{array}$} \\
\hline \multicolumn{5}{|l|}{ GESLACHT (niet sign.) } \\
\hline man & 25.354 & $43 \%$ & 1.152 & $44 \%$ \\
\hline vrouw & 33.154 & $57 \%$ & 1.446 & $56 \%$ \\
\hline \multicolumn{5}{|l|}{ ETNICITEIT (sign.) } \\
\hline westerse allochtoon & 4.301 & $8 \%$ & 141 & $7 \%$ \\
\hline niet-westerse allochtoon & 3.934 & $7 \%$ & 93 & $5 \%$ \\
\hline autochtoon & 45.137 & $85 \%$ & 1.823 & $89 \%$ \\
\hline \multicolumn{5}{|l|}{ LEEFTIJD IN 2011 (sign.) } \\
\hline t/m 24 jaar & 25.489 & $44 \%$ & 1.134 & $43 \%$ \\
\hline 25-29 jaar & 22.516 & $39 \%$ & 942 & $36 \%$ \\
\hline 30-39 jaar & 5.937 & $10 \%$ & 298 & $11 \%$ \\
\hline 40 of ouder & 4.507 & $8 \%$ & 277 & $10 \%$ \\
\hline \multicolumn{5}{|l|}{ VOOROPLEIDING (sign.) } \\
\hline havo & 25.712 & $44 \%$ & 1.113 & $43 \%$ \\
\hline vwo & 8.937 & $15 \%$ & 417 & $16 \%$ \\
\hline bol/bbl/inservice & 15.947 & $27 \%$ & 688 & $27 \%$ \\
\hline hbo & 5.718 & $10 \%$ & 212 & $8 \%$ \\
\hline wo & 84 & $0 \%$ & 0 & $0 \%$ \\
\hline Andere vooropleiding & 1.773 & $3 \%$ & 134 & $5 \%$ \\
\hline
\end{tabular}




\section{4 \\ VERANDERINGEN IN ARBEIDSMARKT- UITKOMSTEN TUSSEN 2011 EN 2015}

\subsection{Welke maatschappelijke posities bekleden hbo-afgestudeerden 5 jaar na afstuderen?}

Voordat we nagaan welke details van de arbeidsmarktsituatie van afgestudeerden 5 jaar na afstuderen zijn veranderd, werpen we eerst een blik op de brede maatschappelijke positie die afgestudeerden één en vijf jaar na afstudeerden innemen. Het gaat hierbij om hoe afgestudeerden zelf hun eigen situatie omschrijven, niet om de formele arbeidsmarktstatus. We onderscheiden hierbij drie categorieën, namelijk werk, studie en anders. Figuur 4.1 toont de verdeling van afgestudeerden van afstudeerjaar 2010 over deze drie categorieën in 2011 en 2015 (respectievelijk één en vijf jaar na afstuderen).

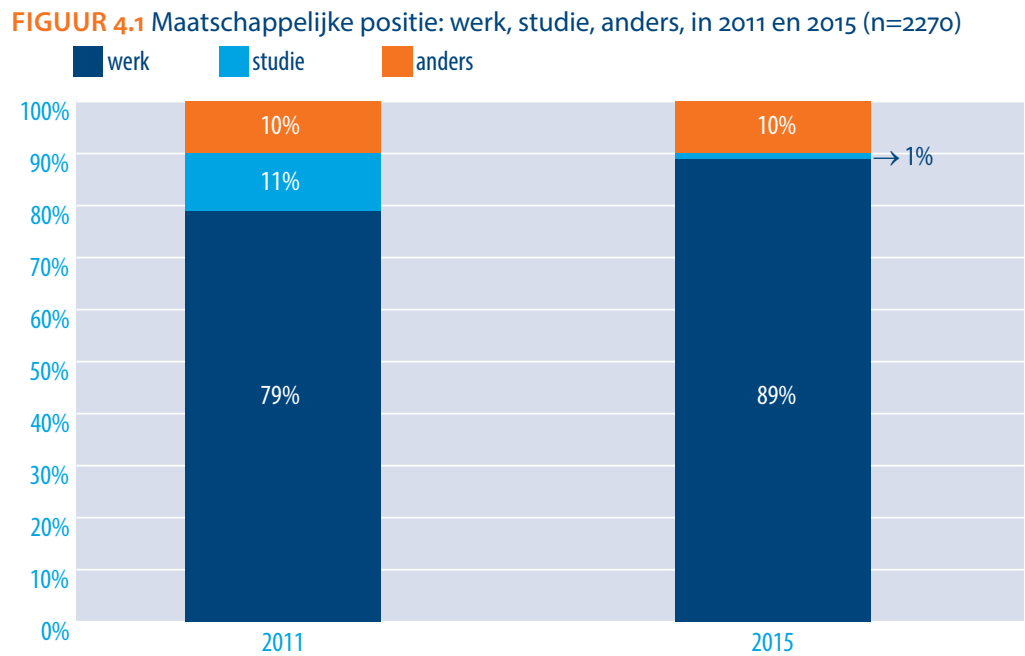

Zowel in 2011 als 2015 benoemen de meeste afgestudeerden 'werk' als de bezigheid die hun maatschappelijke positie het best beschrijft. Het grote verschil tussen de twee jaren ligt in het aanzienlijk hogere percentage afgestudeerden dat in 2011 studie als hoofdbezigheid heeft. Dit ligt natuurlijk voor de hand: uit de reguliere HBO-Monitor is al bekend dat een substantieel deel van de afgestudeerden naar vervolgonderwijs doorstroomt. 
Uit Figuur 4.1 blijkt dat slechts weinig afgestudeerden (1\%) vier jaar later studie nog als hoofdbezigheid hebben. De'anders'-groep is in beiden jaren even groot.

Een nadere bestudering van de 'anders' categorie laat zien dat deze voor iets meer dan de helft bestaat uit mensen die weliswaar werkzaam zijn, maar dit combineren met studie of een andere bezigheid. Slechts een derde van de 'anders-categorie' bestaat uit werklozen. Een klein deel van de 'anders' categorie (zo'n 10\%) geeft in 2011 aan zorg te dragen voor kinderen of andere familieleden. In 2015 is dit aandeel uitgegroeid tot ongeveer een derde van de 'anders' categorie. ${ }^{5}$

Figuur 4.2 laat zien in hoeverre de maatschappelijke positie in 2011 nog doorspeelt in 2015. Hieruit blijkt dat van alle drie categorieën in 2011, een grote meerderheid in hun situatie in 2015 als 'werk' omschrijft. 85\% van degenen die in 2011 'studie als belangrijkste bezigheid aanduidden, en $77 \%$ van degenen die in 2011 in de anders-categorie viel, geeft in 2015 aan met name werkend te zijn. Dit percentage is wel het hoogste onder de mensen die in 2011 hun situatie ook zo omschreven.

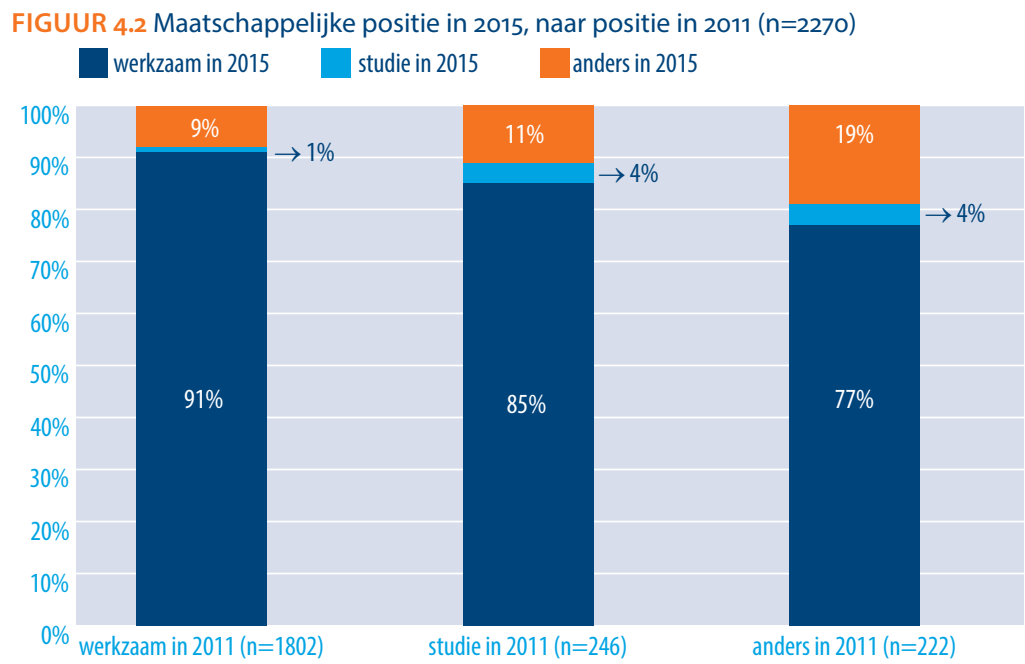

\subsection{Veranderingen in werkloosheid gedurende de eerste 5 jaar na afstuderen}

In Figuur 4.3 beschrijven we de formele arbeidsmarktsituatie in termen van het percentage afgestudeerden dat in 2011 en 2015 werkloos ${ }^{6}$ was. Te zien is dat het werkloosheids-

5 Deze verdelingen verschillen weinig op beide meetmomenten tussen afgestudeerden van voltijd, deeltijd en duale opleidingen.

6 Tot de werkzame beroepsbevolking behoort iedereen die 1 of meer uren per week betaald werk verricht. Mensen die geen betaald werk hebben maar hier wel naar op zoek zijn vormen de werkloze beroepsbevolking. 
percentage nauwelijks veranderd is tussen 2011 en 2015. Dit is niet zo vreemd, aangezien een werkloosheidspercentage van rond de $3 \%$ als 'frictiewerkloosheid'7 kan worden beschouwd.

Wel toont de figuur verschillende beelden voor afgestudeerde voltijdstudenten enerzijds en deeltijd/duale studenten anderzijds. Waar de werkloosheid licht daalt tussen 2011 en 2015 voor afgestudeerden van voltijdopleidingen, stijgt deze voor afgestudeerden van deeltijd en duale opleidingen in dezelfde periode juist. Op zich is dit niet zo verwonderlijk, aangezien deeltijd/duale studenten hun opleiding (meestal) combineren met een baan. Waar voor hen de uitgangspositie tijdens de opleiding 'werk' is, is de uitgangpositie voor voltijdstudenten (meestal) juist 'geen werk'. In die zin kunnen voltijdstudenten er in de jaren na afstuderen doorgaans alleen maar op 'vooruit' gaan, terwijl deeltijd/ duale studenten juist iets 'te verliezen' hebben. Naast verschillen in werkloosheid tussen voltijdstudenten en deeltijd/duale studenten, zijn verder wat verschillen in de werkloosheidsontwikkeling op het niveau van opleidingssectoren (niet weergegeven in figuur). Deze verschillen vertonen echter geen duidelijk patroon en zijn waarschijnlijk slechts toevallige fluctuaties gebaseerd op kleine aantallen.

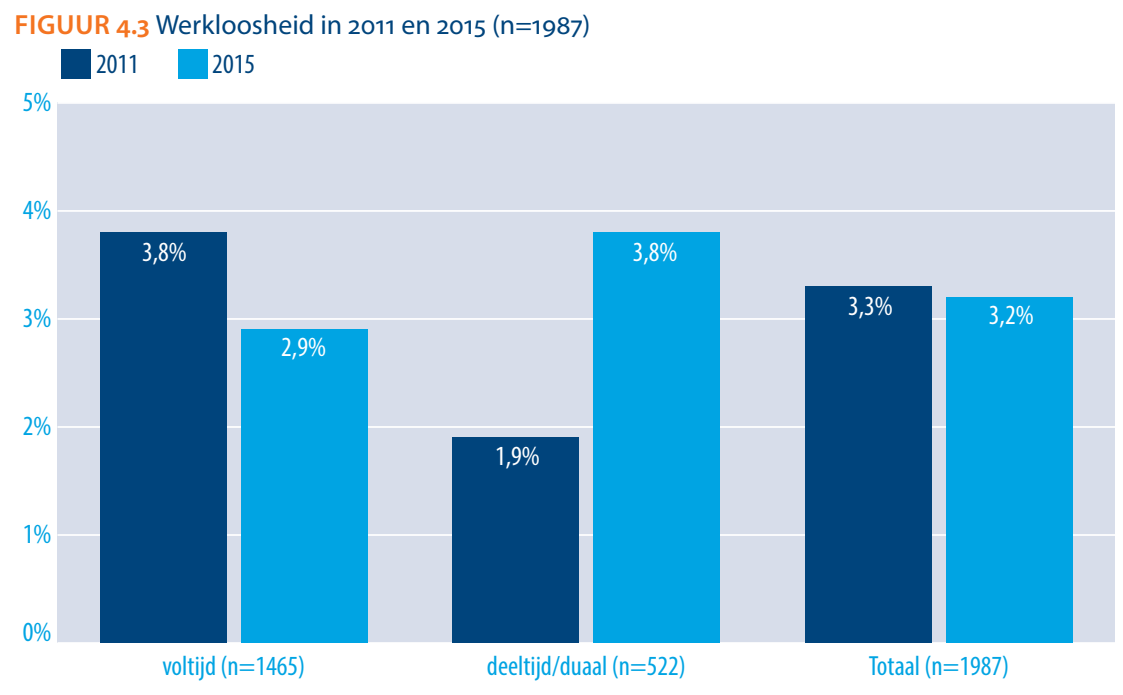

Noot. Alleen personen die zowel in 2011 als 2015 tot de beroepsbevolking behoren.

Afgestudeerden die in 2011 werkloos waren hebben echter een veel grotere kans om dat in 2015 nog steeds te zijn, dan afgestudeerden die in 2011 tot de werkzame beroepsbevolking $^{5}$ behoorden (zie Figuur 4.4). Deze bevinding is in lijn met eerder onderzoek, waaruit blijkt dat werkloosheid op jongere leeftijd de kans op werkloosheid op latere leeftijd

7 Frictiewerkloosheid is dat deel van de werkloosheid dat veroorzaakt wordt door fricties op de arbeidsmarkt. Fricties (wrijvingen) tussen vraag en aanbod zijn onvermijdelijk bij een markt die zo complex is als de arbeidsmarkt. 
vergroot. Zelfs wanneer hierbij rekening gehouden wordt met onder meer individuele vaardigheden en sociaaleconomische achtergrond van jongeren (o.a. Gregg, 2001). Een verklaring hiervoor ligt in het discouraged worker effect dat werklozen kunnen ondergaan. Hoewel werkloosheid in eerste instantie tot extra inzet en motivatie kan leiden, kunnen opeenvolgende teleurstellingen tot pessimisme leiden en leggen werklozen zich soms (tijdelijk) 'neer' bij hun situatie. We kunnen echter ook met een meer rooskleurige bril naar de resultaten kijken: de overgrote meerderheid van de werklozen uit 2011, is in 2015 werkzaam. Mogelijk kan werkloosheid, conform de menselijk kapitaaltheorie die ervan uitgaat dat mensen in zichzelf blijven investeren zolang de opbrengsten hoger zijn dan de kosten, inderdaad (initieel) juist activerend werken. Onderzoek van Mroz \& Savage (2006) laat bijvoorbeeld zien dat werklozen vaker deelnemen aan trainingen dan werkenden.

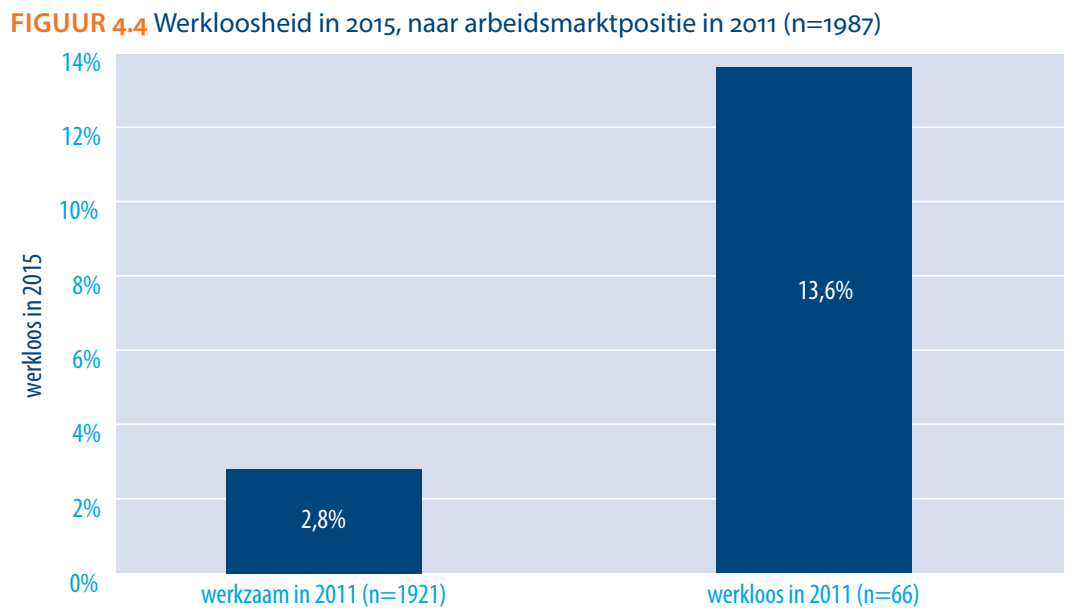

Noot. Alleen personen die zowel in 2011 als 2015 tot beroepsbevolking behoren.

\subsection{Veranderingen in aantal werkgevers gedurende de eerste 5 jaar na afstuderen}

Figuur 4.5 toont dat er grote verschillen zijn tussen afgestudeerden in de mate van verandering van baan in de eerste jaren sinds het verlaten van de opleiding. Ruim een derde van de afgestudeerden heeft slechts één werkgever gehad in de eerste vijf jaren sinds afstuderen, en een iets kleiner deel heeft in deze periode twee werkgevers gehad (en is dus één keer van werkgever veranderd). lets minder dan een vijfde deel van de afgestudeerden heeft drie werkgevers gehad. Bij de overige $16 \%$ is sprake van een relatief frequente verandering van baan. Hoewel het wisselen van baan noodgedwongen kan zijn (bijvoorbeeld einde van dienstverband), gaat het in Nederland in de overgrote meerderheid van de gevallen om een baanwisseling die door werknemer zelf geïnitieerd wordt. De belangrijkste reden hiervoor betreft de verwachting dat men een betere en/of meer passende baan vindt (Gesthuizen \& Dagevos, 2005). 
FIGUUR 4.5 Aantal werkgevers sinds afstuderen, inclusief eventuele huidige werkgever, in 2015 $(n=2485)$

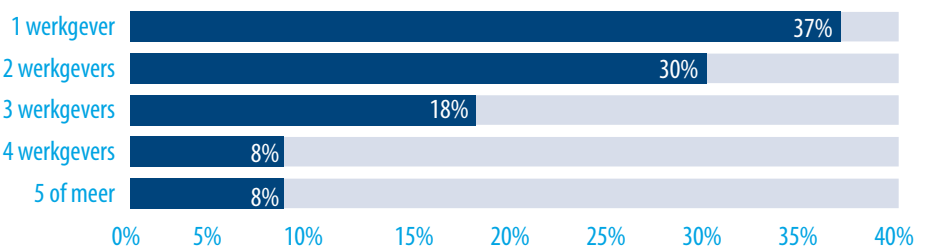

Noot. Exclusief personen die geen werkgevers hebben gehad (i.e. tot dusverre niet gewerkt), dit betreft $<1 \%$ van de responsgroep. Zelfstandigen worden zelf als ' 1 werkgever' gerekend.

Uit Figuur 4.6 blijkt verder dat er sterke verschillen tussen sectoren zijn in de frequentie van baanveranderingen. Terwijl slechts iets meer dan een kwart van de afgestudeerden in de sectoren Landbouw en Techniek drie of meer werkgevers hebben gehad, blijkt dit voor meer dan twee op de vijf afgestudeerden in de sectoren Onderwijs en Gedrag \& Maatschappij te gelden, en voor meer dan de helft van de afgestudeerden van de sector Taal \& Cultuur. De hoge mobiliteit van afgestudeerden uit deze sectoren heeft mogelijk te maken met de lager ingeschatte carrièremogelijkheden, de lagere lonen en de hogere werkdruk (waarover later meer). Vanuit de wetenschap dat baanwisselingen veelal vrijwillig plaats vinden in de zoektocht naar een betere baan, is het niet verrassend dat vooral bij deze groepen afgestudeerden er meer wisselingen plaats vinden.

FIGUUR 4.6 Percentage afgestudeerden met 3 of meer werkgevers, inclusief huidige werkgever, in 2015, naar sector, voltijd $(n=1898)$

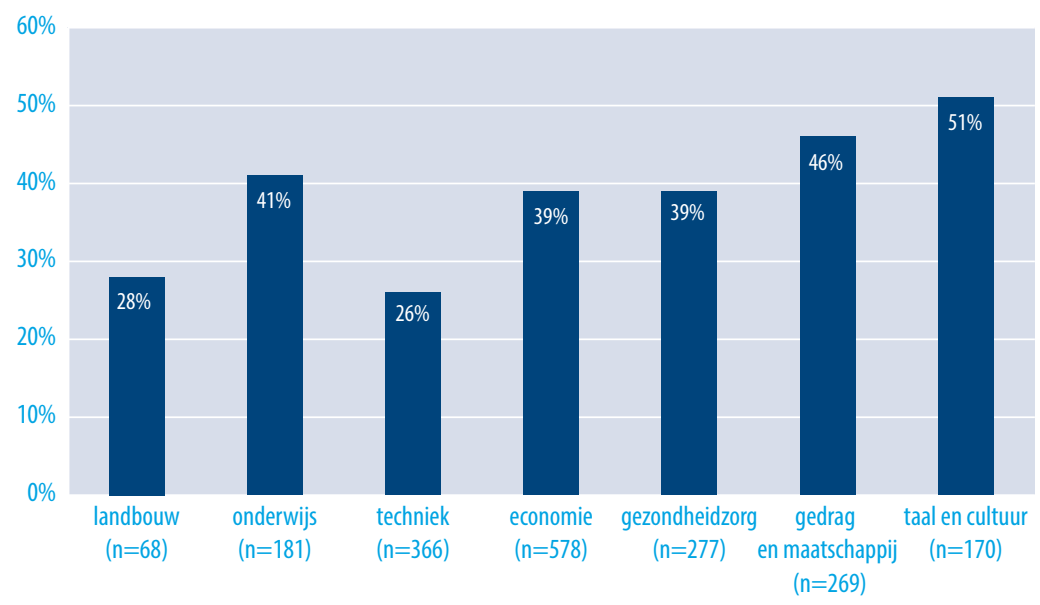

Noot. Exclusief personen die geen werkgevers hebben gehad (i.e. tot dusverre niet gewerkt), dit betreft $<1 \%$ van de responsgroep. 
Uit Figuur 4.7 kan worden opgemaakt dat de meeste veranderingen van werkgever al in het eerste jaar na afstuderen hebben plaatsgevonden. $62 \%$ van de afgestudeerden werkte immers in 2011 al in dezelfde functie bij dezelfde werkgever als nu, en nog ruim een vijfde werkte bij dezelfde werkgever maar in een andere functie. $36 \%$ is in deze periode van werkgever veranderd, en een paar procent had toen een andere werksituatie.

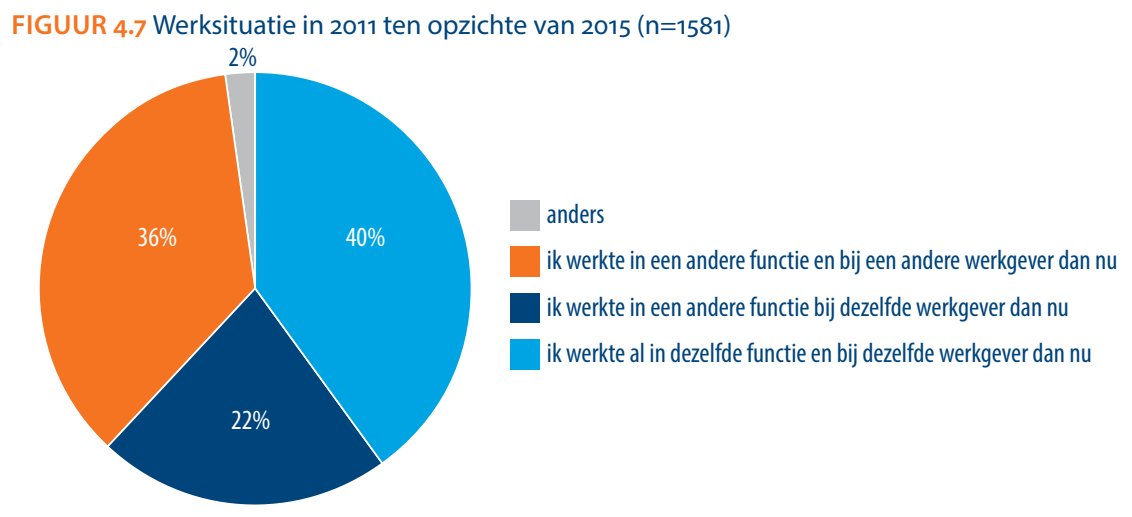

Noot. Alleen personen die in 2011 en 2015 tot werkzame beroepsbevolking behoorden.

\subsection{Veranderingen in bedrijfssectoren waarin afgestudeerden werkzaam zijn gedurende de eerste 5 jaar na afstuderen}

De bedrijfssectoren waar afgestudeerden in 2011 en 2015 werkzaam zijn, verschillen nauwelijks, zo volgt uit Figuur 4.8. Zowel in 2011 als in 2015 is de 'Gezondheids- en welzijnszorg' de grootste sector voor hbo'ers: bijna drie op de tien afgestudeerden zijn daar actief. Ook het Onderwijs is een grote werkgever in zowel 2011 als 2015, bijna twee op de tien werken in die sector. In alle sectoren waar hbo'ers werkzaam zijn, zien we tussen 2011 en 2015 slechts marginale verschillen van maximaal 1 procentpunt.

Hoewel voorgaande figuur lijkt te impliceren dat hbo'ers nauwelijks intersectoraal mobiel zijn (oftewel tussen 2011 en 2015 van sector wisselen), zien we in Figuur 4.9 dat daar wel degelijk sprake van is. Wel zijn er grote verschillen tussen de verschillende bedrijfssectoren. De intersectorale mobiliteit is relatief het grootst onder hbo'ers die in 2011 werkzaam waren in de 'Groot- en detailhandel; of reparatie van auto's'. Meer dan een derde van de afgestudeerden die in 2011 in die sector werkzaam waren, is nu elders werkzaam. Ook zien we dat er vrij veel uitstroom is bij de sectoren 'Advisering, onderzoek en overige specialistische zakelijke dienstverlening', 'Informatie en communicatie' en 'Financiële instellingen'. Ruim een kwart van de hbo'ers die in 2011 in betreffende sectoren werkten, is nu elders werkzaam. 
FIGUUR 4.8 Bedrijfssector waar men werkzaam in is, in 2011 en 2015, retrospectief $(n=1548)^{8}$

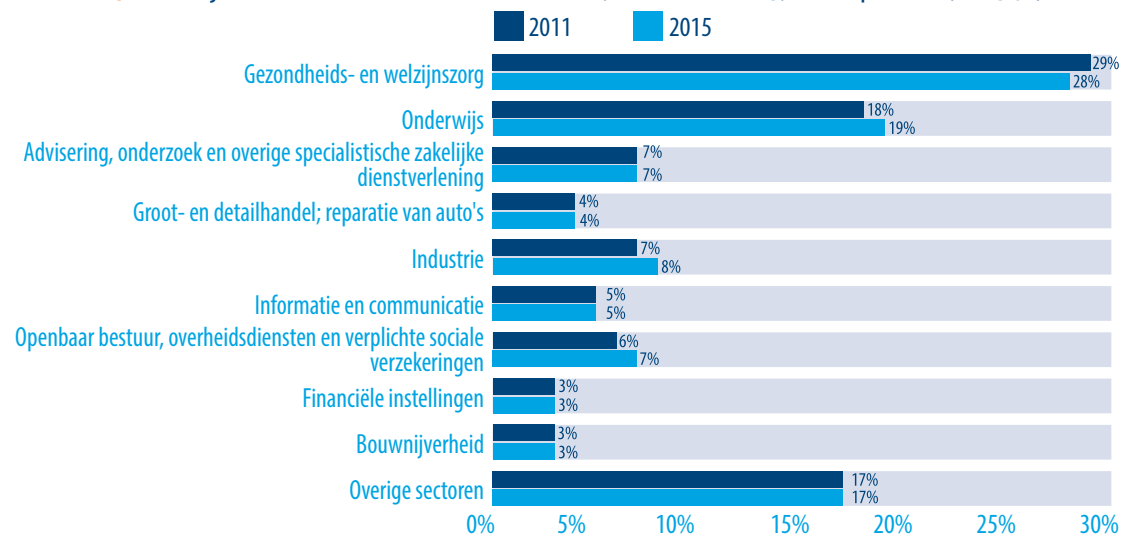

Noot. Alleen personen die in 2011 en 2015 tot werkzame beroepsbevolking behoorden.

Sectoren die hbo'ers relatief het beste weten te behouden zijn de 'Gezondheids- en welzijnszorg' en 'Onderwijs'. Dit zijn zoals we eerder zagen ook de sectoren met relatief de grootste werkgelegenheid voor hbo'ers. Bovendien zijn zowel de zorg als het onderwijs sectoren die veelal om gespecialiseerd personeel vragen (zoals verpleegkundigen en leraren). Dit personeel heeft door hun specifieke opleidingsachtergrond daarom mogelijk minder 'uitwijkmogelijkheden' naar andere sectoren. Nadere analyses op de bestemmingssectoren van de sectorwisselaars laten voor geen van de herkomstsectoren duidelijke patronen zien. Anders gesteld: er is geen sterke uitwisseling tussen sectoren onderling: 'intersectoraal mobielen' komen in allerlei sectoren terecht ${ }^{9}$.

FIGUUR 4.9 Percentage afgestudeerden dat in 2015 nog werkzaam is in dezelfde bedrijfssector als in 2011, retrospectief $(n=1548)$

Gezondheids- en welzijnszorg $(\mathrm{n}=442)$

Onderwijs ( $\mathrm{n}=285)$

Advisering, onderzoek en overige specialistische zakelijke dienstverlening $(n=116)$

Groot- en detailhandel; reparatie van auto's ( $n=61)$

Industrie $(\mathrm{n}=115)$

Informatie en communicatie $(\mathrm{n}=82)$

Openbaar bestuur, overheidsdiensten en verplichte sociale verzekeringen $(\mathrm{n}=99)$

Financiële instellingen $(n=43)$

Bouwnijverheid $(n=41)$

Overige sectoren $(\mathrm{n}=264)$

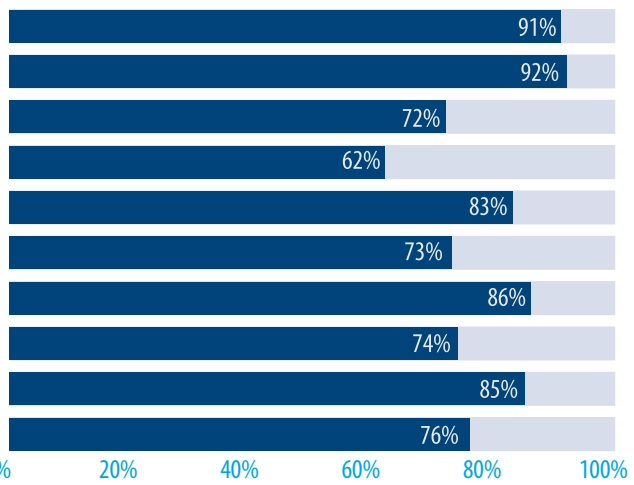

Noot. Alleen personen die in 2011 en 2015 tot werkzame beroepsbevolking behoorden.

8 De bedrijfssector uit 2011 is gebaseerd op de retrospectieve vraag 'Welk van de volgende omschrijvingen geeft het beste het bedrijf / de organisatie weer waar u destijds werkte?'

9 Vermoedelijk heeft dit deels te maken met de relatief kleine aantallen sectorwisselaars in de responsgroep enerzijds en de grote, ongespecificeerde sector 'overig' anderzijds. 


\subsection{Veranderingen in beroepsgroepen waarin afgestudeerden werkzaam zijn gedurende de eerste 5 jaar na afstuderen}

Figuur 4.10 toont het type beroep dat de afgestudeerden in 2011 en 2015 uitoefenden. In beide jaren werkte ongeveer een kwart in een 'Gezondheidszorg- en hulpverlenend beroep'. Andere beroepen waar afgestudeerden vaak in werken zijn 'Onderwijskundige beroepen' (ongeveer één op de zes), en 'Vakspecialisten / technici' (ongeveer één op de acht).Tussen 2011 en 2015 zien we bij de meeste beroepsgroepen slechts kleine verschillen in de percentages. Een grote uitzondering hierop betreffen 'Managementfuncties'. Waar in 2011 nog slechts 4 procent van de afgestudeerden in een dergelijke functie werkte, is dit in 2015 verdubbeld tot 8 procent. Deze ontwikkeling is natuurlijk niet verrassend, managementfuncties vergen veelal ruime ervaring, geavanceerde kennis en vaardigheden. Waarschijnlijk zal dit percentage in de komende jaren dan ook blijven groeien, aangezien dergelijke competenties vijf jaar na afstuderen nog volop in ontwikkeling zijn, en men zich vaak nog niet zo hoog in de bedrijfshiërarchie bevindt.

FIGUUR 4.10 Beroepsgroep waar men werkzaam in is, in 2011 en 2015, retrospectief $(n=1531)^{10}$

$$
2011 \square 2015
$$

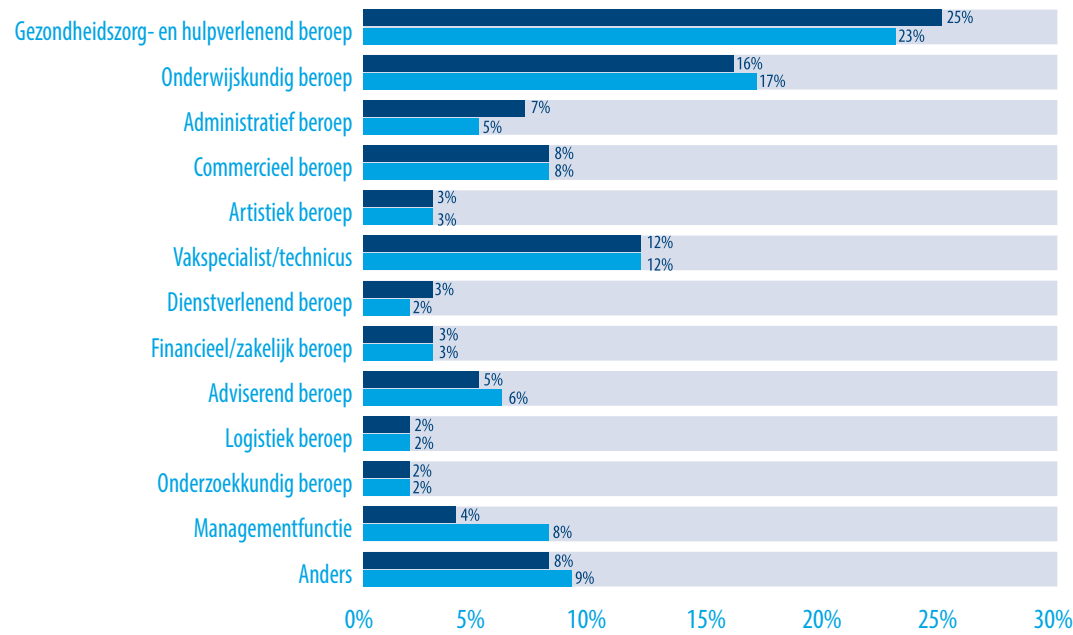

Noot. Alleen personen die in 2011 en 2015 tot werkzame beroepsbevolking behoorden.

Voorgaande figuur toont dat er tussen 2011 en 2015, met uitzondering van managementfuncties, vrij weinig verschuivingen zijn geweest in de beroepen die afgestudeerden uitoefenen. Deze percentages hebben echter betrekking op de responsgroep in zijn geheel, op individueel kunnen meer veranderingen zichtbaar zijn. Dit is inderdaad het geval zoals blijkend uit Figuur 4.11 waarin we het aandeel afgestudeerden zien dat in 2015 nog hetzelfde type beroep uitoefende als in 2011. De grootste verschuiving zien we bij de

10 De beroepsgroep uit 2011 is gebaseerd op de retrospectieve vraag 'Welk van de volgende omschrijvingen geeft het beste uw belangrijkste werkzaamheden van destijds weer?'. 
'Dienstverlenende beroepen', slechts 28 procent van de afgestudeerden die in 2011 in een dergelijk beroep werkte, is hierin in 2011 nog steeds werkzaam. Andere beroepsgroepen met veel 'uitstroom' betreffen 'Administratieve beroepen' (52\% in 2015 nog werkzaam in die beroepsgroep) en 'Logistieke beroepen' (54\%). Het is wellicht niet verwonderlijk dat deze beroepsgroepen een relatief grote uitstroom kennen, het gaat hier namelijk bovengemiddeld vaak om beroepen die niet aansluiten op de eigen opleidingsrichting en/of het opleidingsniveau. Zo gaat het bij 'Dienstverlenende beroepen' bijvoorbeeld om horecaen callcentermedewerkers: functies die men vaak tijdelijk uitoefent tijdens de zoektocht naar een baan in het eigen vakgebied.

Beroepsgroepen met een zeer lage uitstroom betreffen onder meer 'Onderwijskundige beroepen' (91\%) en 'Gezondheiszorg- en hulpverlenende beroepen' (90\%). Dit zijn veruit de grootste beroepsgroepen voor hbo'ers, waarbij het bovendien vaak gaat om zeer gespecialiseerde beroepen. De uitwijkmogelijkheden voor specialistische beroepen (zoals leraren en verpleegkundigen) naar andere beroepsgroepen zijn waarschijnlijk kleiner dan voor de meer generalistische beroepen. Ook voor de 'beroepswisselaars' is gekeken of er patronen herkenbaar zijn tussen herkomstberoepen en bestemmingsberoepen. Wederom levert dit een zeer gemengd beeld op, behalve een duidelijke doorstroom van beroepen naar managementfuncties, zien we geen duidelijke 'uitwisseling' tussen bepaalde beroepsgroepen.

FIGUUR 4.11 Percentage dat in 2015 nog werkzaam is in dezelfde beroepsgroep als in 2011, retrospectief $(n=1531)$

Gezondheidszorg- en hulpverlenend beroep ( $\mathrm{n}=377$ Onderwijskundig beroep $(\mathrm{n}=250)$ Administratief beroep $(n=108)$ Commercieel beroep ( $n=122$ Artistiek beroep ( $n=53$ ) Vakspecialist/technicus ( $\mathrm{n}=190)$ Dienstverlenend beroep ( $n=46$ ) Financieel/zakelijk beroep ( $n=47$ ) Adviserend beroep ( $\mathrm{n}=82$ ) Logistiek beroep $(n=26)$ Onderzoekkundig beroep ( $\mathrm{n}=35$ Managementfunctie $(n=66)$ Anders ( $n=129$ )

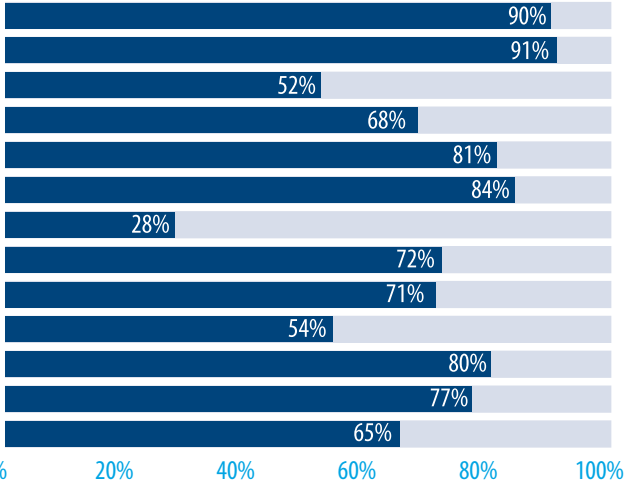

Noot. Alleen personen die in 2011 en 2015 tot werkzame beroepsbevolking behoorden.

4.6 Ontwikkelingen in leidinggeven aan medewerkers gedurende de eerste 5 jaar na afstuderen

Uit Figuur 4.12 blijkt dat er een toename van bijna 10\% is tussen 2011 en 2015 in het aandeel afgestudeerden dat aan andere medewerkers leiding geeft. Tussen de twee momenten stijgt het aandeel leidinggevenden van een zesde naar een kwart. Net als 
de toename in het aandeel 'Managers' is ook de toename in het aandeel afgestudeerden dat in 2015 leiding geeft niet verrassend. Van leidinggevenden mogen immers specifieke competenties worden verwacht (ervaring, coördinatievaardigheden et cetera) die men pas in de loop van de tijd ontwikkelt.

FIGUUR 4.12 Percentage afgestudeerden dat leiding geeft aan medewerkers, in 2011 en 2015 $(n=1738)$

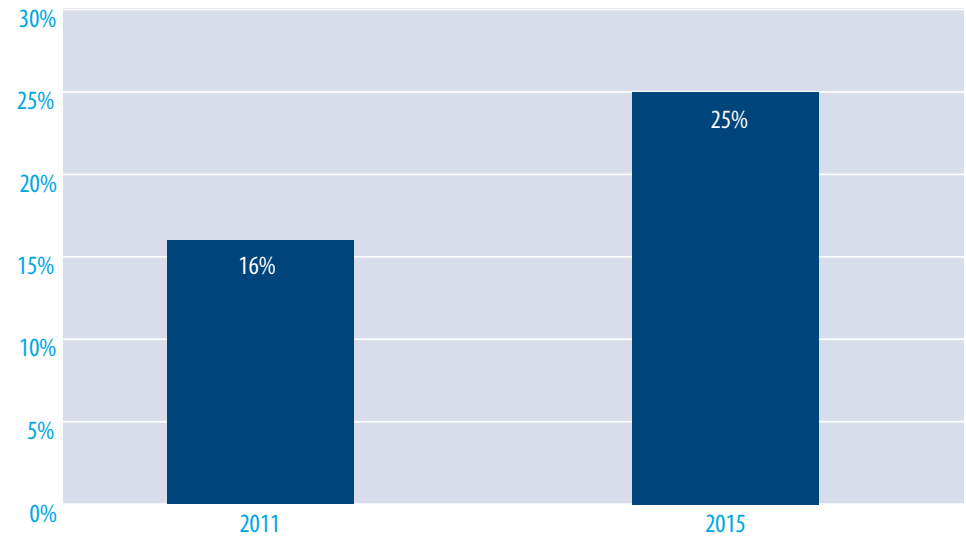

Noot. Alleen personen die in 2011 en 2015 tot werkzame beroepsbevolking behoorden.

Figuur 4.13 laat verder zien dat van de 16\% die in 2011 leiding gaf, 64\% dit anno 2015 nog steeds doet. Van degene die in 2011 nog geen leiding gaven, geeft 18\% dit in 2015 inmiddels wel.

FIGUUR 4.13 Percentage afgestudeerden dat leiding geeft aan medewerkers in 2015, naar situatie in $2011(n=1738)$

Leidinggevend in 2015

Niet leidinggevend in 2015

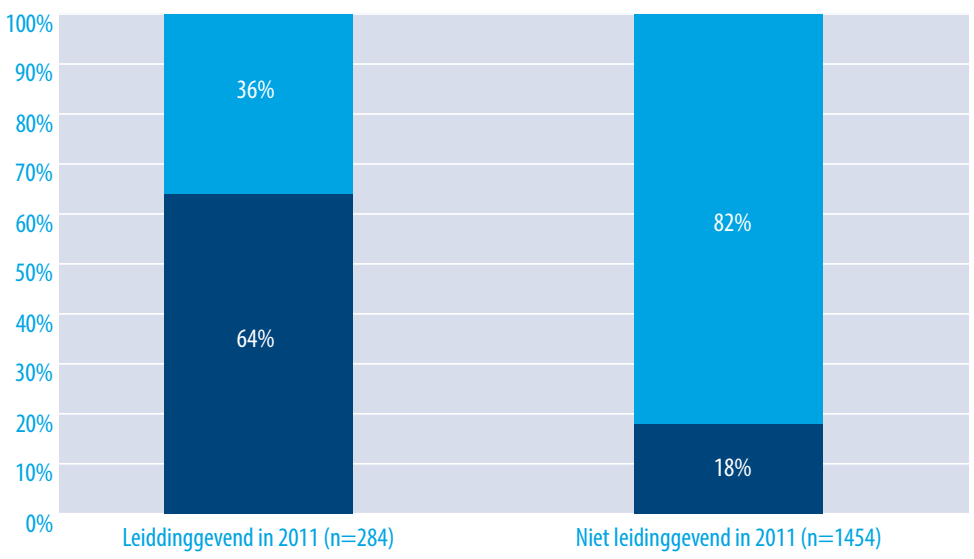

Noot. Alleen personen die in 2011 en 2015 tot werkzame beroepsbevolking behoorden 


\subsection{Ontwikkelingen in het werkzaam zijn op minimaal hbo-niveau en naar opleidingsrichting tussen 2011 en 2015}

Figuur 4.14 geeft een overzicht van de aansluiting tussen opleiding en werk qua opleidingsniveau en opleidingsrichting die vereist is voor de baan die afgestudeerden hebben ten tijde van de twee metingen. Uit deze figuur wordt allereerst duidelijk dat het aandeel afgestudeerden dat een baan heeft die zowel naar niveau als richting aansluit op de hbo-opleiding slechts licht is toegenomen tussen 2011 en 2015 (3\%). Ook het aandeel met een baan op hbo-niveau maar buiten de eigen richting is slechts licht toegenomen (1\%). Het aandeel met een baan onder hbo-niveau is daarentegen iets afgenomen (eigen/verwante richting: $-3 \%$, geen/andere richting: $-2 \%$ ), terwijl het aandeel werklozen vrijwel gelijk is gebleven. ${ }^{11}$

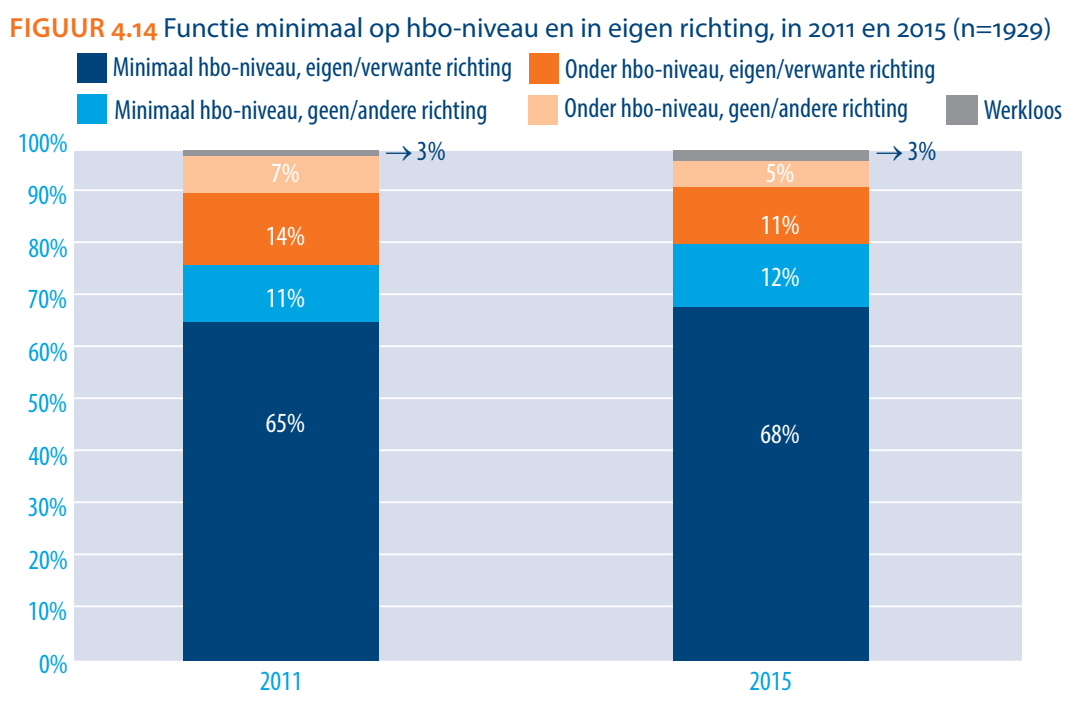

Noot. Alleen respondenten die in 2011 en in 2015 tot beroepsbevolking behoorden.

Uit Figuur 4.15 blijkt verder dat de meeste afgestudeerden die een jaar na afstuderen een baan hadden die zowel wat betreft niveau als richting aansloot op de gevolgde opleiding, dit vier jaar later nog steeds hebben (84\%). Een klein deel hiervan is uitgeweken naar een hbo-baan buiten de eigen richting (8\%), en een nog kleiner deel naar een baan onder hbo-niveau (5\%). 3\% van de afgestudeerden die in 2011 een baan op hbo-niveau en naar richting had, heeft in 2015 geen baan meer.

Van de meeste afgestudeerden die in 2011 een baan op minimaal hbo-niveau maar buiten de richting hadden, heeft vier jaar later ongeveer de helft (46\%) een baan die zowel naar niveau als richting aansluit op de gevolgde opleiding. $40 \%$ van deze groep

11 Het aandeel werklozen is hierin opgenomen omdat bij nadere analyse van de aansluiting het weglaten van deze categorie tot een misleidend beeld kan leiden. 
heeft 5 jaar na afstuderen nog steeds een baan die wel qua niveau maar niet qua richting aansluit op de gevolgde opleiding, en $7 \%$ is geswitcht en heeft nu wel een baan die qua richting aansluit, maar niet qua niveau. $6 \%$ heeft anno 2015 geen baan meer.

Van de afgestudeerden die in 2011 een baan hadden die wel aansluit qua richting, maar niet qua niveau, heeft vier jaar later $42 \%$ een baan naar niveau en richting gevonden. Ongeveer de helft heeft echter nog steeds baan die wel qua richting maar niet qua niveau bij de gevolgde opleiding aansluit en $7 \%$ heeft anno 2015 een baan die zowel qua richting als niveau niet matcht met de opleiding. 3\% zit 5 jaar na afstuderen zonder werk, en een even grote groep heeft een baan die wel past qua opleiding, maar niet qua richting.

Van de afgestudeerden die in 2011 een baan hadden die zowel qua richting als qua niveau niet aansloot op de gevolgde opleiding, heeft vier jaar later ruim een kwart een baan naar niveau en richting gevonden. Een even grote groep heeft inmiddels wel een baan naar niveau maar niet naar richting, en andere groep van gelijke grootte zit anno 2015 nog in dezelfde situatie als waar ze in 2011 zat. 15\% heeft in 2015 een baan die wel qua richting maar niet qua niveau aansluit op de gelvolgde opleiding, $6 \%$ zit zonder werk.

Interessant genoeg komen mensen die in 2011 werkloos waren, vier jaar later vaker in hbobanen terecht dan mensen die in 2011 een baan onder hbo-niveau hadden. Bijna 50\% van de werklozen in 2011 hebben in 2015 een baan naar niveau en richting, tegenover ruim een kwart van de mensen die in 2011 een baan hadden die wel qua richting maar niet qua niveau aansloot op de hbo-opleiding. Een zesde van de werklozen uit 2011 hebben anno 2015 wel een baan op niveau maar niet naar richting, en ongeveer een gelijk aandeel werklozen uit 2011 heeft anno 2015 een baan die qua richting en niveau niet aansluit op de gevolgde opleiding en of is nog steeds werkloos. 10\% van de werklozen uit 2011 heeft 4 jaar later een baan die wel aansluit qua richting maar niet naar niveau.

Samenvattend laat voorgaande figuur zien dat de situatie in 2011 en 2015 behoorlijk sterk aan elkaar gerelateerd zijn. Er zijn weliswaar veel (vooral opwaartse) verschuivingen waarneembaar, maar we zien ook dat de kans om in 2015 op hbo-niveau dan wel in de eigen richting te werken sterk samenhangt met de positie in 2011. Een mogelijke verklaring hiervoor ligt waarschijnlijk in de individuele eigenschappen van afgestudeerden. De eigenschappen die een afgestudeerde in 2011 geschikt maakten voor een bepaalde functie (en mogelijk minder geschikt voor andere functies), zullen in 2015 deels nog steeds de eigenschappen zijn die iemand voor een bepaalde functie meer of minder geschikt maken. Een heel andere verklaring kan zijn dat men door het opdoen van ervaring in een specifiek type werk minder 'uitwijkmogelijkheden' naar andere functies heeft (die mogelijk beter 'matchen' met de vooropleiding). Het spectrum aan potentiële banen is kort na afstuderen doorgaans breder dan wanneer men al een aantal jaar in een bepaalde functie heeft gewerkt (Theeuwes, 2008).

Figuur 4.16 geeft tot slot een overzicht van de aansluiting in 2011 en 2015 per opleidingssector. Te zien is dat doorstroom naar werk op hbo-niveau het sterkst is toegenomen 
in de sectoren waar dit aandeel in 2011 het laagst was: Landbouw, Economie en Taal \& Cultuur. Vooral in de sectoren Landbouw en Economie gaat het om een sterke toename in banen op hbo-niveau maar buiten de eigen richting. In de sectoren Onderwijs, Techniek en Gezondheidszorg, waar de aansluiting in 2011 meestal erg goed was, is betrekkelijk weinig veranderd.

FIGUUR 4.15 Vereiste richting en niveau van functie in 2015, naar vereiste richting en niveau van functie in $2011(n=1929)$

Minimaal hbo-niveau, eigen/verwante richting in 2015 Onder hbo-niveau, eigen/verwante richting in 2015

Minimaal hbo-niveau, geen/andere richting in 2015 Onder hbo-niveau, geen/andere richting in 2015

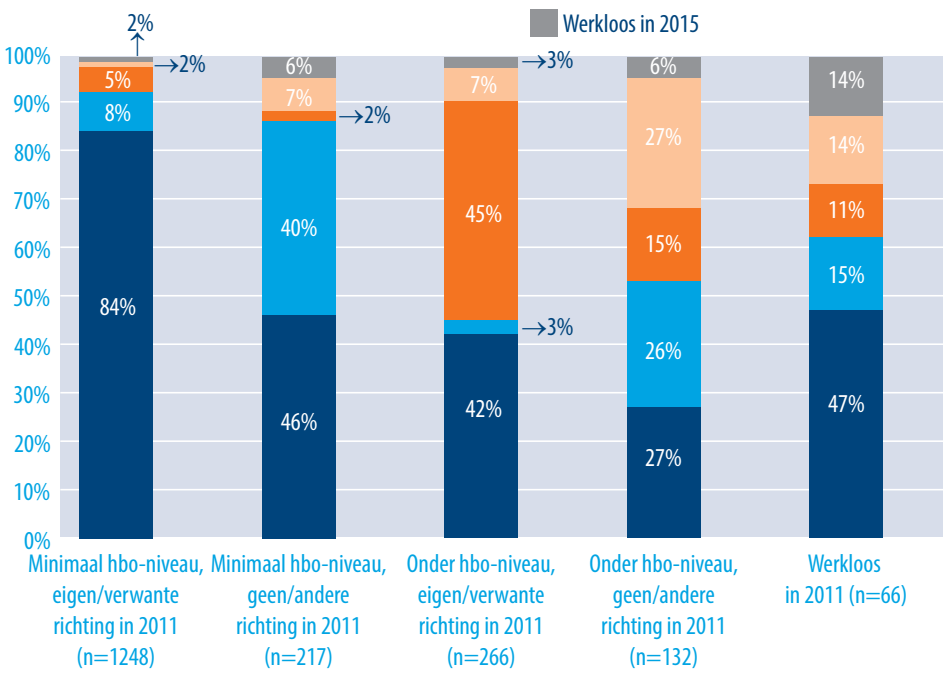

Noot. Alleen respondenten die in 2011 en in 2015 tot beroepsbevolking behoorden.

FIGUUR 4.16 Minimaal werkzaam op hbo-niveau, in 2011 en 2015, naar sector, voltijd ( $n=1429$ )

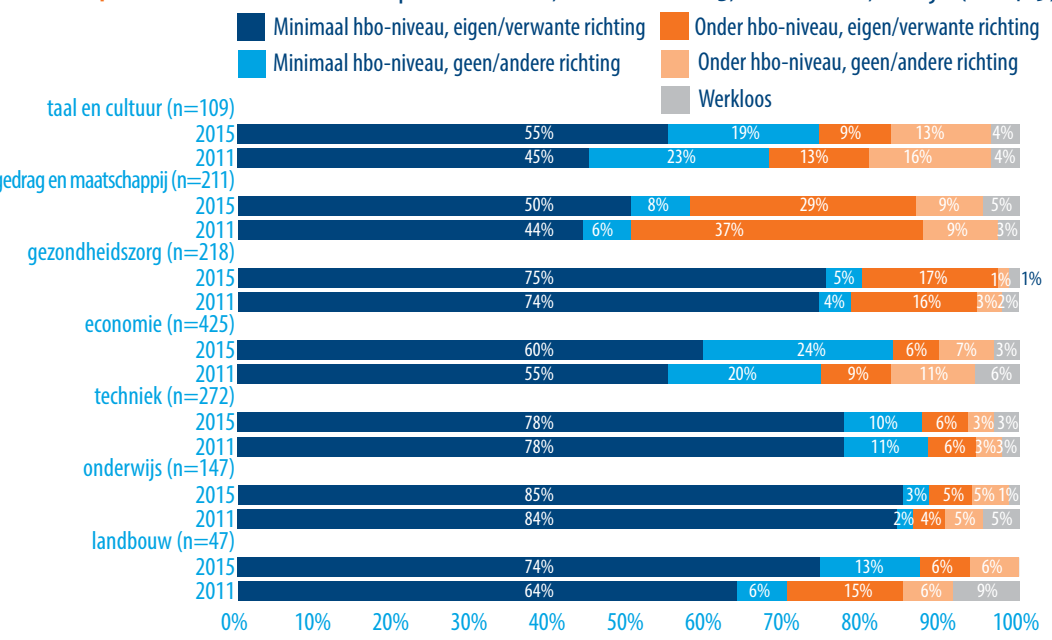

Noot: Alleen respondenten die in 2011 en in 2015 tot beroepsbevolking behoorden. 


\subsection{Ontwikkelingen in de competentietekorten en -overschotten van afgestudeerden tussen 2011 en 2015}

We kunnen de aansluiting tussen onderwijs en arbeidsmarkt ook nader bekijken in termen van competenties. In beide vragenlijsten is aan de hand van een uitgebreide lijst van competenties aan de respondenten gevraagd zowel het eigen niveau als het niveau dat vereist is in de huidige functie te beoordelen op een 5-puntsschaal. Hoewel de absolute competentiescores niet direct vergelijkbaar zijn omdat respondenten in de loop van de jaren hun normen kunnen hebben bijgesteld, kunnen de verschilscores tussen het eigen en het vereist niveau wel gebruikt worden om meer zicht te krijgen op eventuele tekorten en overschotten. ${ }^{12}$ Figuur 4.17 laat dit zien voor vier geselecteerde competenties, te weten kennis van eigen vakgebied (een indicator van vakkennis), logisch redenen (analytische vaardigheden), conform budget, planning en richtlijnen werken (planmatig werken), en ideeën en oplossingen bedenken (innovatie/creativiteit). Uit de figuur blijkt dat vooral voor vakkennis de match tussen eigen en vereist niveau verbeterd is tussen 2011 en 2015. Het percentage van zowel tekorten als overschotten is behoorlijk afgenomen. Bij de overige competenties is ook een afname te zien in het aandeel tekorten, maar niet in het aandeel overschotten. Er is zelfs een lichte toename in overschotten van competenties op het gebied van innovatie/creativiteit.

De afname van het aandeel competentietekorten is in lijn met de verwachting. Immers houdt het werken aan de eigen competenties niet op wanneer men afstudeert. Sterker nog: "Het is [...] een illusie om te denken dat alle investeringen in menselijk kapitaal [...] kunnen plaatsvinden voordat iemand toetreedt tot de arbeidsmarkt." (Borghans e.a., 2014). Hoewel we niet kunnen meten of en in hoeverre competenties zich absoluut hebben ontwikkeld, geven de afnemende (gepercipieerde) tekorten wel een indicatie dat men is blijven doorleren. Daarnaast kan een betere competentiematch ook ontstaan door een baan te vinden die sterker bij de eigen competenties aansluit. Tijdens de loopbaan is het dan ook te verwachten dat mensen steeds meer in banen terechtkomen waarbij hun sterke kanten (beter) benut worden en hun zwakkere kanten (relatief) minder belemmerend zijn.

12 De sector Taal \& Cultuur heeft geen gebruik gemaakt van deze competentiemeting, en wordt daarom buiten beschouwing gelaten bij deze analyses. 
FIGUUR 4.17 Aansluiting tussen de eigen en vereiste competenties, in 2011 en 2015 2011 2015

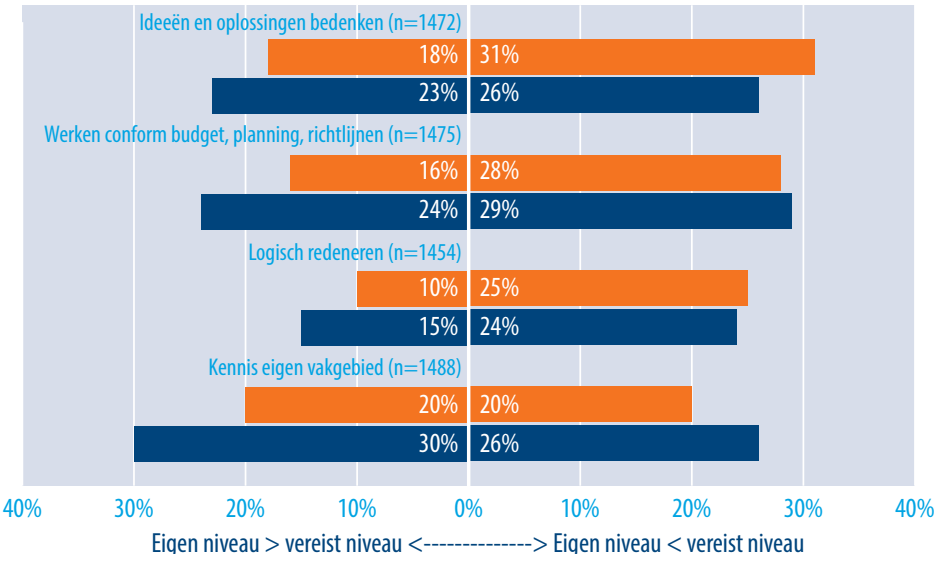

Noot. Alleen respondenten die in 2011 en in 2015 tot werkzame beroepsbevolking behoorden.

Figuren $4.18 \mathrm{t} / \mathrm{m} 4.21$ laten zien hoe deze aansluiting naar competenties zich per sector heeft ontwikkeld. Figuur 4.18 laat zien dat de aansluiting naar vakkennis verbeterd is in de sectoren Landbouw, Techniek, Economie en Gedrag \& Maatschappij, in de laatste twee vooral in de vorm van een reductie in overschotten. In de sectoren Onderwijs en Gezondheidszorg is een forse vermindering in het aandeel tekorten te zien, maar dit is gepaard gegaan met een toename in overschotten. Bij de overige competenties (zie Figuur $4.19 \mathrm{t} / \mathrm{m} \mathrm{4.21)}$ is slechts voor een klein aantal sectoren een duidelijke verbetering te zien in de aansluiting in termen van een reductie van zowel tekorten als overschotten. Bij logisch redeneren (analytische competenties) geldt dit voor de sectoren Economie en Gedrag \& Maatschappij, bij planmatig werken alleen voor de sector Economie, en bij ideeën en oplossingen bedenken (innovatie/creativiteit) voor Landbouw en (nogmaals) Economie. De sector Economie geldt dus als enige sector waar ondubbelzinnig een verbetering te zien is in de match op alle vier competenties. In de overige sectoren is een het tekort meestal ingeruild voor een groter overschot. 
FIGUUR 4.18 Aansluiting tussen de eigen kennis over het 'eigen vakgebied' en vereiste kennis over het 'eigen vakgebied', in 2011 en 2015

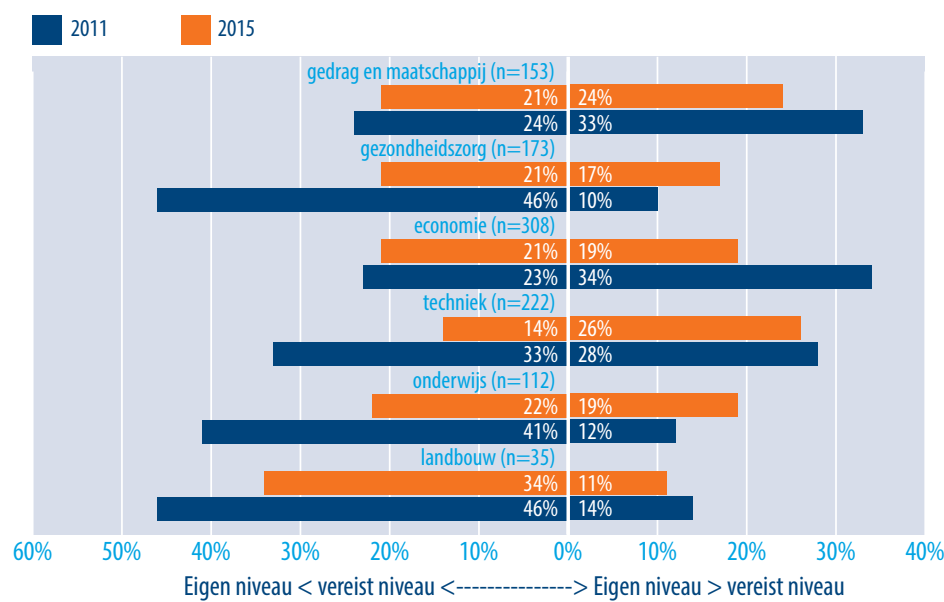

Noot. Alleen respondenten die in 2011 en in 2015 tot werkzame beroepsbevolking behoorden.

FIGUUR 4.19 Aansluiting tussen de eigen kennis over 'logisch redeneren' en vereiste kennis over 'logisch redeneren', in 2011 en 2015

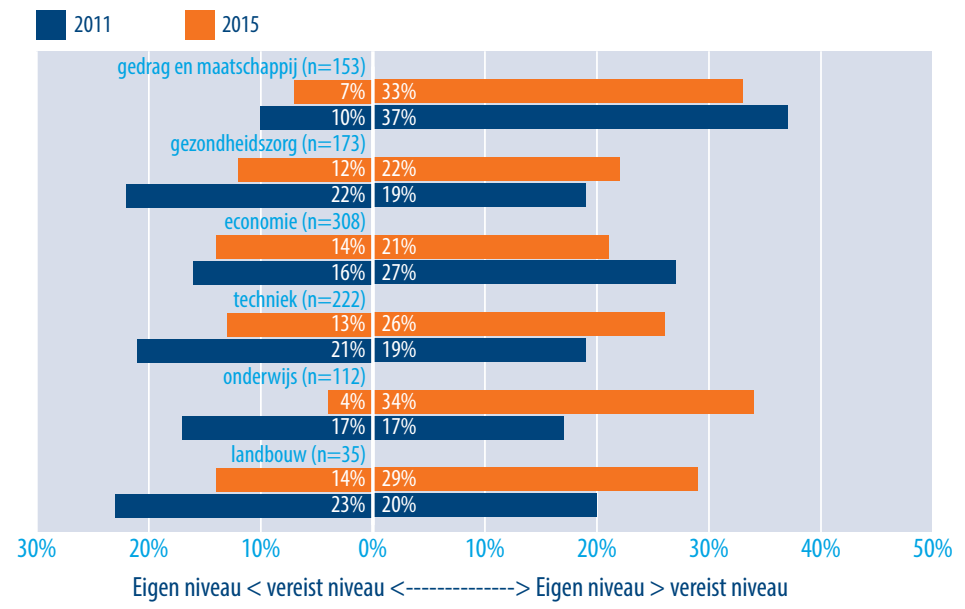

Noot. Alleen respondenten die in 2011 en in 2015 tot werkzame beroepsbevolking behoorden. 
FIGUUR 4.20 Aansluiting tussen de eigen kennis over 'werken conform budget, planning, richtlijnen' en vereiste kennis over 'werken conform budget, planning, richtlijnen', in 2011 en 2015

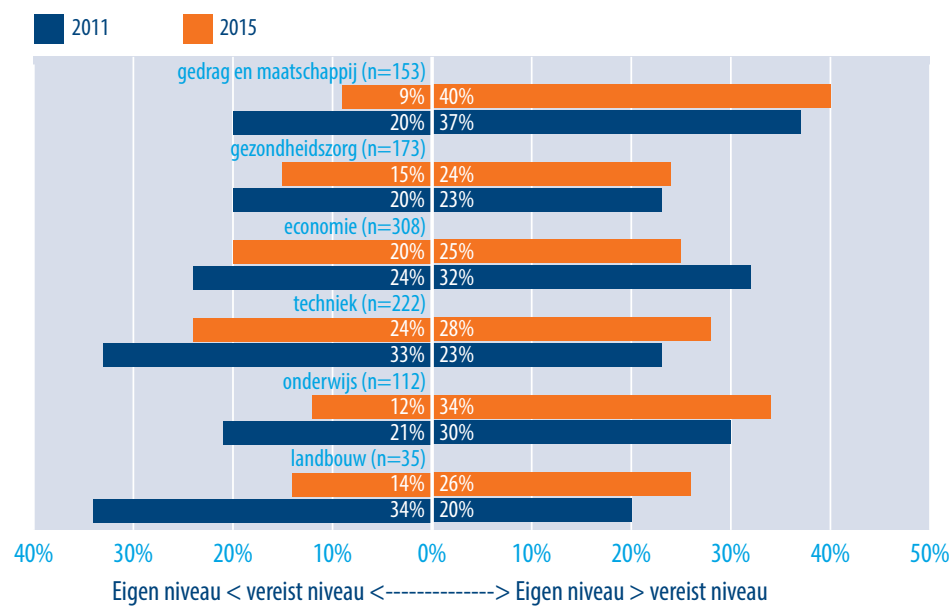

Noot. Alleen respondenten die in 2011 en in 2015 tot werkzame beroepsbevolking behoorden.

FIGUUR 4.21 Aansluiting tussen de eigen kennis over 'ideeën en oplossingen bedenken' vereiste kennis over 'ideeën en oplossingen bedenken', in 2011 en 2015

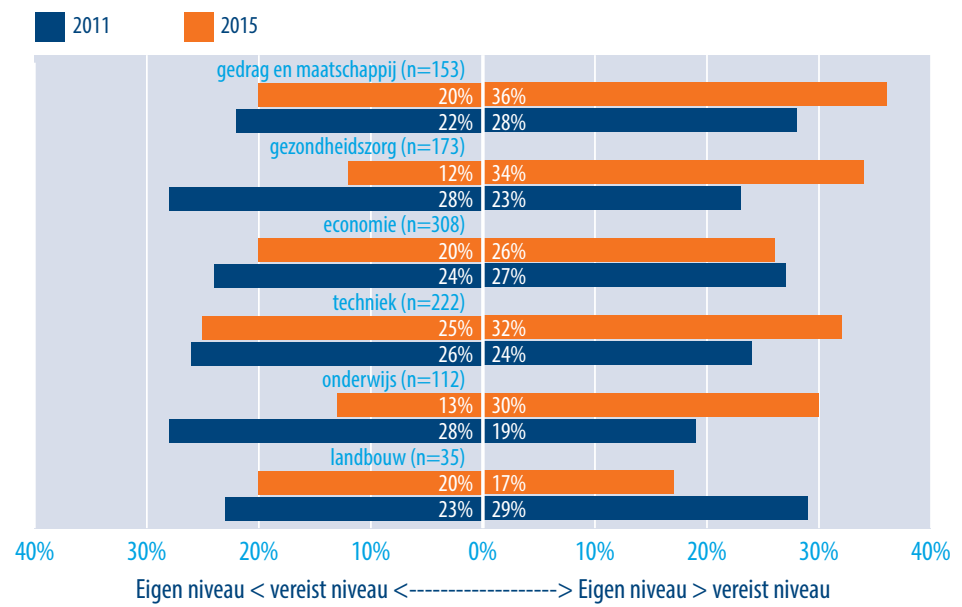

Noot. Alleen respondenten die in 2011 en in 2015 tot werkzame beroepsbevolking behoorden. 


\subsection{Ontwikkelingen in de beoordeling van carrièremogelijkheden tussen 2011 en 2015}

Figuur 4.22 laat zien hoe werkende afgestudeerden hun carrièremogelijkheden beoordelen één en vijf jaar na afstuderen. Over de gehele linie verandert hierin weinig in de loop van de tijd. Er is zelfs een lichte afname in het aandeel dat vindt dat hun baan goede carrièremogelijkheden biedt (-3\%). Op zich is het niet verwonderlijk dat de carrièreperspectieven naarmate men meer ervaring opdoet op de arbeidsmarkt niet verder verbeteren, maar juist voorzichtig afnemen. Aan het prille begin en in de eerste paar jaar van de loopbaan zijn de loopbaanmogelijkheden waarschijnlijk het grootst. Zo kennen veel werkgevers 'juniorfuncties' waarin de nieuwkomer aan de omgeving en het type werk kan wennen, waarna men na enkele jaren ervaring kan doorstromen naar een meer zelfstandige, hogere functie. Verdere doorstroom vanuit een dergelijke functie kan dan moeilijker zijn.

Uit nadere analyse (hier niet getoond) blijkt dat deze afname terug te zien is bij afgestudeerden van zowel voltijd als deeltijd/duale opleidingen. Op beide meetmomenten zijn afgestudeerden van voltijd-opleidingen echter wel meer tevreden over hun actuele carrièremogelijkheden dan afgestudeerden van deeltijd/duale opleidingen.

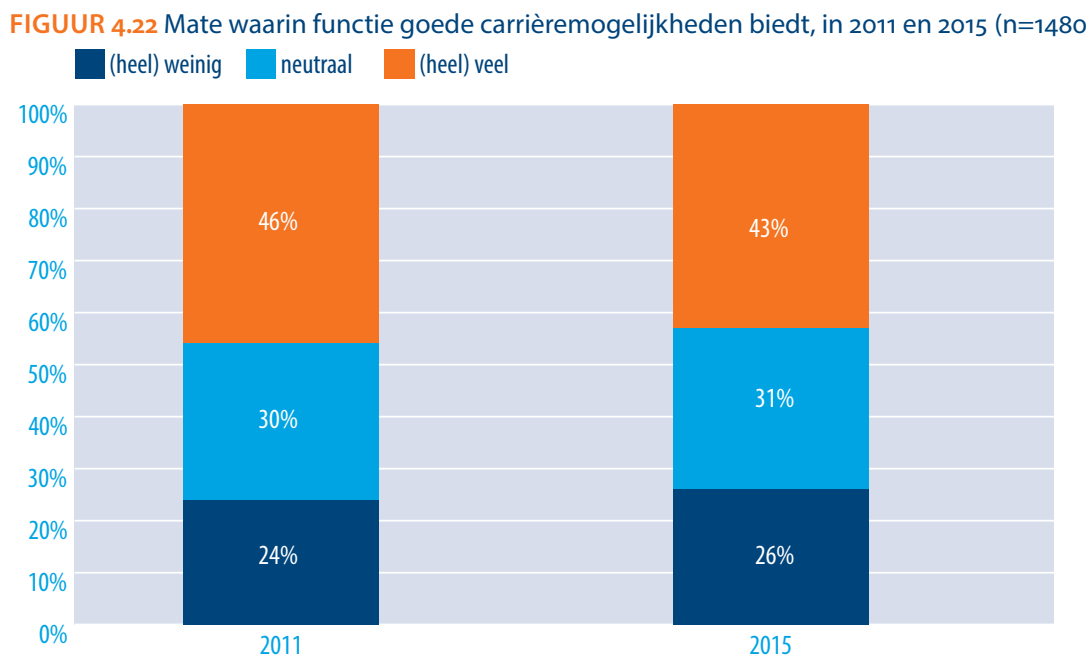

Noot. Alleen respondenten die in 2011 en in 2015 tot werkzame beroepsbevolking behoorden.

Figuur 4.23 laat verder zien dat de carrièremogelijkheden het sterkst afgenomen zijn onder afgestudeerden van de sectoren Landbouw, Gezondheidszorg en Techniek. In de sector Onderwijs is sprake van een lichte verbetering, hoewel in absolute zin deze sector de minste carrièremogelijkheden vertoont. 
FIGUUR 4.23 Percentage dat (heel) veel carrièremogelijkheden heeft in functie, in 2011 en 2015, naar sector, voltijd $(n=1090)$

2011

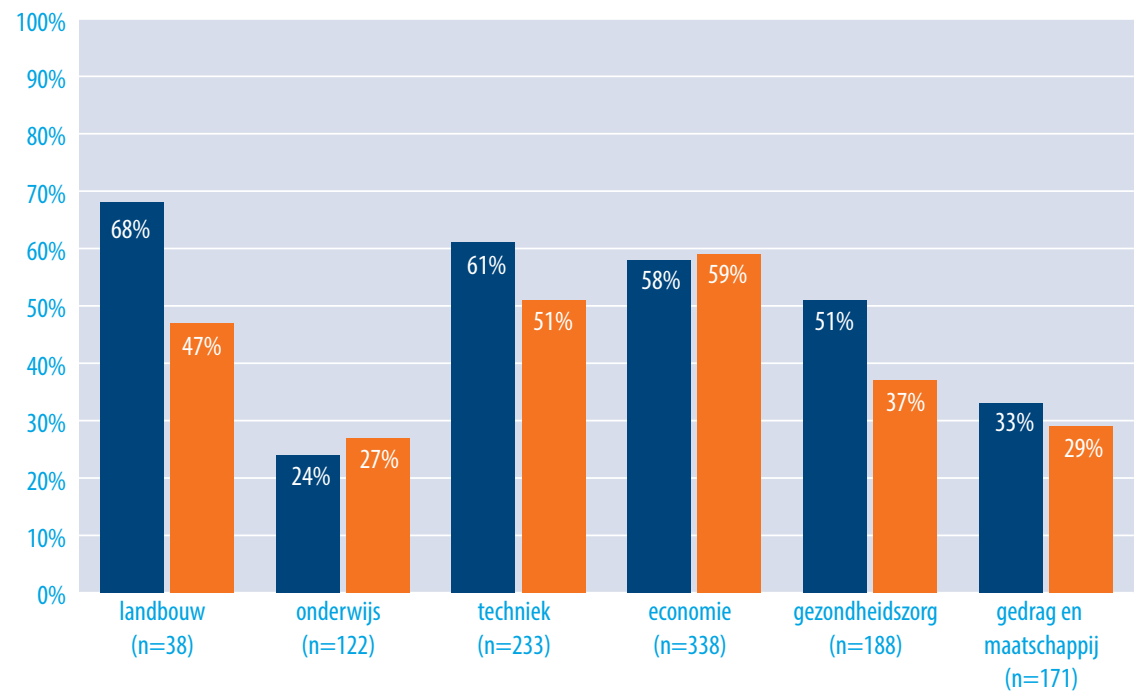

Noot. Alleen respondenten die in 2011 en in 2015 tot werkzame beroepsbevolking behoorden, exclusief de sector Taal \& Cultuur'.

FIGUUR 4.24 Mate waarin functie in 2015 goede carrièremogelijkheden biedt, naar oordeel in 2011 $(n=1480)$

(heel) weinig in 2015

neutraal in 2015

(heel) veel in 2015

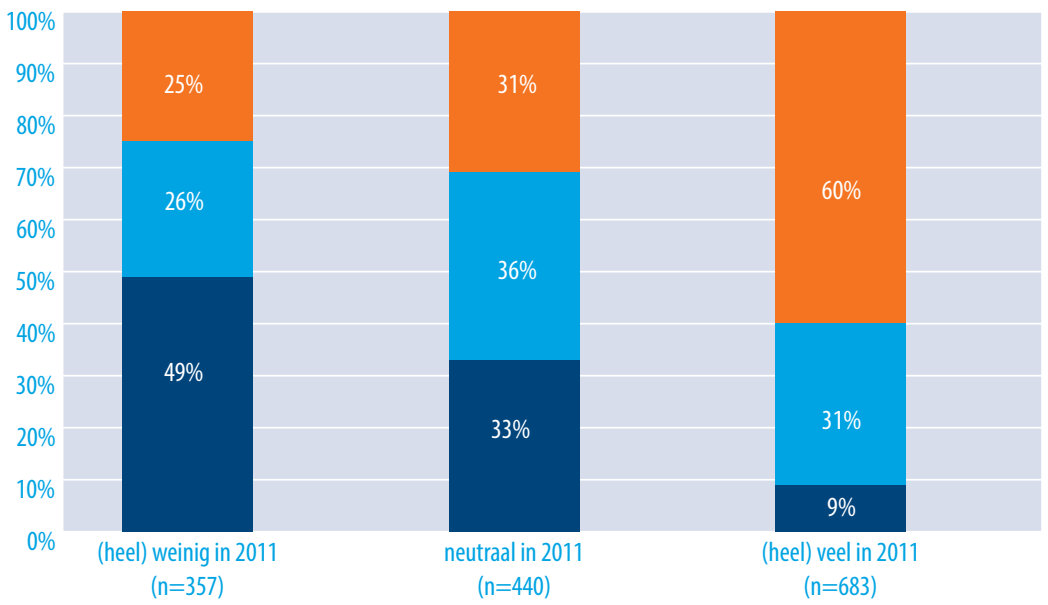

Noot. Alleen respondenten die in 2011 en in 2015 tot werkzame beroepsbevolking behoorden. 
In Figuur 4.24 is tot slot te zien dat er een duidelijke samenhang is tussen de gepercipieerde carrièremogelijkheden in 2011 en die in 2015. Van de afgestudeerden die in 2011 (heel) weinig carrièremogelijkheden in hun functie ervoeren, vindt de helft (49\%) dat hun carrièremogelijkheden in 2015 nog steeds beperkt zijn. Een kwart (26\%) is in 2015 'neutraal' en weer een kwart (25\%) heeft inmiddels (naar eigen inschatting) goede carrièremogelijkheden. Als we kijken naar de afgestudeerden die in 2011 (heel) veel carrièremogelijkheden in hun functie ervoeren, dan blijkt zes op de tien afgestudeerden (60\%) ook in 2015 goede perspectieven te hebben. Drie tiende van hen (31\%) is in 2015 'neutraal' over de mogelijkheden, en slechts één op de tien ( $9 \%$ ) vind de carrièremogelijkheden beperkt. Er zijn in algemene zin dus redelijk veel 'verschuivingen' geweest naar meer / minder carrièremogelijkheden, maar de ervaren mogelijkheden in 2011 hangen wel sterk samen met de ervaren mogelijkheden in 2015.

\subsection{Ontwikkelingen in baantevredenheid tussen 2011 en 2015}

Figuur 4.25 laat zien dat er ook sprake is van een lichte daling in de baantevredenheid van werkende afgestudeerden $(-4 \%)$. Hoewel vanuit het idee van baanwisselingen verwacht zou kunnen worden dat men via mobiliteit in aantrekkelijkere functies terecht komt, is uit de literatuur ook bekend dat baantevredenheid vaak een 'U-vormig'verband met leeftijd kent (o.a. Clark, Oswald \& Warr, 1996). Dat wil zeggen dat personen aan het begin van de loopbaan behoorlijk tevreden zijn, vervolgens steeds minder tevreden zijn, en later (veelal tussen de 30 en 35) weer meer tevreden worden. De aanvankelijke daling in tevredenheid wordt mogelijk veroorzaakt doordat men na enkele jaren beter vergelijkingsmateriaal heeft (andere banen blijken aantrekkelijker dan de eigen baan) of omdat men tot de conclusie kan komen dat men de oorspronkelijke ambities niet waar heeft kunnen maken. De latere stijging in de baantevredenheid heeft mogelijk te maken met een groter relativeringsvermogen of verschuiving van waarden (bijvoorbeeld minder belang aan doorgroeimogelijkheden).

Uit Figuur 4.26 blijkt verder dat de daling in tevredenheid het sterkst is in de sectoren Landbouw en Gezondheidszorg. Afgestudeerden van de sector Economie zijn daarentegen juist iets tevredener in 2015 dan in 2011. Mogelijk heeft de toegenomen tevredenheid daar te maken met de relatief hoge lonen en goede (gepercipieerde) carrièremogelijkheden. 
FIGUUR 4.25 Mate waarin afgestudeerden tevreden zijn met huidige functie, in 2011 en 2015 ( $n=1554$ )

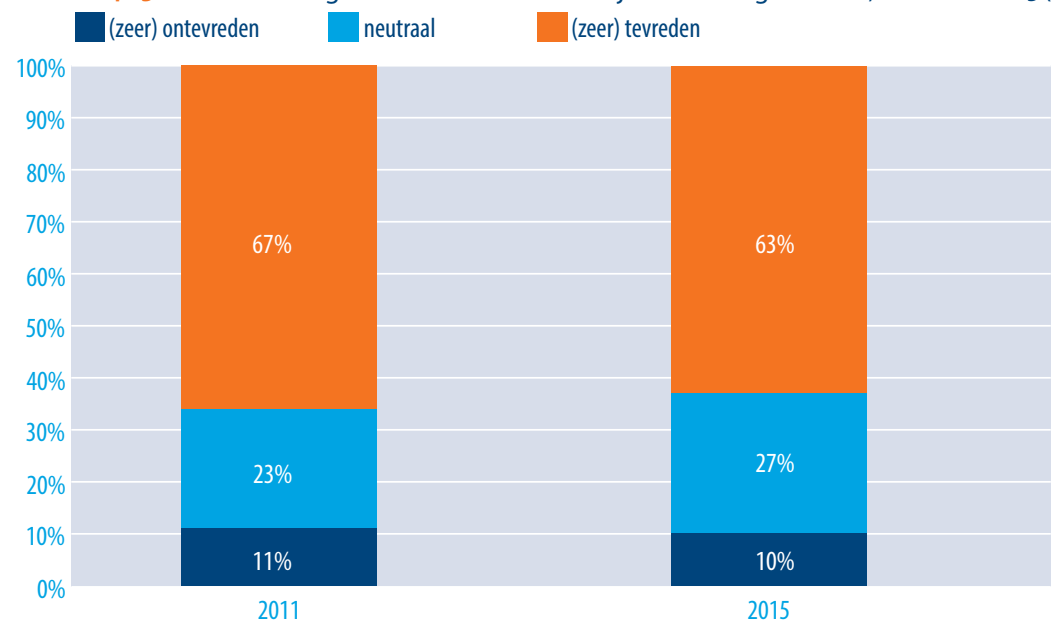

Noot. Alleen respondenten die in 2011 en in 2015 tot werkzame beroepsbevolking behoorden.

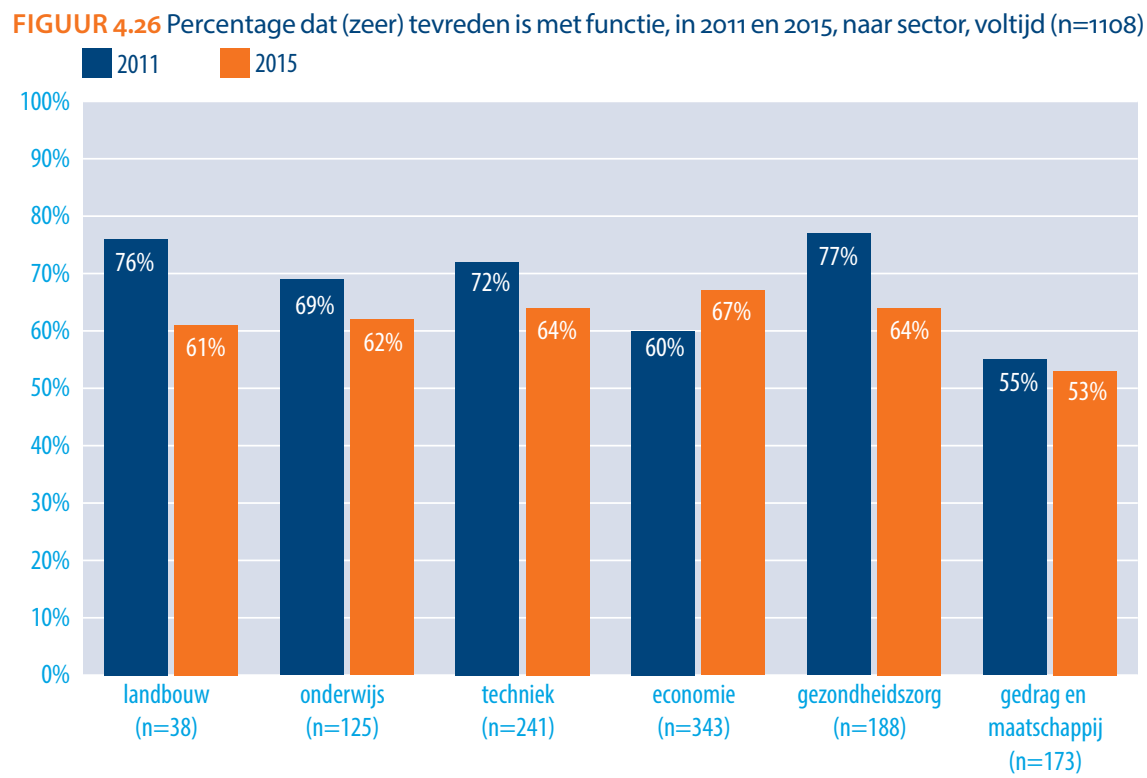

Noot. Alleen respondenten die in 2011 en in 2015 tot werkzame beroepsbevolking behoorden, exclusief de sector Taal \& Cultuur.

De tevredenheid over de functie in 2011 hangt weliswaar samen met de tevredenheid in 2015, maar tegelijkertijd zijn er ook veel verschuivingen in de oordelen, zo is te zien in Figuur 4.27. Afgestudeerden die in 2011 (zeer) ontevreden over hun baan waren, hebben een grotere kans om ook in 2015 ontevreden te zijn dan andere afgestudeerden. Ruim 
een op de vijf'ontevredenen' in 2011, is in 2015 wederom ontevreden over de baan. Dit is fors hoger dan onder de 'tevredenen' in 2011 (8\% ontevreden in 2015). Echter, maar liefst de helft van de afgestudeerden die in 2011 ontevreden waren, is in 2015 wél tevreden over de functie. Ook onder degenen die in 2011 'neutraal' waren over de functie, is de helft (48\%) in 2015 tevreden. Afgestudeerden die in 2011 tevreden waren, zijn dit voor het overgrote deel (70\%) nog steeds in 2015. Een kwart is van'tevreden' naar'neutraal'gegaan en, zoals al besproken, minder dan één tiende (8\%) is in 2015 ontevreden geworden.

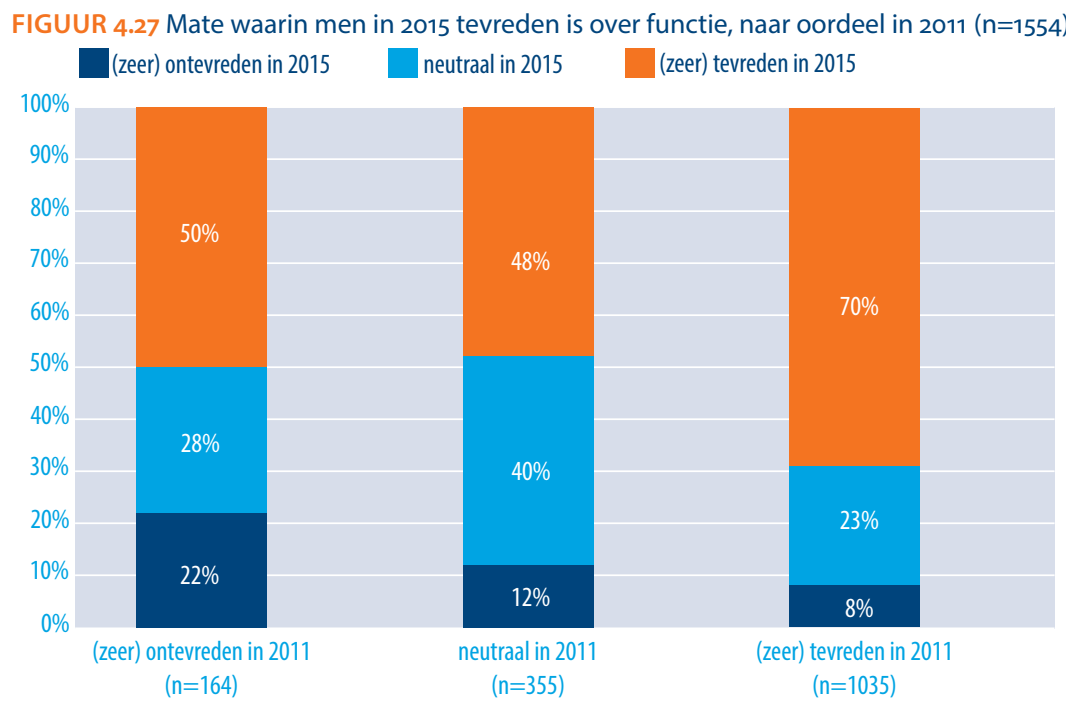

Noot. Alleen respondenten die in 2011 en in 2015 tot werkzame beroepsbevolking behoorden.

\subsection{Ervaren werkdruk in 2015}

Enkel in 2015 zijn afgestudeerden bevraagd in welke mate zij werkdruk ${ }^{13}$ ervaren in hun huidige baan. Figuur 4.28 toont per opleidingssector het aandeel afgestudeerden dat relatief veel werkdruk ervaart (dat wil zeggen een gemiddelde schaalscore van 3,5 of hoger). Afgestudeerden van de sectoren Onderwijs en Taal \& Cultuur ervaren het vaakst (ongeveer één op de drie respondenten) een hoge werkdruk in hun werk, vijf jaar na afstuderen. Afgestudeerden in de sectoren Gezondheidszorg en Gedrag \& Maatschappij ervaren gemiddeld de minste werkdruk.

De hoge werkdruk onder afgestudeerden uit de hbo-sector Onderwijs is in lijn der verwachting. Over de arbeidsmarktsector Onderwijs is immers bekend dat hier rela-

13 Deze schaal (Cronbach's alpha $=0,82$ ) bestaat uit 8 items, waarvan minimaal 7 beantwoord moeten zijn: a) $\mathrm{Er}$ is vaak grote tijdsdruk door een hoge werkbelasting; b) Het gebeurt vaak dat ik al bij het wakker worden aan werkproblemen denk; c) Als ik thuis kom, kan ik mijn werk heel makkelijk van me afzetten; d) Degenen, die mij het dierbaarst zijn, zeggen dat ik me te veel voor mijn werk opoffer; e) Het werk laat me zelden los, zelfs 's avonds spookt het nog door mijn hoofd; f) Als ik iets uitstel dat ik eigenlijk vandaag had moeten doen, kan ik 's nachts niet slapen; g) Tijdens mijn werk word ik vaak gestoord en onderbroken. 
tief veel werkdruk ervaren wordt en er een hoog verzuim is (o.a. CBS Statline). De hoge ervaren werkdruk bij afgestudeerden uit Taal \& Cultuur is wellicht opvallender. Uit onderzoek (Smulders \& Houtman, 2004) is bekend dat werkdruk vooral samenhangt met complex, onvoorspelbaar, zwaar en repeterend, emotioneel, en leidinggevend werk. Mogelijk hebben afgestudeerden uit de sectoren Onderwijs en Taal \& Cultuur met enkele van deze aspecten relatief vaker te maken.

FIGUUR 4.28 Percentage met hoge werkdruk (schaalscore van 3,5 of hoger), in 2015, naar sector, voltijd $(n=1488)$

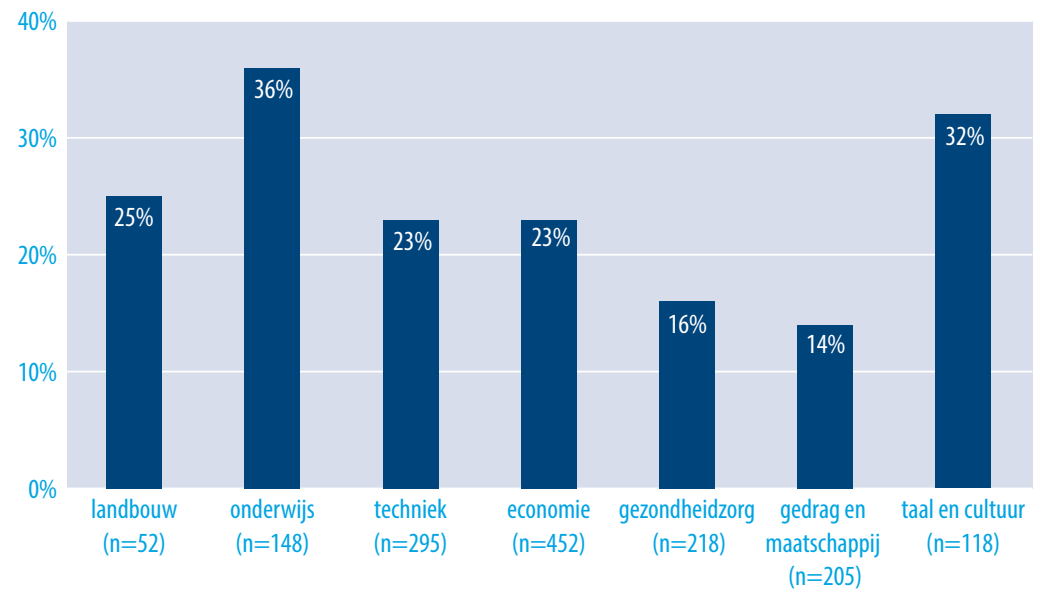

Noot. Alleen respondenten die in 2015 tot werkzame beroepsbevolking behoorden.

\subsection{Ontwikkelingen in het werken als zelfstandige tussen 2011 en 2015}

Het aandeel zelfstandigen verandert nauwelijks tussen 2011 en 2015 (zie Figuur 4.29). Er is sprake van een stijging van slechts $0,3 \%$. Uit Figuur 4.30 volgt dat er onder afgestudeerden uit de opleidingssector Taal \& Cultuur veel meer zelfstandigen werken dan gemiddeld. Wel is het aandeel zelfstandigen onder afgestudeerden uit Taal \& Cultuur tussen 2011 en 2015 fors afgenomen, van ongeveer zes op de tien (58\%) naar vier op de tien (38\%). Wellicht heeft dit te maken met de forse bezuinigingen in de cultuursector (onder andere door afbouw van subsidies) vanaf $2013^{14}$, waardoor (voortzetting van) eigen initiatieven van kunstenaars moeilijker zijn geworden. Een andere opleidingssector die relatief veel zelfstandigen heeft voortgebracht (hoewel alsnog veel minder dan Taal \& Cultuur) betreft Landbouw. Hier is juist een toename in het aandeel zelfstandigen te zien, waar in 2011 vrijwel geen van de Landbouw-afgestudeerden zelfstandige was, betrof het in 2015 bijna

14 "De rijksoverheid bezuinigt conform het regeerakkoord van het kabinet Rutte I met ingang van 2013 in totaal 200 miljoen euro op de culturele sector. Deze bezuiniging is deels ingevuld door het stopzetten van subsidieregelingen en andere posten. Ook is er een generieke bezuiniging op de gehele cultuurbegroting doorgevoerd van 2,2\% incidenteel in 2011 en 5\% structureel vanaf 2012." Kamerbrief OCW 24 december 2013. 
13 procent. Vermoedelijk gaat het hier vooral om afgestudeerden die na enkele jaren een eigen landbouwbedrijf starten of een bedrijf overnemen.

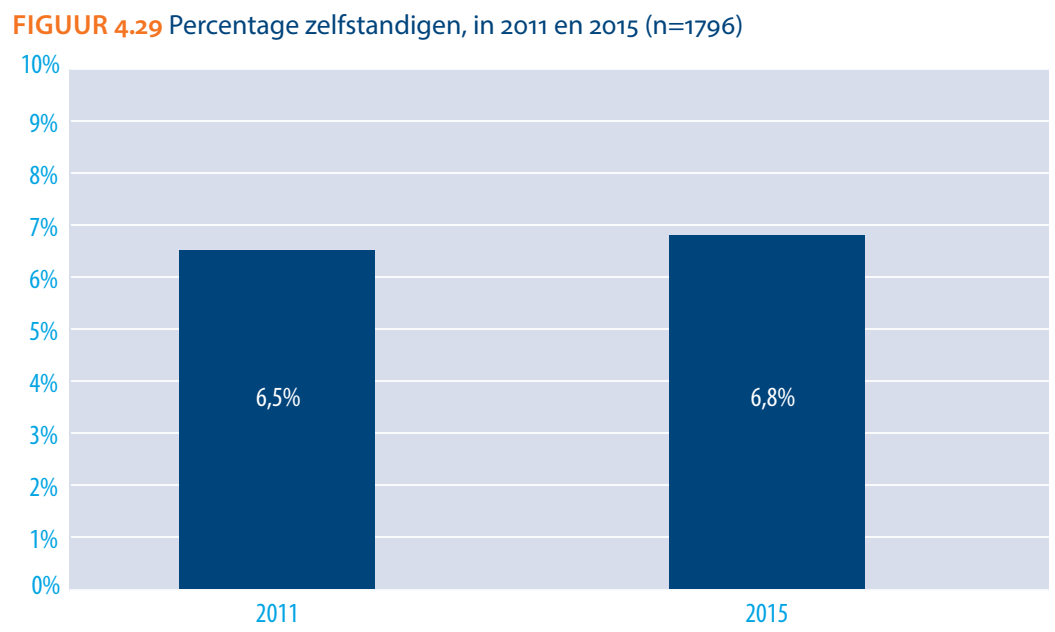

Noot. Alleen respondenten die in 2011 en in 2015 tot werkzame beroepsbevolking behoorden. Onder 'zelfstandigen' worden ook meewerkende gezinsleden gerekend. Exclusief dienstverband 'anders'

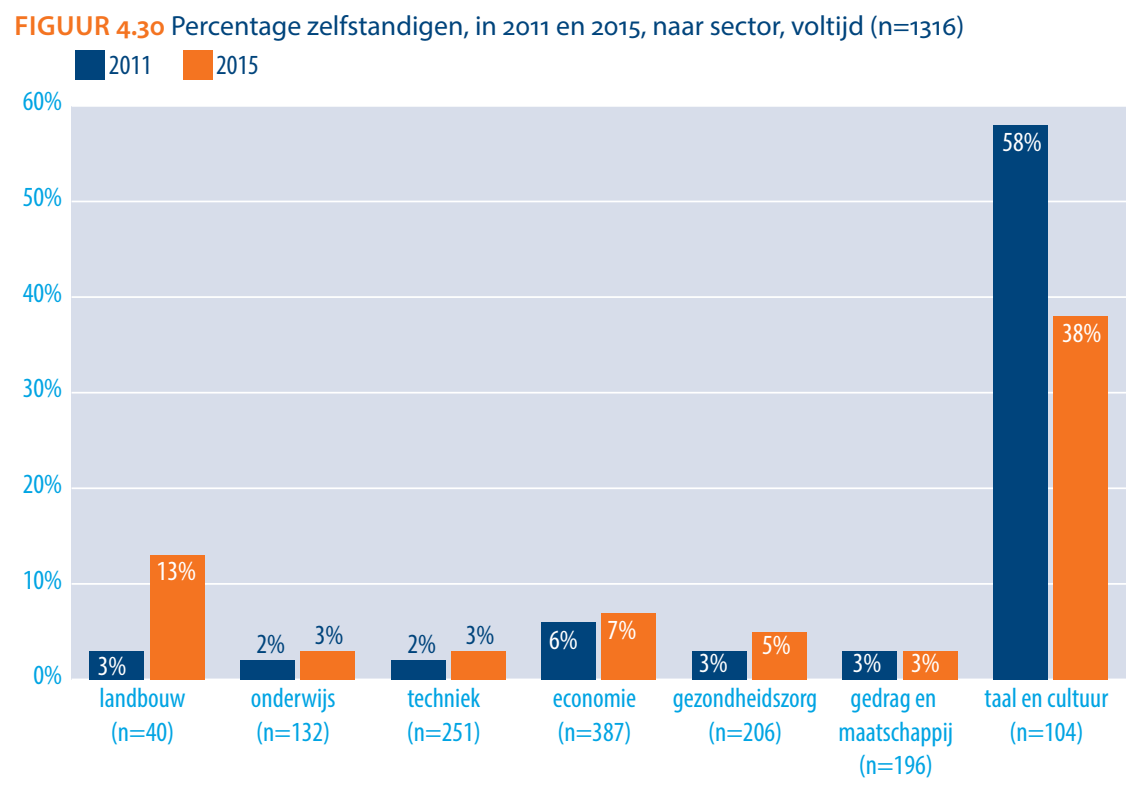

Noot. Alleen respondenten die in 2011 en in 2015 tot werkzame beroepsbevolking behoorden. Onder 'zelfstandigen' worden ook meewerkende gezinsleden gerekend, onder 'loondienst' worden ook uitzend-/oproepkrachten gerekend. Exclusief dienstverband 'anders' 
Figuur 4.31 laat verder zien dat iets minder dan twee derde van de afgestudeerden die voor zichzelf werkten in 2011 dat steeds nog doen in 2015, terwijl 3\% van de afgestudeerden die eerst in loondienst werkten inmiddels voor zichzelf is gaan werken.

FIGUUR 4.31 Percentage zelfstandigen in 2015, naar type dienstverband functie in 2011 ( $\mathrm{n}=1796)$

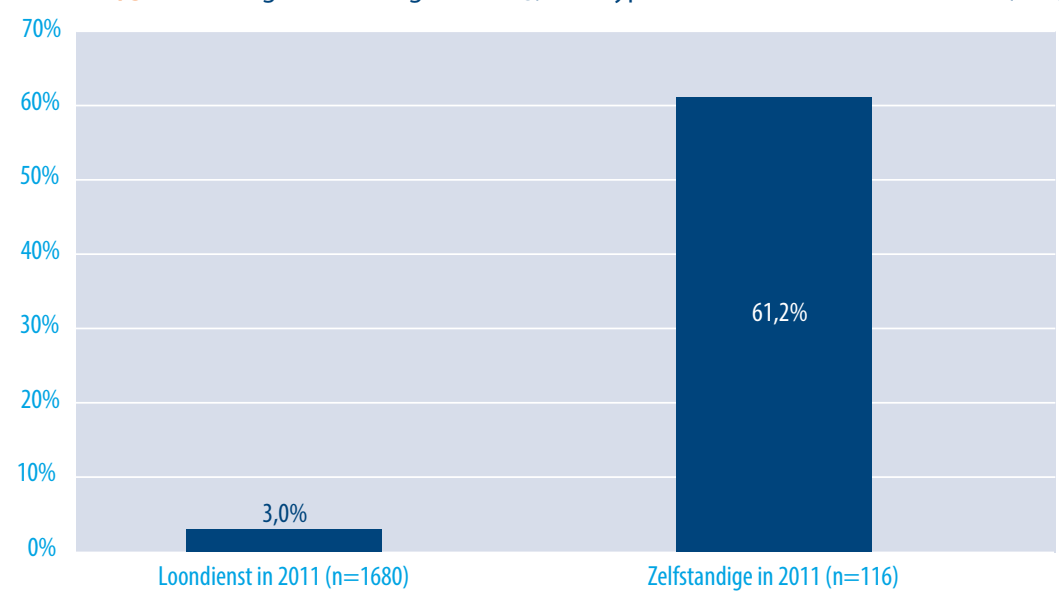

Noot. Alleen respondenten die in 2011 en in 2015 tot werkzame beroepsbevolking behoorden. Onder 'zelfstandigen' worden ook meewerkende gezinsleden gerekend, onder 'loondienst' worden ook uitzend-/oproepkrachten gerekend. Exclusief dienstverband 'anders'.

\subsection{Ontwikkelingen in het hebben van een vaste aanstelling tussen 2011 en 2015}

Uit Figuur 4.32 blijkt dat het aandeel afgestudeerden met een vaste aanstelling fors is toegenomen tussen 2011 en 2015, namelijk bijna een kwart (24\%). Waar minder dan twee derde van de afgestudeerden (62\%) in 2011 een vaste baan had, betreft het in 2015 al bijna negen op de tien (86\%). In 2015 heeft slechts 14\% nog een tijdelijke aanstelling, waarvan de overgrote meerderheid uitzicht heeft op een vaste aanstelling. Uit nadere analyse (niet getoond) volgt dat de toename in het aandeel vaste contracten met name onder voltijdstudenten plaats heeft gevonden (van 52\% naar $84 \%$ ). Onder afgestudeerde deeltijd/duale studenten was het percentage vaste contracten reeds in 2011 zeer hoog (85\%) en is slechts licht toegenomen ( $92 \%$ in 2015). De uitgangspositie van voltijdstudenten en deeltijd/duale studenten (veelal werkzaam) is ook zeer verschillend. 
FIGUUR 4.32 Type aanstelling functie, werkzame beroepsbevolking in loondienst in 2011 en 2015 $(\mathrm{n}=1458)$

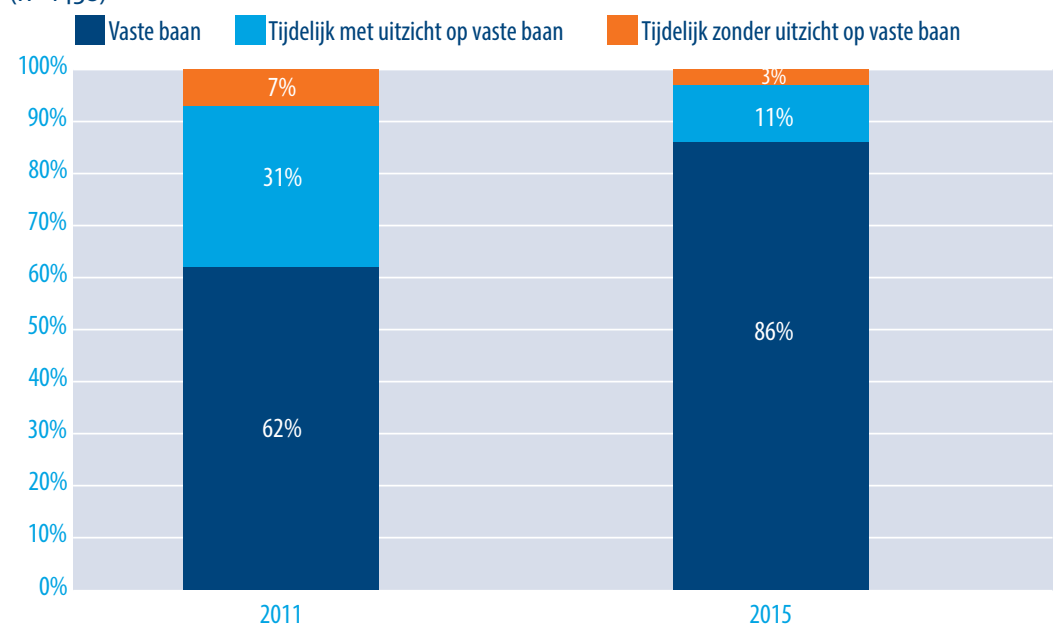

Noot. Alleen respondenten die in 2011 en in 2015 tot werkzame beroepsbevolking in loondienst behoorden, excl. respondenten die aangeven 'n.v.t.'

Als we in Figuur 4.33 kijken naar de ontwikkeling in het aandeel vaste contracten naar sectoren (exclusief Taal \& Cultuur wegens te kleine aantallen in loondienst) dan zien we een structurele en forse toename. In 2011 was het aandeel afgestudeerden met een vast contract voor de hbo-sector Gedrag \& Maatschappij het laagst (43\%), maar in 2015 betrof het reeds een vrij gemiddelde 82 procent. Het grootste aandeel afgestudeerden met een vaste aanstelling vinden we, zowel in 2011 als 2015, in de hbo-sectoren Techniek en Gezondheidszorg. Alles overziend, zijn de verschillen tussen de onderlinge sectoren in 2011 en 2015 niet zo groot.

Uit Figuur 4.34 blijkt dat van degenen die in 2011 geen zicht hadden op een vaste baan, anno 2015 ruim $75 \%$ deze inmiddels wel verkregen heeft. $80 \%$ van de afgestudeerden die in 2011 een tijdelijke aanstelling had met uitzicht op een vaste baan heeft daadwerkelijk een vaste baan in 2015. Tot slot heeft ruim 90\% van degenen die in 2011 reeds een vaste baan hadden deze in 2015 nog steeds. De sterke toename in het aandeel vaste contracten is vrij opmerkelijk. Op zich is het logisch dat de kans op een vast contract toeneemt naarmate men langer werkzaam is bij een werkgever. Tegelijkertijd is de arbeidsmarktsituatie veranderd: zo signaleert het SCP (2013) dat het steeds langer duurt voordat werkenden de transitie van een tijdelijke naar een vaste aanstelling maken. Wilthagen e.a.(2014) stellen dat de flexibilisering van de arbeidsmarkt dan ook haaks staat op de gedachte dat een tijdelijke baan een (snelle) opstap is naar een vaste aanstelling. 
FIGUUR 4.33 Percentage met vaste baan, werkzame beroepsbevolking in loondienst in 2011 en 2015, naar sector, voltijd $(n=1030)$

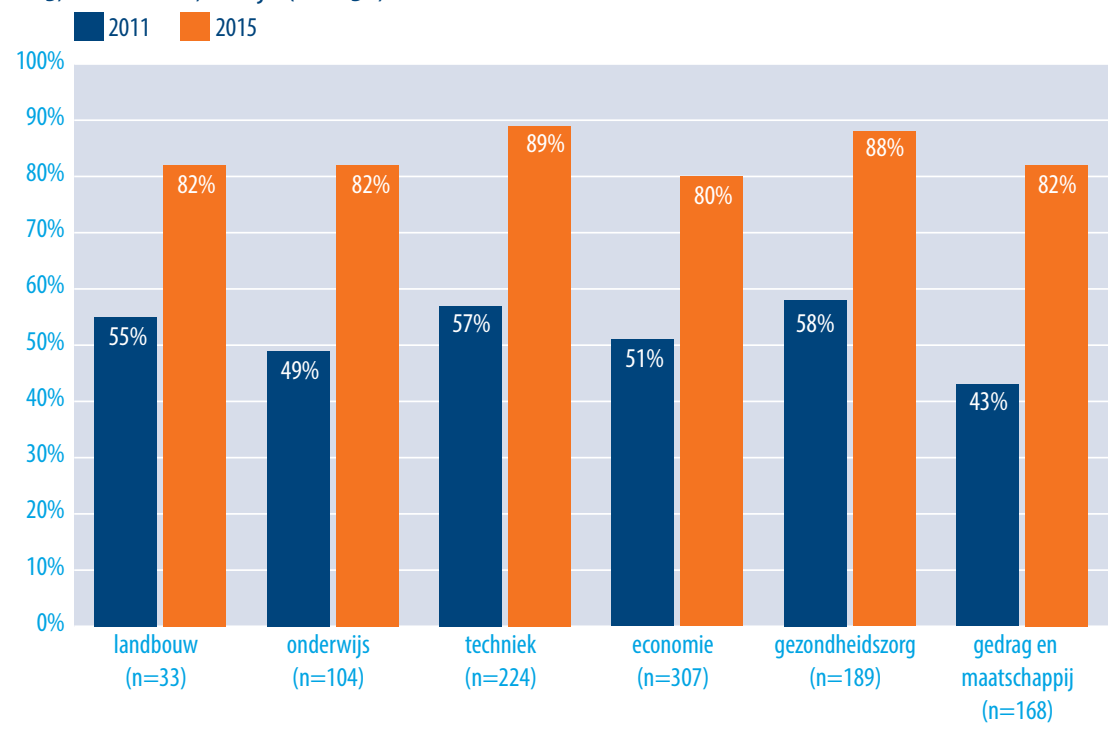

Noot. Alleen respondenten die in 2011 en in 2015 tot werkzame beroepsbevolking in loondienst behoorden, excl. respondenten die aangeven 'n.v.t.. Excl. sector Taal \& Cultuur wegens te kleine aantallen.

FIGUUR 4.34 Type aanstelling functie in 2015, werkzame beroepsbevolking in loondienst, naar aanstelling functie in $2011(n=1458)$

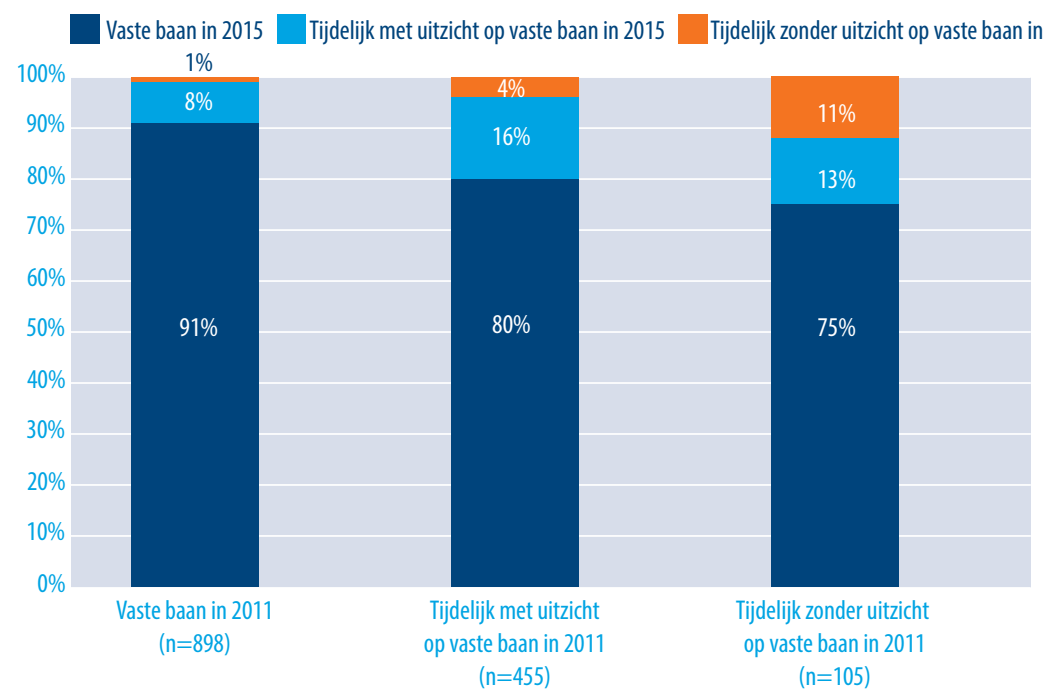

Noot. Alleen respondenten die in 2011 en in 2015 tot werkzame beroepsbevolking in loondienst behoorden, excl. respondenten die aangeven 'n.v.t.' 


\subsection{Ontwikkelingen in bruto uurloon tussen 2011 en 2015}

Zoals verwacht kan worden, zijn de lonen over de hele linie aanzienlijk gestegen tussen 2011 en 2015. Het mediaan reële uurloon is gestegen met $17 \%$ (i.e. gemiddeld $4 \%$ per jaar) van $€ 14,87$ naar $€ 17,31$ (zie Figuur 4.35). In dezelfde periode is de spreiding van de lonen ook licht toegenomen. Uit nadere analyses (hier niet getoond) blijkt dat de stijging sterker is voor afgestudeerden van voltijdopleidingen dan voor afgestudeerden van deeltijd of duale opleidingen, hoewel laatstgenoemde in 2015 nog altijd een loonvoordeel heeft. Zoals Figuur 4.36 laat zien zijn de lonen het sterkste vooruitgegaan in de sectoren Landbouw, Techniek en Economie. In deze sectoren zijn de lonen zowel absoluut als relatief het meest gegroeid.

FIGUUR 4.35 Bruto uurloon in Euro: 10e, 25e, 50e (mediaan), 75e en 9oe percentiel, in 2011 en 2015 $(n=1524)$

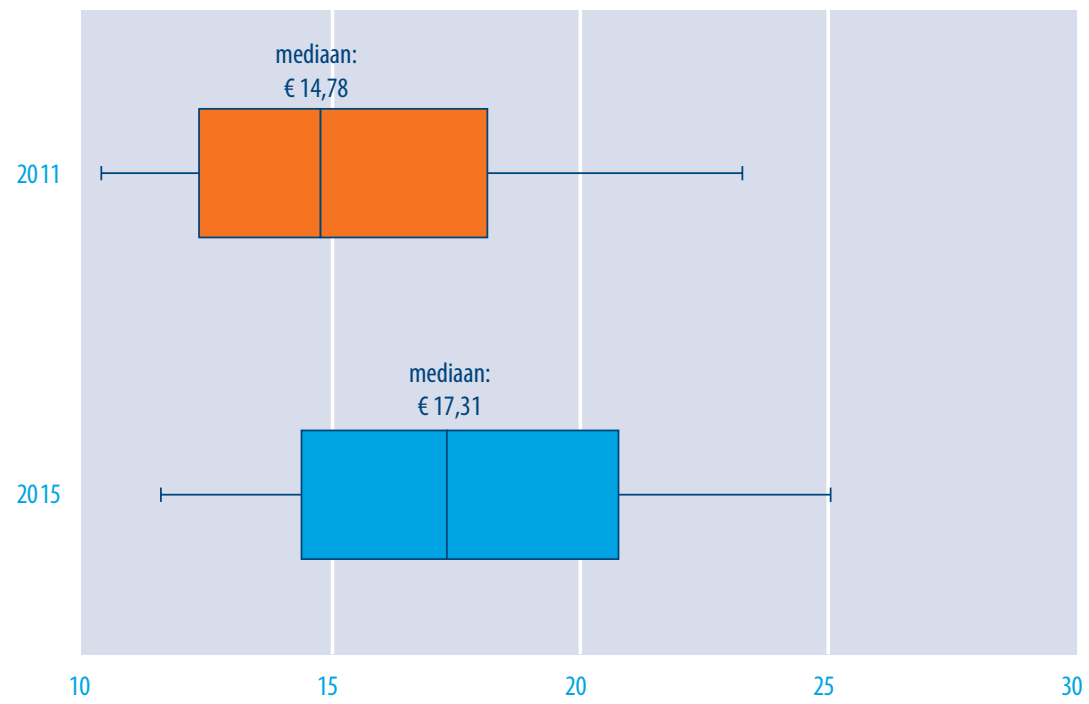

Noot. Alleen respondenten die in 2011 en in 2015 tot werkzame beroepsbevolking behoorden. 


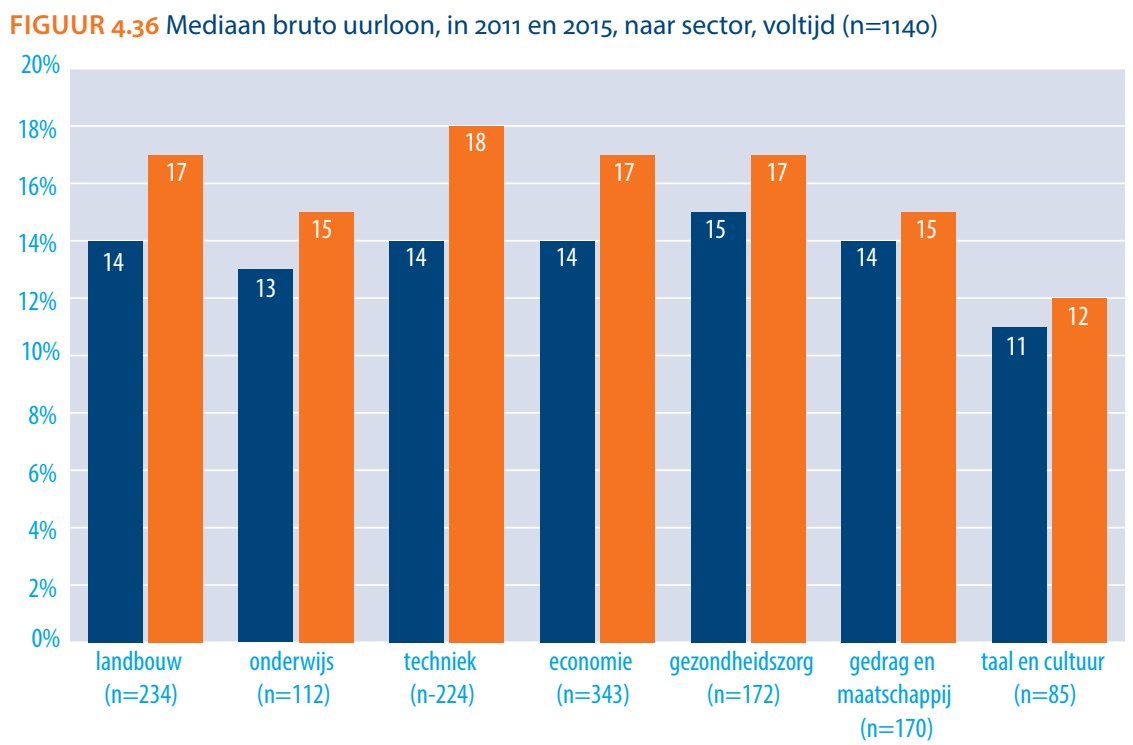

Noot. Alleen respondenten die in 2011 en in 2015 tot werkzame beroepsbevolking behoorden.

Zoals Figuur 4.37 laat zien, blijken afgestudeerden die relatief veel verdienden in 2011 ook vaker goed te verdienen in 2015 dan afgestudeerden die aanvankelijk een lager loon ontvingen. Er is echter veel variatie op beide meetmomenten, waardoor het allesbehalve zeker is dat een relatief hoog of laag loon in 2011 garant staat voor een vergelijkbare positie in de loonverdeling in 2015.

FIGUUR 4.37 Bruto uurloon in Euro in 2011 en 2015 ( $n=946)$

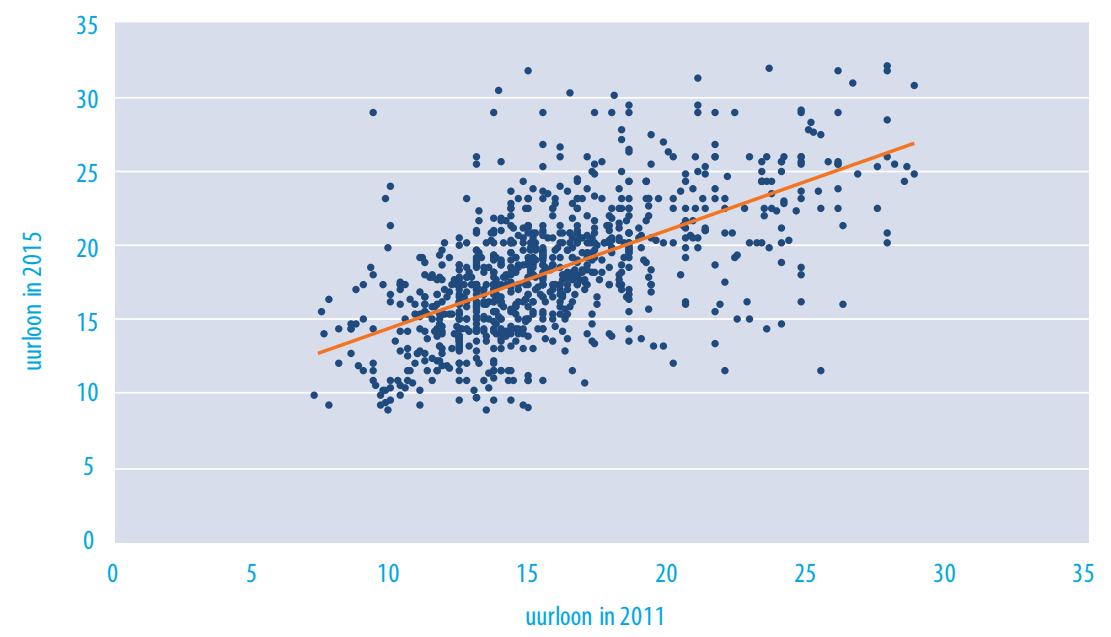

Noot. Alleen respondenten die in 2011 en in 2015 voor minimaal 32 uur per week werkten. 
Een interessante vraag die hiervan in het verlengde ligt, is in hoeverre de loonontwikkeling tussen 2011 en 2015 samenhangt met de beloning in 2011. Is er sprake van een zogenaamde 'Matteüseffect', waarbij de voordelen van een goed begin verder accumuleren naarmate de loopbaan vordert, of is er juist sprake van een vereffening in de loop van de tijd? Figuur 4.38 geeft hiervan een beeld.

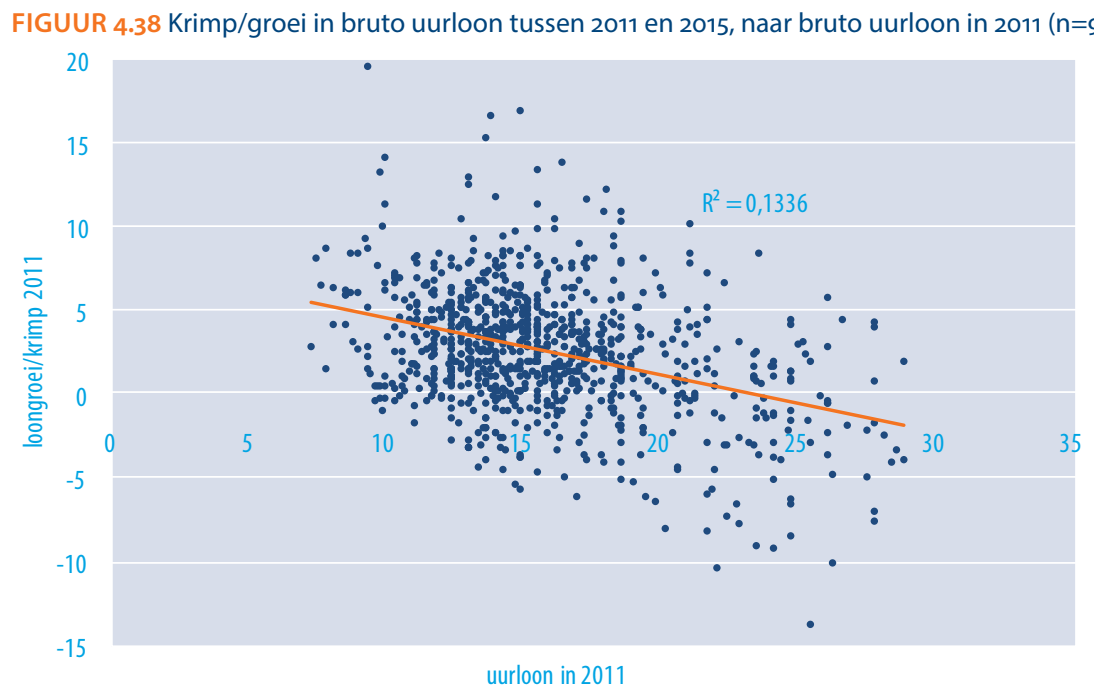

Noot. Alleen respondenten die in 2011 en 2015 voor minimaal 32 uur per week werkten

Uit Figuur 4.38 blijkt dat afgestudeerden die relatief goed verdienen kort na afstuderen geen additioneel voordeel genoten in termen van loongroei in de periode 2011-2015. In tegendeel: de lonen van relatief laagverdieners in 2011 groeiden gemiddeld iets sneller in deze periode dan de lonen van afgestudeerden die in 2011 relatief veel verdienden. Dit verschil was alleen niet genoeg om het initieel voordeel te neutraliseren. 


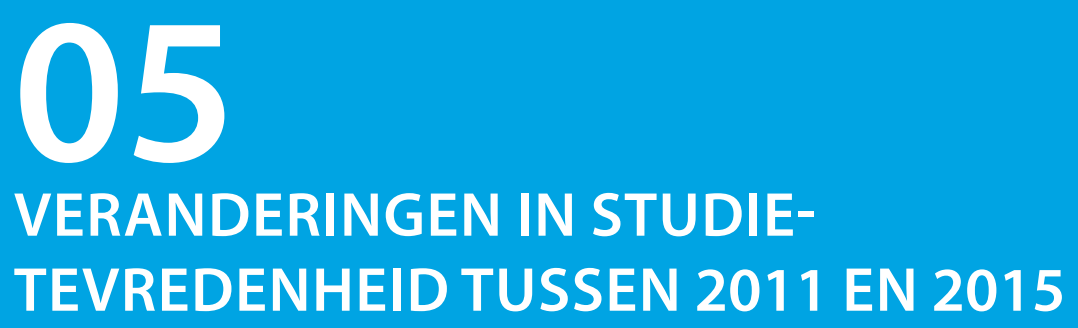

In dit hoofdstuk werpen we een blik op de tevredenheid over de gevolgde opleiding, en met name op in hoeverre het oordeel hierover in de loop van de tijd is veranderd. Het is voor te stellen dat de waardering van afgestudeerden voor hun hbo-opleiding meer reliëf zou kunnen krijgen naarmate men meer ervaring opdoet op de arbeidsmarkt. In 2011 is voor de meeste afgestudeerden immers de hoeveelheid werkervaring waartegen het nut van de opleiding kan worden getoetst beperkt. Aan de andere kant moeten we wellicht rekening houden met het feit dat in de loop van de tijd de tijdens de hbo-opleiding opgedane kennis en ervaringen wat weg kunnen zakken in de herinneringen van afgestudeerden, en voor een deel worden vervangen worden door nieuwe ervaringen op het werk en daarbuiten.

\subsection{Veranderingen in algemene studietevredenheid tussen 2011 en 2015}

Figuur 5.1 toont de mate van algemene studietevredenheid, in 2011 en 2015. Hieruit blijkt dat over de hele linie men iets vaker tevreden is over de opleiding in 2015 dan in 2011. Nadere analyse van de data (Figuur 5.2) laat zien dat vooral afgestudeerden van deeltijd en duale opleidingen meer tevreden worden in de loop van de tijd. Dit is op het eerste gezicht verrassend, we hadden immers verondersteld dat het oordeel zou kunnen worden beïnvloed door werkervaring, en afgestudeerden van deeltijd en duale opleidingen hebben doorgaans meer ervaring kort na het verlaten van de opleiding dan afgestudeerden van voltijd hbo-opleidingen. Wellicht is hun oordeel positiever geworden doordat ze in de loop van de tijd steeds meer de banen die ze tijdens de hbo-opleiding al hadden, inwisselen voor banen die beter passen bij hun capaciteiten. 


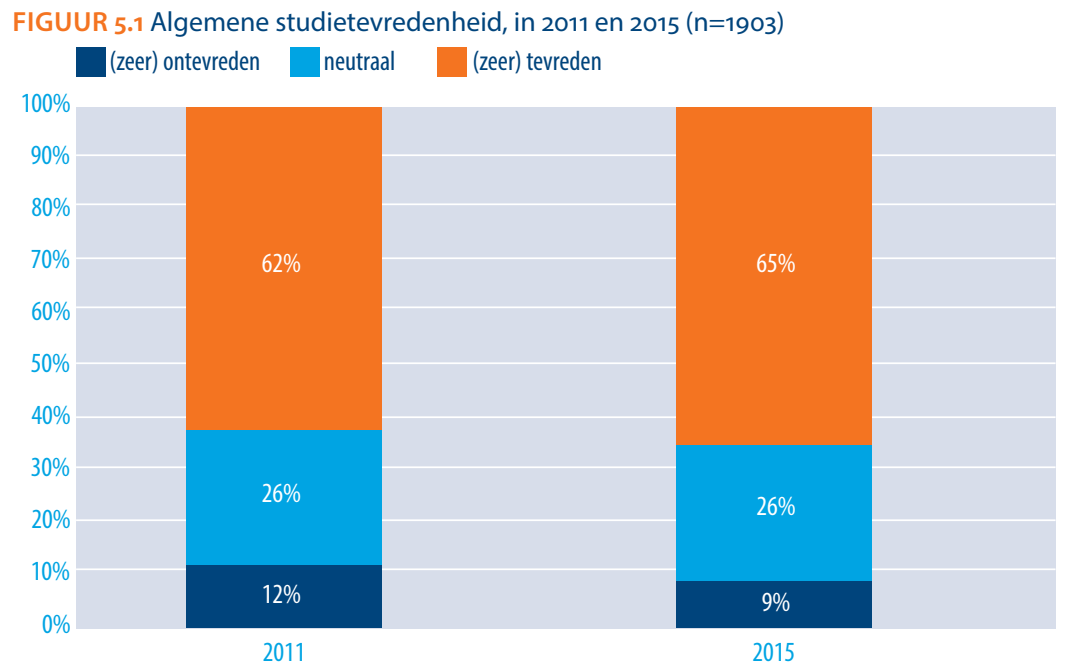

Noot. Exclusief sector Taal \& Cultuur.

FIGUUR 5.2 Percentage dat (zeer) tevreden is over studie in algemeen, in 2011 en 2015, naar voltijd, deeltijd, duaal $(n=1903)$

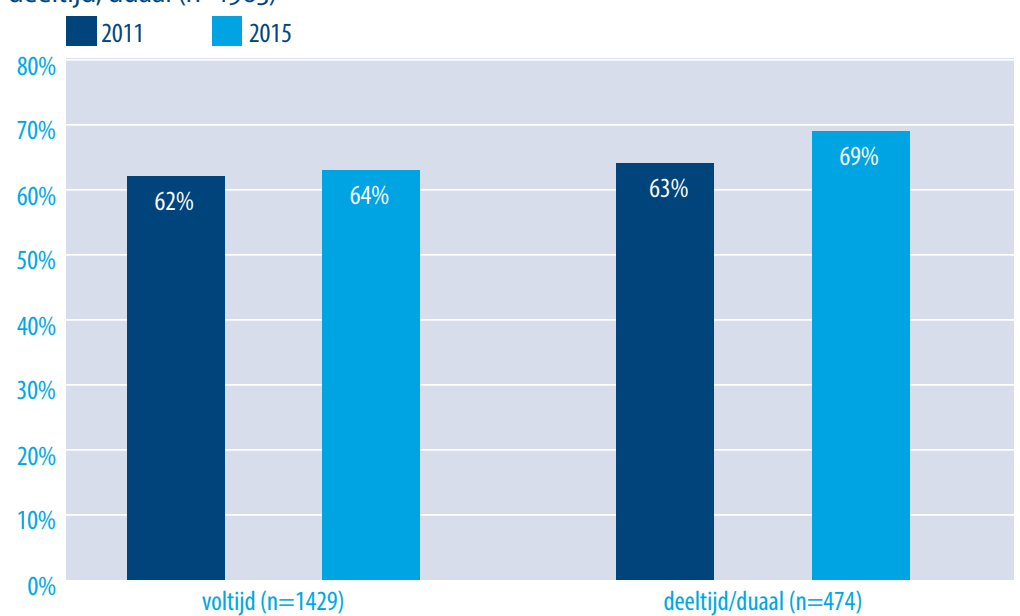

Noot. Exclusief sector Taal \& Cultuur.

Uit Figuur 5.3 blijkt voorts dat vooral afgestudeerden in de sectoren Landbouw en Gezondheidszorg in de loop van de jaren positiever zijn geworden over hun hbo-opleiding. Bij de overige sectoren is relatief weinig veranderd in de algemene tevredenheid over de opleiding. 
FIGUUR 5.3 Percentage dat (zeer) tevreden is over studie in algemeen, in 2011 en 2015, naar sector, voltijd $(n=1423)$

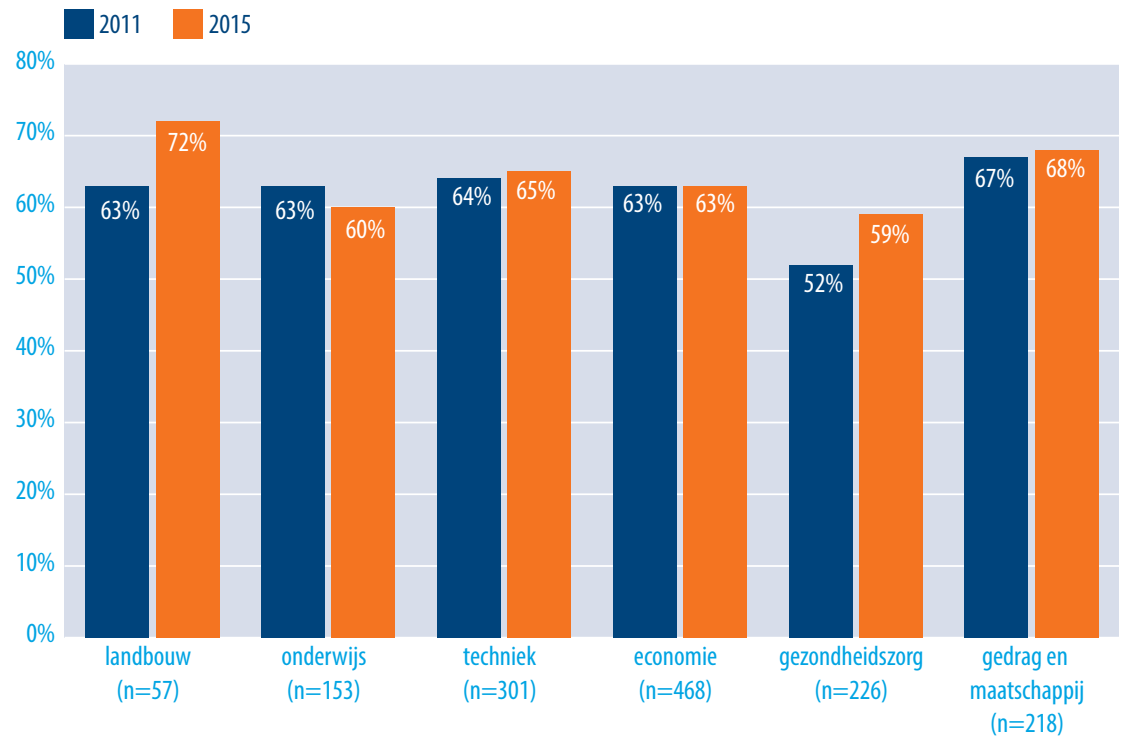

Noot. Exclusief sector Taal \& Cultuur.

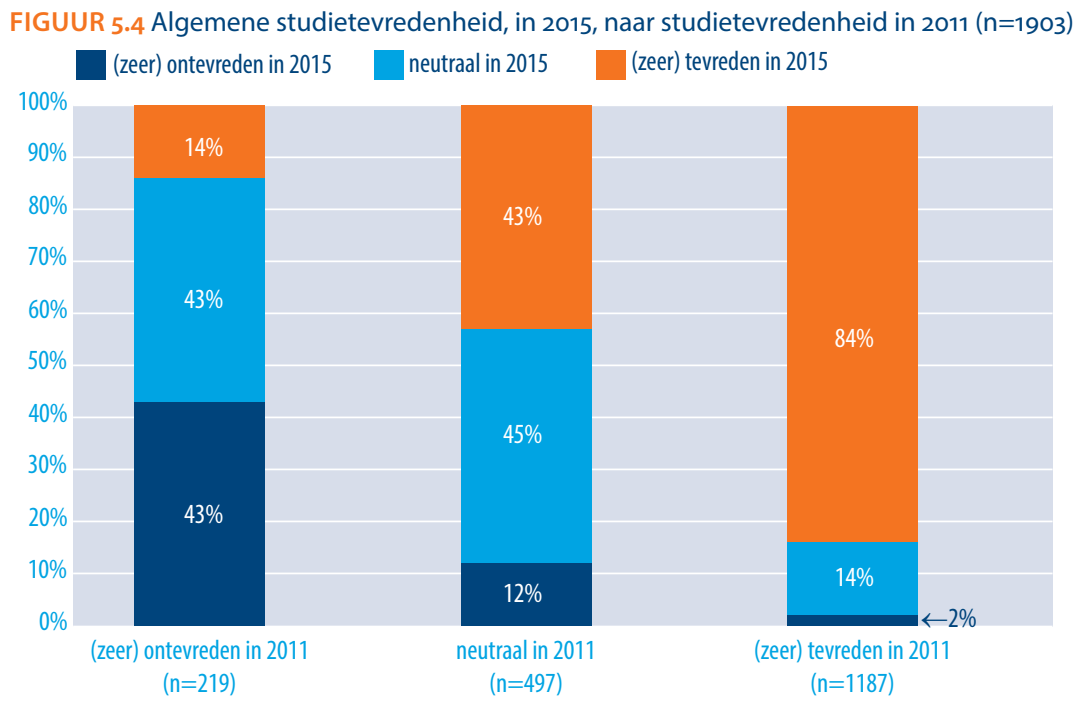

Noot. Exclusief sector Taal \& Cultuur.

Figuur 5.4. toont tot slot dat er sprake is van grote samenhang tussen studietevredenheid in 2011 en 2015: afgestudeerden die in 2011 (zeer) tevreden waren over hun studie zijn hier in 2015 nog steeds beduidend vaker (zeer) tevreden over dan afgestudeerden 
die dat in 2011 niet waren. Echter, tegelijkertijd laat deze figuur zien dat studietevredenheid zeker geen stabiele factor is, en beïnvloedbaar is door ervaringen na de studie. Zo is nog maar $43 \%$ van degenen die (zeer) ontevreden waren over hun studie in 2011 , dit in 2015 nog steeds.

\subsection{Veranderingen in tevredenheid over studie als voorbereiding op verdere loopbaan tussen 2011 en 2015}

Hoewel men in het algemeen tevredener is geworden over de gevolgde opleiding, is op het specifieke punt van de voorbereiding op de (verdere) loopbaan sprake van een lichte daling in de mate van tevredenheid (zie Figuur 5.5). We moeten hierbij wel rekening houden met het feit dat op dit punt het perspectief van de afgestudeerden is veranderd. In 2011 was de afronding van de opleiding nog heel recent, en hadden de meeste afgestudeerden het merendeel van hun loopbaan nog voor de boeg. In 2015 zijn ze inmiddels meer gesetteld in hun loopbaan, en zijn de tijdens de hbo-opleiding opgedane kennis en ervaringen slechts een deel van een veel uitgebreider palet aan competenties waarover ze beschikken. Het is daarom natuurlijk dat de opleiding nu iets minder centraal staat op dit punt dan in het begin van de loopbaan.

FIGUUR 5.5 Tevredenheid over studie ter voorbereiding op (verdere) loopbaan, in 2011 en 2015 $(n=1896)$

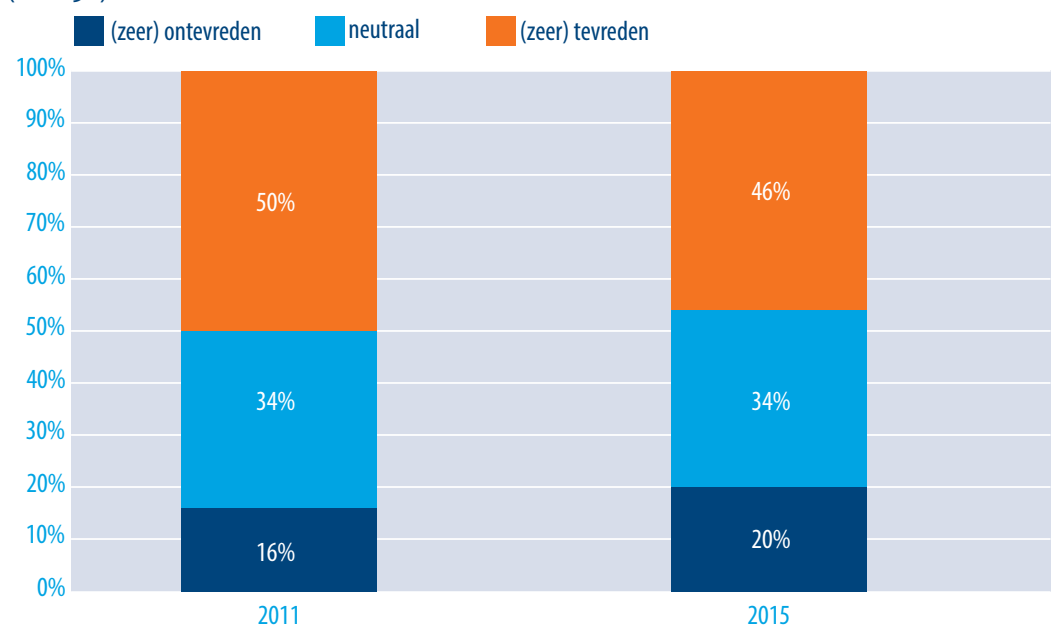

Noot. Exclusief sector Taal \& Cultuur.

Figuur 5.6 laat zien dat er sprake is van een tegengestelde ontwikkeling voor afgestudeerden van voltijd-opleidingen en afgestudeerden van deeltijd en duale opleidingen. Dit zou te maken kunnen hebben met het feit dat afgestudeerden van deeltijd en duale opleidingen vaak een heel andere carrièreontwikkeling doormaken dan afgestudeerden van voltijdopleiding, in de zin dat de opleiding voor hen vaak deel uitmaakt 
van een mobiliteitstraject binnen een beroepsloopbaan dat al vóór de hbo-opleiding is begonnen.

FIGUUR 5.6 Percentage dat (zeer) tevreden is over studie ter voorbereiding op (verdere) loopbaan, in 2011 en 2015, naar voltijd, deeltijd, duaal $(n=1896)$.

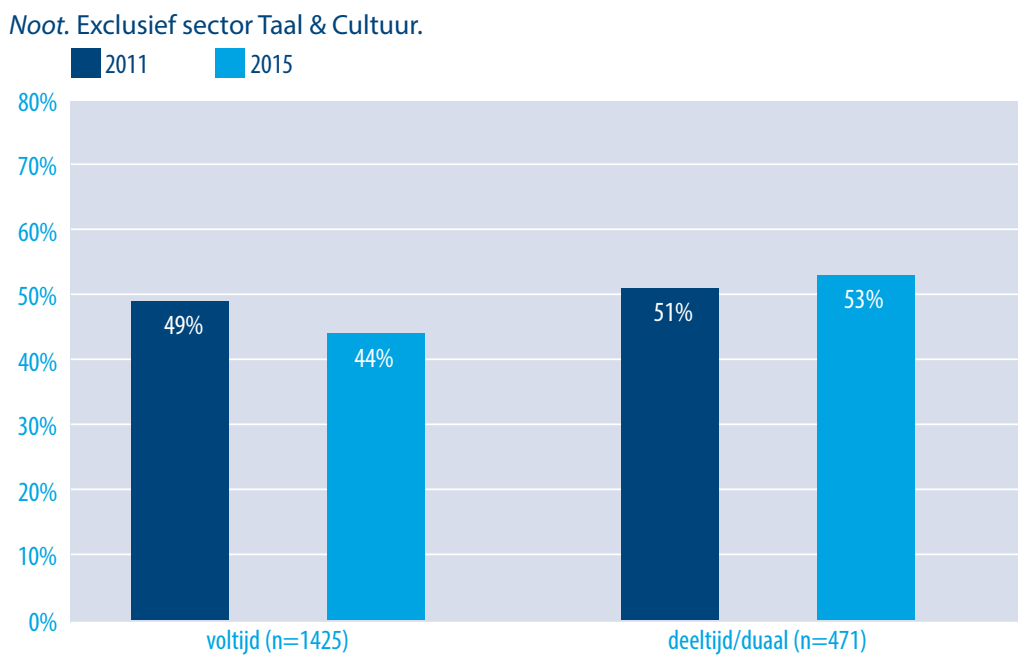

FIGUUR 5.7 Percentage dat (zeer) tevreden is over studie ter voorbereiding op (verdere) loopbaan, in 2011 en 2015, naar sector, voltijd ( $n=1419)$

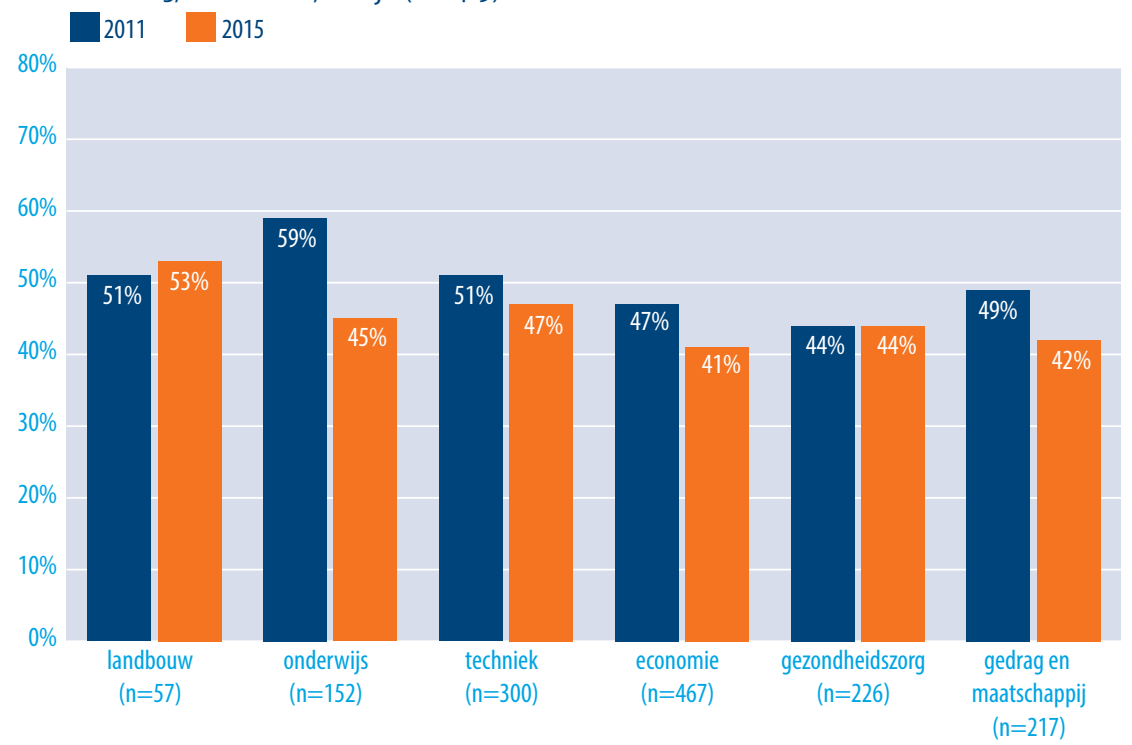

Noot. Exclusief sector Taal \& Cultuur. 
Het is opvallend dat de daling in de tevredenheid over de studie ter voorbereiding op de loopbaan, het sterkste is onder afgestudeerden van de sector Onderwijs (Figuur 5.7). Wellicht hangt dit samen met de beperkte carrièremogelijkheden binnen deze sector (zie Figuur 4.23).

FIGUUR 5.8 Tevredenheid over studie ter voorbereiding op (verdere) loopbaan in 2015, naar tevredenheid in 2011

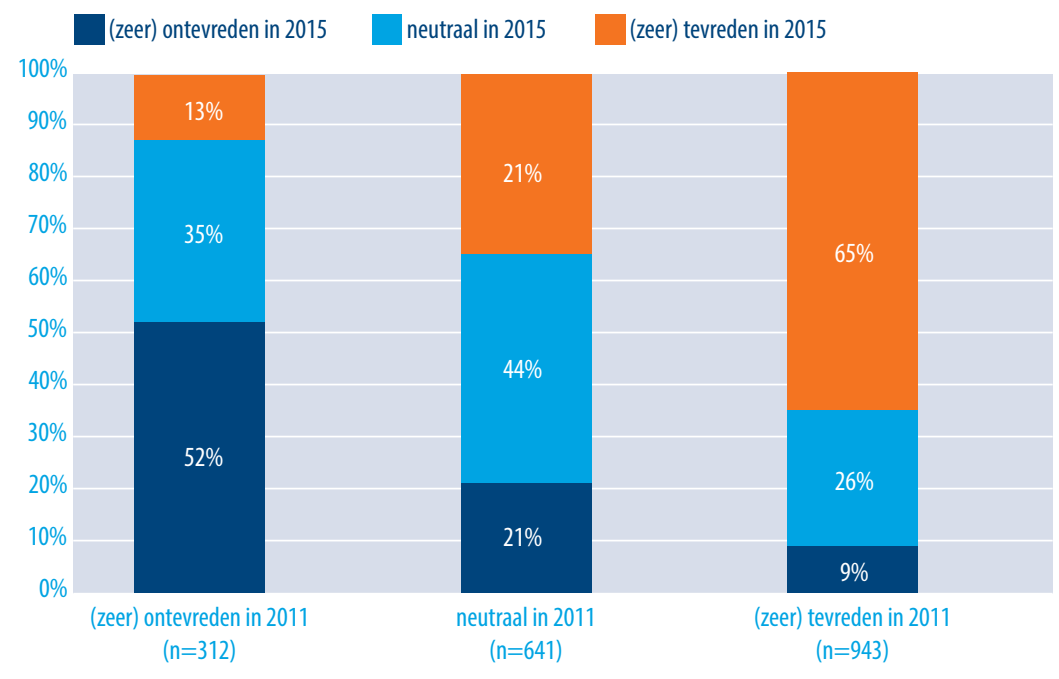

Noot. Exclusief sector Taal \& Cultuur.

Figuur 5.8 toont tot slot dat er sprake is van grote samenhang tussen de mate van tevredenheid over de studie ter voorbereiding op de (verdere) loopbaan in 2011 en 2015: afgestudeerden die in 2011 (zeer) tevreden waren over hun studie ter voorbereiding op (verdere) loopbaan zijn hier in 2015 nog steeds beduidend vaker (zeer) tevreden over dan afgestudeerden dat dat in 2011 niet waren. Wel zijn er ook veranderingen zichtbaar. Zo is nog maar $65 \%$ van degene die (zeer) tevreden waren over hun studie ter voorbereiding op de (verdere) loopbaan in 2011, dit in 2015 nog steeds.

\subsection{Veranderingen in het opnieuw kiezen van de hbo-opleiding tussen 2011 en 2015}

Uit Figuur 5.9 blijkt dat men in 2015 minder vaak opnieuw voor de hbo-opleiding zou kiezen als men weer voor de keuze zou staan, dan in 2011. Met name onder voltijdstudenten is het percentage dat hier weer voor zou kiezen behoorlijk afgenomen (van 81\% naar $75 \%$ ). Dit hoeft niet per se als negatief te worden geïnterpreteerd. Het is immers natuurlijk dat naarmate men ouder wordt, men meer reflecteert op gemaakte keuzes en meer bewust wordt van keuzes die men had kunnen maken. Het feit dat afgestu- 
deerden van deeltijd en duale opleidingen vaker vasthouden aan hun oorspronkelijke positieve oordeel over de gemaakte keuze is consistent hiermee. Deze mensen hebben immers gemiddeld meer werkervaringen achter de rug, en maakten vaker de keuze voor de opleiding op basis van de constatering dat eerder gemaakte keuzes niet optimaal waren. Uit Figuur 5.10 volgt dat de daling in de tevredenheid over de opleidingskeuze sterk geconcentreerd is in de sectoren Economie, Gedrag \& Maatschappij en Taal \& Cultuur.

FIGUUR 5.9 Percentage dat achteraf opnieuw voor de gevolgde hbo-opleiding kiezen, in 2011 en $2015(n=2002)$

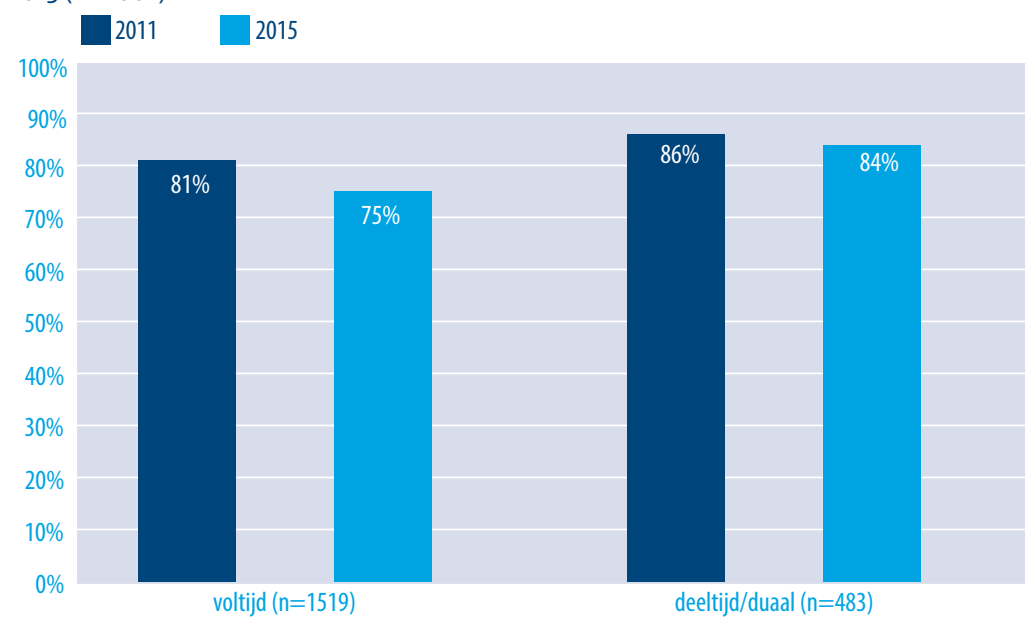

De meest genoemde redenen waarom afgestudeerden niet nogmaals voor dezelfde opleiding zouden kiezen, zijn weergegeven in Figuur 5.11. Het betreffen hier alleen gegevens uit 2015, in 2011 is dit niet bevraagd en derhalve is het niet mogelijk om uitspraken te doen over ontwikkelingen over de tijd. Bijna een derde geeft aan dat de slechte arbeidsmarktperspectieven voor hen de belangrijkste reden zijn om, terugkijkend, niet weer voor de opleiding te hebben gekozen. Andere redenen die relatief vaak als belangrijkst genoemd worden, zijn: 'De opleiding was niet uitdagend genoeg' (voor 13\% de belangrijkste reden) en 'Het curriculum sluit onvoldoende aan bij de huidige beroepspraktijk (12\%). Overigens blijkt voor een groot deel van de respondenten (33\%) een geheel andere reden (dan die in de vragenlijst zijn geopperd) belangrijk te zijn geweest. Er wordt onder andere vaak aangegeven dat men in de loop der tijd andere interesses heeft ontwikkeld. 
FIGUUR 5.10 Percentage dat achteraf opnieuw voor de gevolgde hbo-opleiding kiezen, in 2011 en 2015, naar sector, voltijd $(n=1518)$

2011

2015

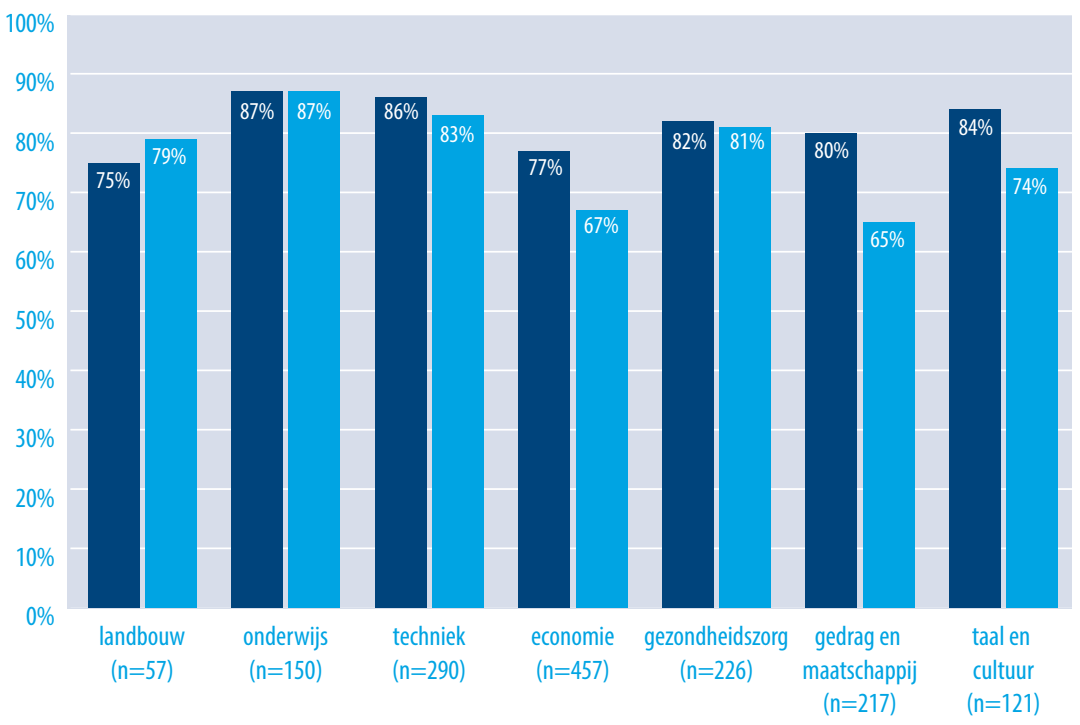

Figuur 5.12 toont tot slot dat er sprake is van grote samenhang tussen de mening over wel of niet opnieuw voor de studie kiezen in 2011 en 2015: afgestudeerden die in 2011 opnieuw voor de door hun gevolgde studie zouden kiezen, zouden dit in 2015 nog steeds beduidend vaker doen dan afgestudeerden die dat in 2011 al niet meer zouden doen. Echter zijn er ook vrij veel afgestudeerden tussen 2011 en 2015 van mening veranderd. Zo is maar liefst 37\% van degenen die in 2011 niet meer voor de studie zouden kiezen terug gekomen op deze mening in 2015.

FIGUUR 5.11 Redenen waarom respondent achteraf niet voor dezelfde opleiding gekozen zou hebben $(n=449)$

De arbeidsmarktperspectieven van de opleiding zijn te slecht

De opleiding was niet uitdagend genoeg
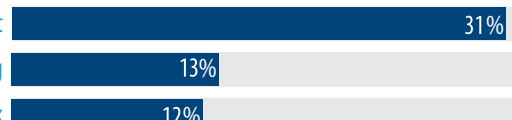

Het curriculum sloot onvoldoende aan bij de huidige beroepspraktijk

De opleiding was slecht georganiseerd

Omstandigheden in de privésfeer $2 \%$

De deskundigheid van de docenten liet te wensen over $2 \%$

Anders

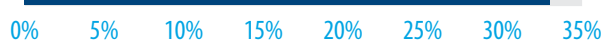


FIGUUR 5.12 Percentage dat opnieuw voor studie zou kiezen in 2015, naar mening hierover in 2011 $(n=2002)$

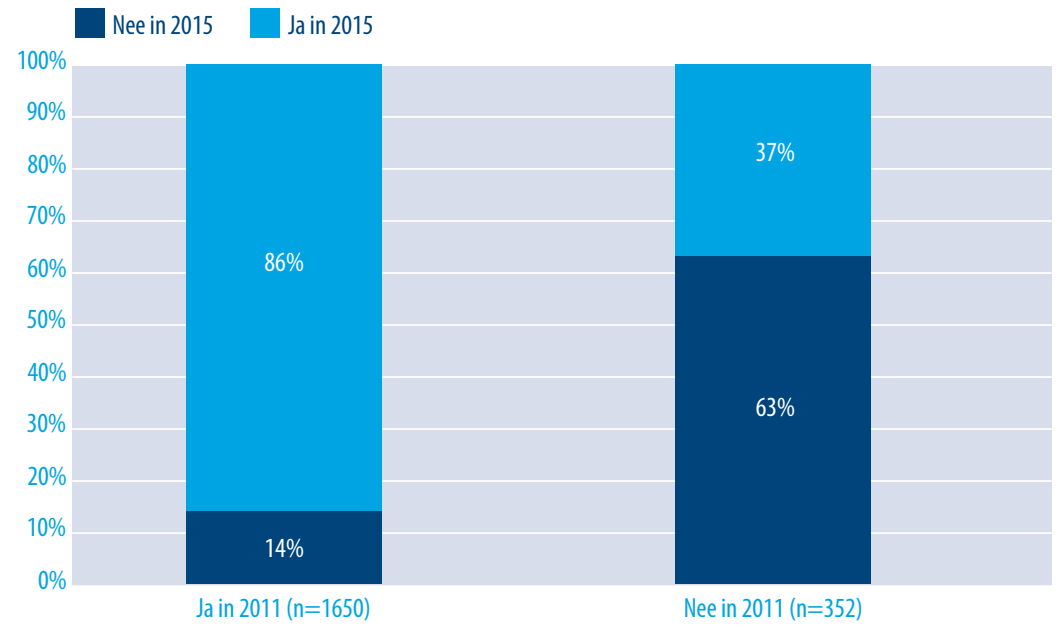





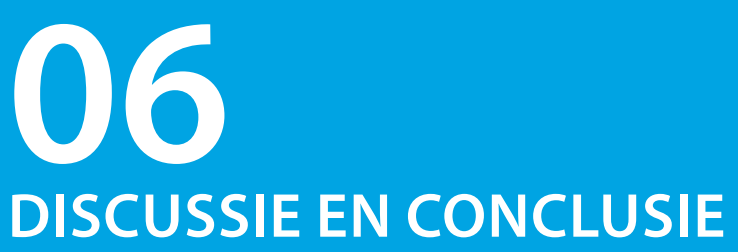

In dit rapport werd de initiële transitie van het hbo naar de arbeidsmarkt in verband gebracht met het verdere verloop van de eerste vijf jaar van de werkcarrière. Hieruit bleek dat de arbeidsmarktsituatie kort na afstuderen weliswaar een effect kan hebben op de manier waarop de carrière zich verder ontwikkelt, maar dat de beginsituatie beslist geen keurslijf is waaruit men niet kan ontsnappen. Een wat stroeve arbeidsmarktintrede heeft immers in de meeste gevallen geen al te grote gevolgen voor de verdere loopbaan. Ruim de helft van afgestudeerden die een jaar na het verlaten van de opleiding werkloos was, of een baan bekleedde waarvoor geen hbo-opleiding was vereist, werkte vier jaar later wel in een baan op hbo-niveau. Dit is consistent met de wachtkamerhypothese: de verwachting dat het soms een aantal jaren kan duren na de initiële transitie naar de arbeidsmarkt voordat men doorgroeit naar het soort werk waarvoor ze opgeleid zijn (Asselberghs e.a. 1998).

Tegelijkertijd vinden we indicaties voor lange 'naweeën' van een stroef begin van de loopbaan (Nilson en Reiso, 2011). Van de afgestudeerden die in 2011 werkloos waren, is $14 \%$ dat in 2015 nog steeds, en relatief veel afgestudeerden die hun loopbanen begonnen in banen onder het eigen niveau en/of buiten de eigen richting, zijn vier jaar later nog niet doorgestroomd naar passend werk. Ook wat betreft andere arbeidsmarktuitkomsten zien we een soortgelijke dualiteit, waarbij een stroeve arbeidsmarktintrede soms zijn sporen naliet en soms niet. Zo bleken afgestudeerden die relatief veel verdienden in 2011 weliswaar vaker goed te verdienen in 2015 dan afgestudeerden die aanvankelijk een lager loon ontvingen, maar geen additionele loongroei te vertonen in de periode 2011-2015. In tegendeel: de lonen van relatief laagverdieners in 2011 groeiden gemiddeld iets sneller in deze periode dan de lonen van afgestudeerden die in 2011 relatief veel verdienden. Dit verschil was alleen niet genoeg om het initieel voordeel te neutraliseren.

Flexibiliteit op de arbeidsmarkt, in de vorm van een tijdelijk contract in de eerste baan, blijkt ook meestal niet al te nadelig te hebben uitgepakt. Zo is het aandeel afgestudeerden met een vaste aanstelling fors toegenomen tussen 2011 en 2015 (van 62\% naar $86 \%)$. Onder degenen die in 2011 nog géén zicht hadden op een vaste baan, heeft ruim 75\% deze in 2015 inmiddels toch verkregen. De werkzekerheid bij deze groep is wel een stuk lager dan bij afgestudeerden die al in 2011 een vaste aanstelling hadden. Van deze laatste groep heeft ruim 90\% nog altijd een vaste aanstelling in 2015 . Over de hele linie bleek relatief weinig sprake van externe mobiliteit in termen van verandering van werk- 
gever. Slechts een op de drie afgestudeerden is meer dan één keer van werkgever veranderd in de periode 2011-2015. De externe baanmobiliteit blijkt het grootst te zijn onder afgestudeerden uit de hbo-sector Taal \& Cultuur en het laagst onder afgestudeerden uit de hbo sectoren Techniek en Landbouw. Mobiliteit tussen beroepsgroepen vindt vooral plaats vanuit de 'dienstverlenende beroepen' (het betreft hierbij in veel gevallen beroepen op mbo-niveau). Minder dan drie op de tien afgestudeerden die in 2011 in deze beroepsgroep actief was, is dit in 2015 nog steeds. Deze beweging is ook consistent met de bovengenoemde wachtkamerhypothese, waarbij afgestudeerden pas na het opdoen van enige ervaring doorstromen van uitvoerende functies op een lager niveau naar functies die beter bij de gevolgde opleiding passen, en waarbij meer verantwoordelijkheid wordt gedragen. We zien dan ook een toename van bijna 10 procentpunten tussen 2011 en 2015 in het aandeel afgestudeerden dat aan andere medewerkers leiding geeft.

Op het gebied van competentieontwikkeling, zien we verdere indicaties voor een toenemende match tussen de capaciteiten van afgestudeerden en de vereisten van de baan. Zo hebben in 2015 beduidend minder afgestudeerden tekorten en overschotten aan 'vakkennis' in vergelijking tot 2011. Op dit gebied is dus sprake van een sterk verbeterde match tussen de persoonlijke competenties van de afgestudeerde en vereiste competenties voor de baan. Bij andere competenties ('logisch redeneren', 'werken conform budget, planning, richtlijnen' en 'ideeën en oplossingen bedenken') is er vooral een afname te zien in het aandeel tekorten. Hieruit blijkt het belang van werkervaring als aanvulling op de opleiding om competenties op het gewenste peil te brengen voor het werk dat moet worden gedaan. Het aandeel overschotten is bij deze meer generieke competenties echter niet afgenomen. Blijkbaar is het niet zo gemakkelijk om door middel van bijvoorbeeld baanmobiliteit of taakaanpassing meer ruimte te creëren voor het gebruik van deze competenties dan bij 'vakkennis'.

Gezien het feit dat over de gehele linie de werksituatie van afgestudeerden aanzienlijk is verbeterd tussen 2011 en 2015, is het opvallend dat de baantevredenheid per saldo licht is afgenomen in dezelfde periode. Het aandeel respondenten dat (zeer) tevreden was met de baan in zijn geheel, daalde met 4 procentpunten tussen 2011 en 2015. Deze daling is het sterkst in de sectoren Landbouw (-15\%) en Gezondheidszorg (-13\%). Afgestudeerden van de sector Economie zijn daarentegen juist iets tevredener in 2015 dan in $2011(+7 \%)$. Het percentage afgestudeerden dat (zeer) tevreden is over de hboopleiding is tussen 2011 en 2015 licht toegenomen (+3\%). Vooral afgestudeerden in de hbo-sectoren Landbouw (+9\%) en Gezondheidszorg (+7\%) zijn in de loop van de jaren positiever geworden. Bij de overige sectoren is weinig veranderd. Hoewel men in het algemeen tevredener is geworden over de gevolgde opleiding, is op het specifieke punt van de voorbereiding op de (verdere) loopbaan juist sprake van een lichte daling in de mate van tevredenheid. Deze daling blijkt het sterkst in de hbo-sector Onderwijs (-15\%). In 2015 zouden minder afgestudeerden dan in 2011 wederom voor hun hbo-opleiding kiezen als ze weer voor de keuze zouden staan (-6\%). De belangrijkste redenen waarom ze hier niet meer voor zouden kiezen, hebben betrekking op de arbeidsmarktperspec- 
tieven van de opleiding, de uitdaging die de opleiding bood, en de aansluiting van het curriculum bij de huidige beroepspraktijk.

Zoals al in de inleiding is opgemerkt, geeft dit rapport slechts een eerste algemene indruk van de resultaten van dit onderzoek. Hoewel we in staat zijn om de resultaten in brede zin te duiden, valt er veel meer over te zeggen, met name in termen van de redenen waarom sommige afgestudeerden veel vooruitgang boeken, en anderen veel minder of helemaal niet. Ligt dit bijvoorbeeld aan kenmerken van de gevolgde hboopleiding, aan additionele ervaringen die vóór, tijdens of ná deze opleiding zijn opgedaan, of aan de gevolgde vooropleiding of eventuele vervolgopleiding die men heeft gevolgd? Loopt de carrière anders bij vrouwen dan bij mannen, bij kinderen van hoogopgeleide ouders dan bij kinderen van laagopgeleide ouders, of bij afgestudeerden met een migratieachtergrond dan bij afgestudeerden wiens wortels volledig in Nederland liggen? En zo ja, in hoeverre heeft dit te maken met verschillen in voorkeuren, hulpbronnen of restricties die anders over verschillende deelpopulaties worden verdeeld? Door middel van een reeks verdiepende rapporten zal in de komende maanden worden getracht op deze en andere vragen een antwoord te geven. 



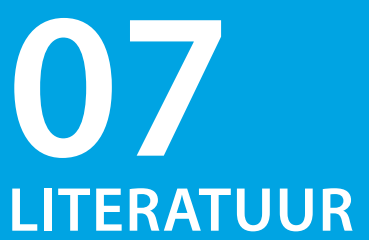

Akyeampong, E. B. (1992). Discouraged workers - where have they gone? Perspectives on Labour and Income. 3. Canada: Statistics Canada. 4 (Article 5).

Allen, J., J. Coenen en R. van der Velden (2007), Afgestudeerden van het hoger onderwijs in Nederland in vergelijking met andere landen: Resultaten van het REFLEX Project, Ministerie van Onderwijs, Cultuur en Wetenschappen, Beleidsgerichte studies Hoger Onderwijs en Wetenschappelijk Onderzoek, 128, Zoetermeer.

Allen, J. \& Velden, R. van der (2001). Educational mismatches versus skills mismatches: effects on wages, job satisfaction, and on-the-job-search. Oxford Economic Papers, Vol. 53, No. 3, pp. 434-452.

Asselberghs, K., R. Batenburg, F. Huijgen en M. de Witte (1998) De kwalitatieve stuctuur van de werkgelegenheid in Nederland, Deel IV, s'Gravenhage: OSA.

Becker, G.S. Human capital. Second edition. New York: Columbia University Press, [1964] 1975.

Beer, J.A.A. de (2012) Crisis in de economie, crisis in relatie- en gezinsvorming? Bevolkingstrends Vol. 12-11-2012.

Borghans, L., Fouarge, D., Grip, A. de \& Thor, J. van (2014). Werken en leren in Nederland. Maastricht: ROA.

Clark, A., Oswald, A., \& Warr, P. (1996). Is job satisfaction U-shaped in age? Journal of occupational and organizational psychology, 69(1), 57-81.

Dekker R. (2014). Het perspectief van jongeren op de Nederlandse arbeidsmarkt. Tilburg: Universiteit van Tilburg.

Estévez-Abe, M., T. Iversen en D. Soskice (2001) Social protection and the formation of skills: a reinterpretation of the welfare state, Varieties of capitalism. The institutional foundations of comparative advantage, Oxford, Volume 145.

Gesthuizen, M. \& Dagevos, J. (2005). Arbeidsmobiliteit in goede banen. Den Haag: SCP.

Gregg, P. (2001). The impact of youth unemployment on adult unemployment in the NCDS. The Economic Journal, 111(475), 626-653.

Heckman, J.J. en C. Pages (2000) The Cost of Job Security Regulation: Evidence from Latin American Labor Markets, NBER Working Paper No. 7773.

Houtman I. (2004) Oorzaken van werkdruk: een onderbelicht thema. Tijdschrift voor arbeidsvraagstukken, 20(1), 90-106

Lam, S.S.K., T.W.H. Ng en D.C. Feldman (2012) The relationship between external job mobility and salary attainment across career stages, Journal of Vocational Behavior, Volume 80, Issue 1, February 2012, Pages 129-136. 
Lazear, E.P. (1990) Job Security Provisions and Employment, The Quarterly Journal of Economics, Vol. 105, No. 3 (Aug., 1990), pp. 699-726.

McCloy, U. en S. Liu (2010), What are the Influencers of Graduate Satisfaction and Labour Market Outcomes of Ontario College Graduates? An Analysis of Ontario's College Graduate Satisfaction Survey Higher Education Quality Council of Ontario.

Mortensen, D. en C. Pissarides (1994). "Job creation and job destruction in the theory of unemployment". Review of Economic Studies. 61 (3): 397-415.

Mroz, T. A., \& Savage, T. H. (2006). The long-term effects of youth unemployment. Journal of Human Resources, 41(2), 259-293

Nilsen, Ø.A. en K.H. Reiso (2011), Scarring Effects of Unemployment, IZA Discussion Paper Series, No. 6198

OECD (2009) OECD Indicators on Employment Protection - update 2009, Paris: OECD Publishing.

Savage T.H. (2006) The long-term effects of youth unemployment. Journal of Human Resources, 41(2), 259-293

Sattinger, M. (2012). Assignment Models and Quantitative Mismatches. Prepared for the Expert Workshop "Skill Mismatch and Firm Dynamics: Integrating Skills with the World of Work," April 27, London.

Schultz, T.W. The economic value of education. New York: Columbia University Press, 1963.

Sicherman, N. en O. Galor (1990) A Theory of Career Mobility, Journal of Political Economy, Vol. 98, No. 1 (Feb., 1990), pp. 169-192.

Smulders, P., \& Houtman, I. (2004). Oorzaken van werkdruk: een onderbelicht thema. Tijdschrift voor Arbeidsvraagstukken, 20(1), 90-106.

Spector, P.E. (1997). Job satisfaction: Application, assessment, causes and consequences. Thousand Oaks, CA: SAGE.

Støren, L. A. en C.Å. Arnesen (2011), Winners and Losers, in: Allen, J. en R. van der Velden, The Flexible Professional in the Knowledge Society: New Challenges for Higher Education.

Theeuwes, J. (2008). De levensloop vanuit economisch perspectief. In M. Mol, H. Dirven \& R. van der Bie (Red.), Dynamiek in de sociale statistiek (pp. 23-32). Voorburg: CBS.

Warr P. (1996) Is job satisfaction U-shaped in age? Journal of occupational and organizational psychology, 69(1), 57-81

Wilthagen, T., Peijen, R., Dekker, R., \& Bekker, S. (2014). Het perspectief van jongeren op de Nederlandse arbeidsmarkt. Tilburg: Universiteit van Tilburg. 